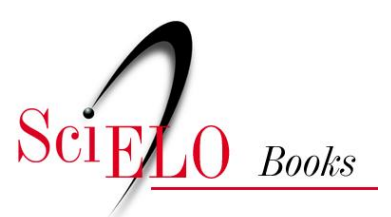

\title{
8. Vetores conhecidos no Brasil
}

\author{
Cleber Galvão \\ Rodrigo Gurgel-Gonçalves
}

GALVÃO, C., and GURGEL-GONÇALVES, R. Vetores conhecidos no Brasil. In: GALVÃO, C., org. Vetores da doença de chagas no Brasil [online]. Curitiba: Sociedade Brasileira de Zoologia, 2014, pp. 88-170. Zoologia: guias e manuais de identificação series. ISBN 978-85-98203-09-6.

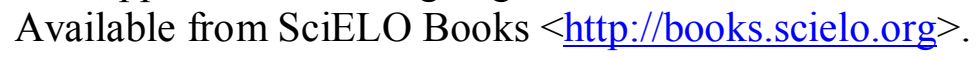

\section{(c) (1) @(2)}

All the contents of this chapter, except where otherwise noted, is licensed under a Creative Commons Attribution-Non Commercial-ShareAlike 3.0 Unported.

Todo o conteúdo deste capítulo, exceto quando houver ressalva, é publicado sob a licença Creative Commons Atribuição Uso Não Comercial - Partilha nos Mesmos Termos 3.0 Não adaptada.

Todo el contenido de este capítulo, excepto donde se indique lo contrario, está bajo licencia de la licencia Creative Commons Reconocimento-NoComercial-CompartirIgual 3.0 Unported. 


\title{
8. Vetores conhecidos no Brasil
}

\author{
(Cleber Galvão \& Rodrigo Gurgel-Gonçalves)
}

"A área de disseminação parece cobrir todo o paiz, possuindo o Instituto exemplares provindos dos confins da Guiana Ingleza, de Minas, S. Paulo, Mato Grosso e Goiaz e tendo ainda informações, que Ihe denunciam a prezença nos estados de Sergipe, Piaui e Pernambuco."

(Arthur Neiva, 1910)

Dos 18 gêneros de barbeiros conhecidos, dez possuem representantes no Brasil e até o momento 65 das 148 espécies conhecidas foram encontradas no território nacional (Figura 8.1). Ao longo do capítulo, ilustrado com fotos coloridas, são apresentadas as características morfológicas gerais, a etimologia, as sinonímias, os principais habitats, a distribuição geográfica (estados de ocorrência, limites da distribuição conhecida e distribuição potencial) e em alguns casos curiosidades sobre cada uma dessas espécies.

As descrições completas da maioria das espécies estão incluídas na obra de Lent \& Wygodzinsky (1979), entretanto, para as espécies descritas após esse ano é preciso consultar as publicações originais. Informações mais detalhadas sobre habitat e fauna relacionada podem ser obtidas em Carcavallo et al. (1998).

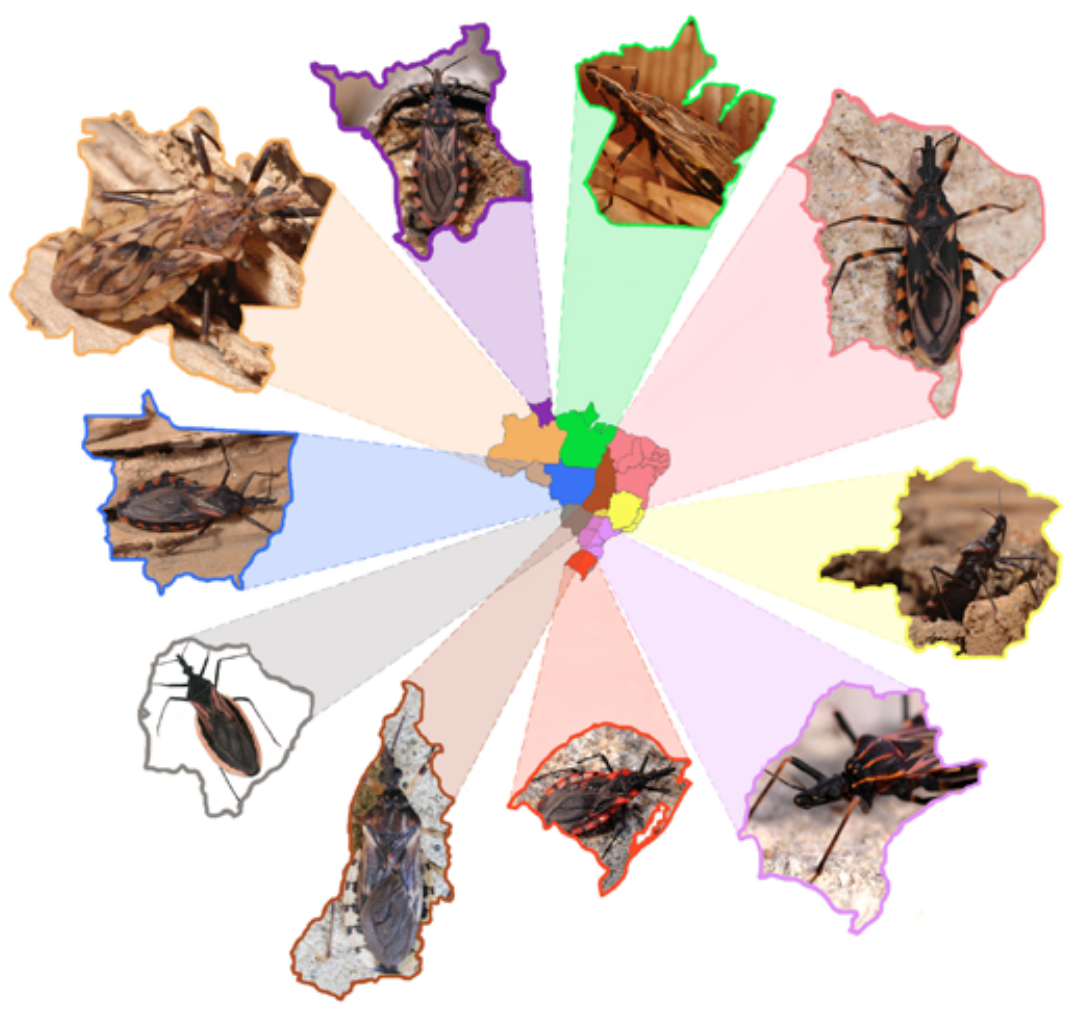

Figura 8.1: Exemplos de espécies ocorrentes em diferentes regiões, estados ou grupos de estados do Brasil. A partir do Estado do Pará, no sentido horário: Rhodnius pictipes, Triatoma brasiliensis, $T$. vitticeps, T. tibiamaculata, T. rubrovaria, T. sordida, T. baratai, $T$. guazu, Panstrongylus lignarius e T. maculata.

Com exceção de Alberprosenia malheiroi, Belminus laportei, Microtriatoma trinidadensis, Panstrongylus diasi, P. lenti, Parabelminus yurupucu, Rhodnius amazonicus, Tritoma baratai, T. jatai e T. pintodiasi todas as demais espécies já foram encontradas naturalmente infectadas por tripanosomatídeos no Brasil. Panstrongylus megistus), constituindo um dos primeiros registros de ocorrência de triatomíneos em estados brasileiros. 
O estudo da distribuição geográfica de triatomíneos é fundamental para a compreensão de aspectos epidemiológicos relacionados à transmissão do Trypanosoma cruzi e deve ser considerado para orientar as ações de vigilância e controle da doença de Chagas. Com esse objetivo Silveira et al. (1984) mapearam a distribuição geográfica de 30 espécies de triatomíneos capturados em ambiente domiciliar no Brasil (com exceção de São Paulo e região amazônica), sendo um estudo pioneiro e até hoje usado como referência em análises geográficas por pesquisadores interessados em vigilância da doença de Chagas no Brasil. Entretanto, após 29 anos, novas espécies foram descritas, novos registros de espécies conhecidas foram relatados e estudos em áreas não avaliadas por Silveira et al. (1984) foram realizados, principalmente na região amazônica. Além disso, o padrão de transmissão da doença de Chagas tem mudado após o controle do Triatoma infestans, que foi a principal espécie domiciliada. Nesse cenário, com o aumento da relevância da infecção por via oral e da transmissão extra-domiciliar por triatomíneos nativos, há a necessidade de melhorar, atualizar e refinar a distribuição geográfica dos vetores conhecidos no Brasil.

Neste capítulo foram incluídas as 32 espécies de triatomíneos não analisadas no estudo de Silveira et al. (1984) e utilizados métodos de análise geográfica baseados em variáveis ecológicas, não considerados nos mapas produzidos por Carcavallo et al. (1999). Apresenta-se o mapeamento geográfico das 65 espécies de triatomíneos que ocorrem no Brasil, incluindo limites da distribuição conhecida e a distribuição potencial, que pode ser predita usando a modelagem de nicho ecológico. Essa abordagem tem sido usada nos últimos anos para analisar a distribuição geográfica de triatomíneos e vem produzindo bons resultados (Costa et al. 2002, Gorla 2002, Peterson et al. 2002, López-Cárdenas et al. 2005, Sandoval-Ruiz et al. 2008, Gurgel-Gonçalves \& Cuba 2009, Gurgel-Gonçalves \& Silva, 2009, Arboleda et al. 2009, Ibarra-Cerdeña et al. 2009, Batista \& Gurgel-Gonçalves, 2009).

A modelagem da distribuição geográfica potencial é baseada no conceito de nicho ecológico, um conjunto de condições (bióticas e abióticas) necessárias para a manutenção de populações de uma espécie (Grinnell 1917). Na modelagem de nicho ecológico, são utilizados pontos de ocorrência da espécie obtidos em museus, coleções particulares e registros georreferenciados. A partir dos valores de latitude e longitude de cada ponto de ocorrência é possível acessar as características ecológicas locais (valores de temperatura, precipitação, altitude, cobertura vegetal) e relacionar com as característi-

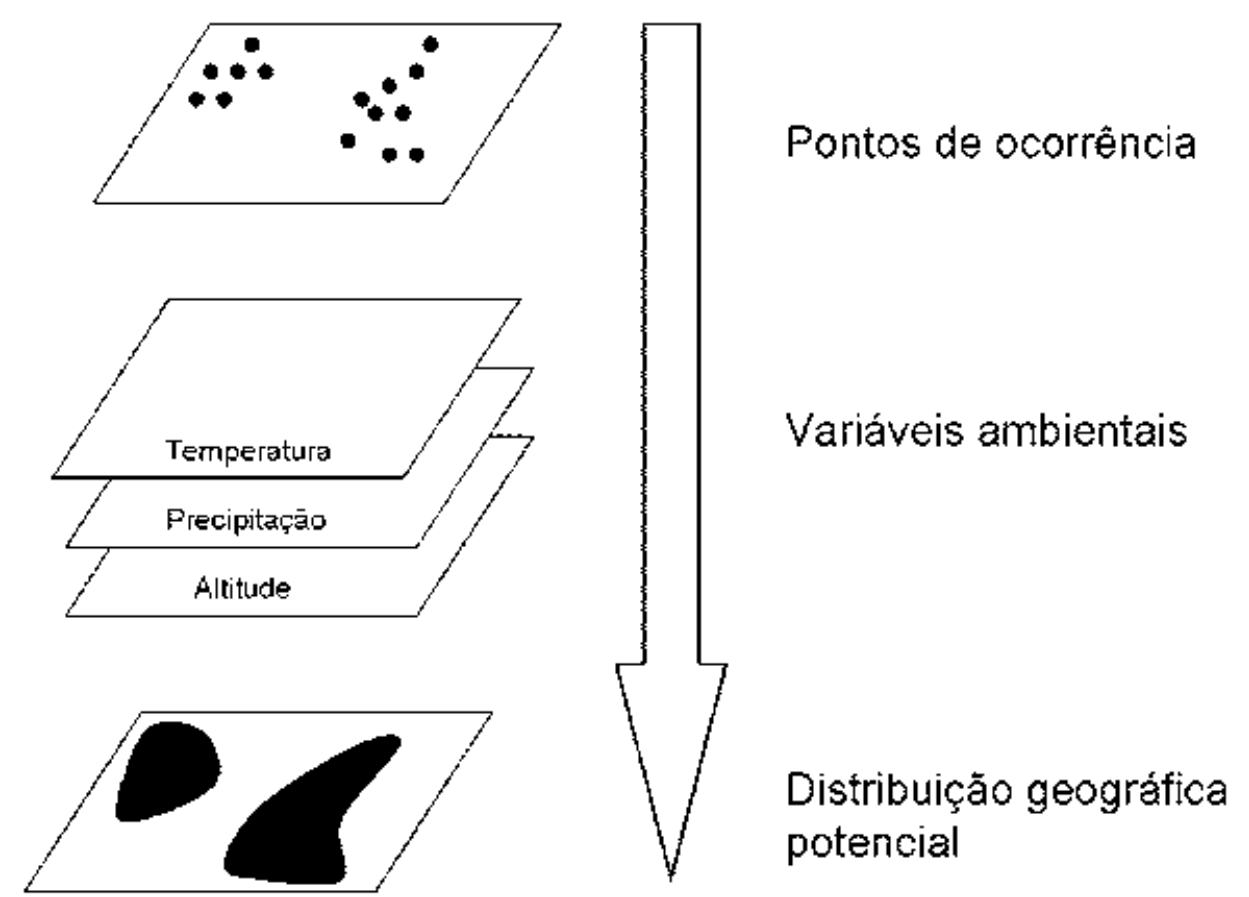

Figura 8.2: Esquema mostrando os elementos básicos da modelagem de nicho ecológico. 
cas ecológicas de toda área de estudo, obtidas a partir de bases de dados ambientais disponíveis. A partir da aplicação de algoritmos ou modelos matemáticos há a definição dos limites ecológicos de distribuição que são usados na produção dos mapas de distribuição potencial (Figura 8.2). Vários métodos podem ser utilizados para predizer a distribuição geográfica potencial de espécies utilizando modelagem de nicho ecológico baseados em pontos de ocorrência e análise de variáveis ambientais. Essa modelagem representa uma aproximação de nicho ecológico da espécie, não considerando barreiras geográficas e interações bióticas como competição e predação (Anderson et al. 2003). Entretanto, a comparação entre a distribuição potencial e a conhecida permite levantar hipóteses sobre fatores históricos, barreiras geográficas e interações que inviabilizam a ocorrência das espécies em áreas com condições ecológicas favoráveis. Esses modelos também possibilitam prever efeitos de variações climáticas em determinadas espécies e, no caso de vetores, permite prever áreas de risco de transmissão de patógenos.

A maioria dos registros de ocorrência das espécies de triatomíneos no Brasil foi obtida em Lent \& Wygodzinsky (1979), Silveira et al. (1984), Carcavallo et al. (1985), Carcavallo et al. (1999). Novos registros foram obtidos em Luitgards-Moura et al. (2005), Leite et al. (2007), Oliveira et al. (2007), Almeida et al. (2008), Massaro et al. (2008), Abad-Franch et al. (2009), Carbajal de la Fuente et al. 2009, Gurgel-Gonçalves \& Cuba (2009), Gurgel-Gonçalves \& Silva (2009), Pavan (2009) e descrições de espécies após 1999 (Carcavallo \& Jurberg 2000, Carcavallo et al. 2001, Papa et al. 2002, Costa et al. 2006, Costa \& Felix 2007, Jurberg et al. 2009, 2013, Rosa et al. 2012, Gonçalves et al. 2013). Foram analisados também os registros das coleções Rodolfo Carcavallo e Herman Lent do Laboratório Nacional e Internacional de Referência em Taxonomia de Triatomíneos do Instituto Oswaldo Cruz, FIOCRUZ e informações das Secretarias Estaduais de Saúde, principalmente da Bahia, Pará, Pernambuco, São Paulo e Tocantins. No caso de estudos que descreveram apenas os nomes das localidades, as coordenadas geográficas (longitude e latitude da sede da localidade) foram obtidas usando a base de dados do IBGE (http://www.ibge.gov.br).

Os mapas de distribuição geográfica potencial foram produzidos usando o algoritmo Maxent (Phillips et al. 2006), que faz previsões ou inferências a partir de informações incompletas. Os modelos foram construídos somente para as espécies com mais de 10 registros de ocorrência. Vinte variáveis foram usadas para construção dos modelos no Maxent, entre elas altitude, valores de temperatura (p. ex: média diurna, máxima, mínima, anual, trimestral) e precipitação (p. ex: media anual, máxima, mínima, trimestral). Essas variáveis foram obtidas do projeto Worldclim (http:// www.worldclim. org/), descritas por Hijmans et al. (2005). Os modelos foram baseados também na distribuição das ecorregiões da América Latina descrita pela WWF-TNC (2001). A base de dados ambientais utilizada nas análises com Maxent cobre todo o território brasileiro apresentando uma resolução espacial de 2,5 minutos ( $5 \times 5 \mathrm{~km}$ por pixel). Para a modelagem de nicho ecológico foram usados os parâmetros pré-definidos do software versão 3.2.1.

Nos mapas produzidos, a adequabilidade ambiental para a ocorrência das espécies de triatomíneos foi indicada por uma escala de vermelho. As áreas em vermelho claro representam menores condições ambientais para a ocorrência da espécie enquanto as áreas em vermelho-escuro mostram alta adequabilidade ambiental. As linhas pontilhadas indicam os limites da distribuição geográfica conhecida das espécies. Para as espécies com menos de 10 registros de ocorrência foram mantidos os pontos de ocorrência em vermelho. Em alguns casos de registros muito distantes dos 
limites de ocorrência conhecidos também foram mantidos os pontos vermelhos no mapa. Abaixo algumas considerações sobre a distribuição geográfica de algumas espécies.

Apesar de R. prolixus já ter sido registrado no Brasil (Silveira et al. 1984, Diotaiuti et al. 1984, Pinho et al. 1998) estudos recentes usando morfometria geométrica, sistemática molecular e biogeografia (Abad-Franch \& Monteiro 2007, Gurgel-Gonçalves et al. 2008, Abad-Franch et al. 2009) mostram que essa espécie ocorre somente ao norte da Amazônia e os registros no Brasil podem ter sido erros de identificação, já que $R$. prolixus é muito similar a $R$. robustus sendo difícil a distinção. Os registros de $R$. prolixus feitos pelas Secretarias Estaduais de Saúde da região Centro-Oeste e Nordeste também devem ter sido erros de identificação em relação a $R$. neglectus e $R$. nasutus, respectivamente. O único registro de $R$. prolixus no Rio de Janeiro pode ter sido acidental, já que a espécie nunca mais foi capturada neste estado, muito distante geograficamente da área principal de ocorrência de populações silvestres de $R$. prolixus na Venezuela. A ausência de $R$. prolixus no Brasil central tem um significado epidemiológico importante já que esta espécie apresenta grande potencial de domiciliação, sendo muito frequente em casas em sua área de ocorrência, e portanto, responsável pela transmissão vetorial da doença de Chagas em vários países da América Latina (Gurgel-Gonçalves et al. 2008).

Estudos recentes de sistemática molecular têm detectado espécies crípticas em $R$. robustus (Monteiro et al. 2003), T. brasiliensis (Monteiro et al. 2004) e R. pictipes (Pavan 2009). No complexo T. brasiliensis duas espécies foram descritas (T. juazeirensis e T. melanica) e seus mapas foram incluídos no presente trabalho. No caso dos complexos $R$. robustus e $R$. pictipes mantivemos a distribuição conhecida atribuída a cada táxon, sem considerar diferenças geográficas entre as linhagens detectadas.

Algumas espécies de triatomíneos apresentam distribuição geográfica muito ampla no Brasil. Uma das explicações para esse padrão seria a capacidade de dispersão passiva por animais que têm grande potencial de dispersão, como pássaros (p. ex: furnarídeos no caso de $P$. tertius e $R$. neglectus), mamíferos voadores (p. ex: morcegos no caso de C. pilosa), e terrestres (gambás e tatus no caso de $P$. megistus e $P$. geniculatus). A dispersão pode ser facilitada pelo mecanismo de aderência dos ovos ao substrato (p. ex: penas), já demonstrado para várias espécies, principalmente as da tribo Rhodniini. Outro mecanismo possível seria transporte de ninfas entre as penas. Um das evidências desse tipo de dispersão é a coincidência entre a distribuição de algumas espécies de Rhodnius como R. neglectus e pássaros como Phacellodomus ruber (graveteiro) e Pseudoseisura cristata (casaca de couro) (Gurgel-Gonçalves \& Cuba 2009). Em alguns casos a distribuição ampla pode ser atribuída à dispersão passiva pelo transporte marítimo, como no caso de T. rubrofasciata.

A maioria das espécies de triatomíneos no Brasil apresenta distribuição geográfica mais restrita, com poucos registros em determinadas ecorregiões, principalmente na região amazônica, como por exemplo, A. malheiroi e R. amazonicus. Entre os fatores que explicam esse padrão estariam: a) são espécies estritamente silvestres e de difícil detecção e b) a região amazônica ainda não foi bem amostrada em relação à fauna de triatomíneos, apesar de alguns estudos terem sido feitos nos últimos anos (p. ex: Abad-Franch \& Monteiro 2007). Em outros casos, os poucos registros de ocorrência são devido ao fato da espécie ter sido descrita recentemente, como no caso de $R$. milesi, R. montenegrensis, T. baratai, T. jatai, T. klugi, T. pintodiasi e T. vandae. 
Analisando os padrões de diversidade observa-se que 42 das 65 espécies registradas (64\%) só ocorrem no Brasil. A Bahia é o estado com maior riqueza de espécies (23) seguido do Mato Grosso (20). Os estados com menor número de espécies registradas são Acre, Amapá e Rondônia (Tabela 8.1). Agrupando as espécies por bioma de ocorrência principal (mais de 50\% das ocorrências) observamos que a maioria das espécies habita os biomas Cerrado e Amazônia (Figura 8.3). A distribuição geográfica de algumas espécies coincide fortemente com a distribuição do bioma,

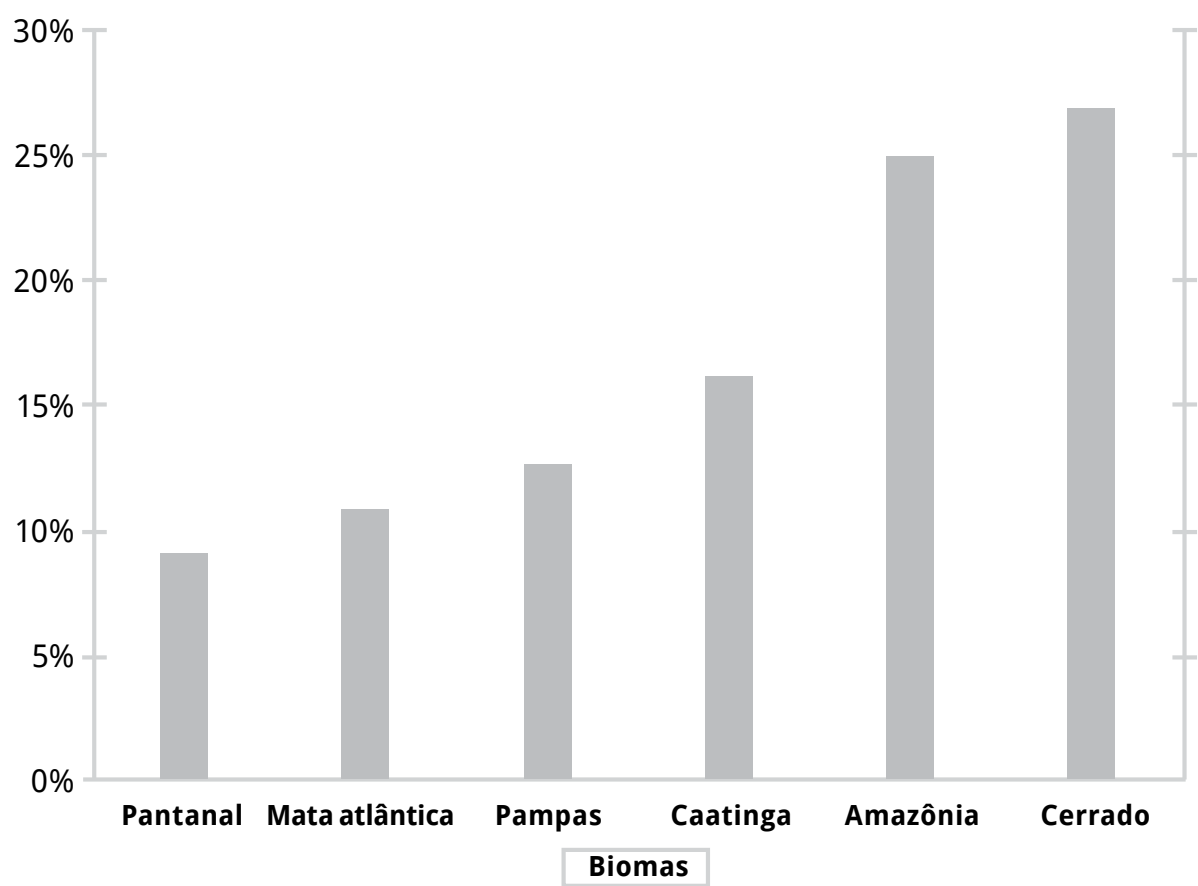

Figura 8.3: Riqueza relativa das espécies de triatomíneos nos biomas brasileiros.

como é o caso de $R$. neglectus e $T$. sordida com o Cerrado, $R$. nasutus e $P$. lutzi com a Caatinga, $R$. robustus e $R$. pictipes com a Amazônia, $R$. domesticus e T. tibiamaculata com a Mata Atlântica, T. rubrovaria e $P$. tupynambai com os Pampas e, finalmente, $T$. baratai e $P$. guentheri com o Pantanal (ver mapas respectivos ao longo do capítulo). Outras espécies como $P$. geniculatus e $P$. megistus ocorreram em mais de 20 estados brasileiros e em pelo menos três biomas, mostrando grande potencial de adaptação a diferentes condições ecológicas. Um dos motivos para a maior riqueza de espécies registrada na Bahia pode ser a variedade de biomas e eco-regiões no estado, incluindo Cerrado, Caatinga e Mata atlântica. Esses padrões de diversidade também indicam os estados nos quais a fauna de triatomíneos precisa ser mais amostrada, principalmente Acre, Amapá e Rondônia. 
Tabela 8.1: Distribuição das 65 espécies de triatomíneos conhecidas nas 27 unidades da federação do Brasil. A última linha indica o total de espécies registradas na unidade da federação e a última coluna indica o número total.

Espécies

Alberprosenia malheroi

Belminus laportei

Cavernicola lenti

C. pilosa

Eratyrus mucronatus

Microtriatoma borbai

M. trinidadensis

Panstrongylus diasi

$P$. geniculatus

P. guentheri

P. lenti

$P$. lignarius

P. lutzi

P. megistus

P. rufotuberculatus

P. tupynambai

Parabelminus carioca

$P$. yurupucu

Psammolestes coreodes

P. tertius

Rhodnius amazonicus

R. brethesi

$R$. domesticus

R. milesi

$R$. montenegrensis

$R$. nasutus

R. neglectus

$R$. paraensis

R. pictipes

$R$. robustus

$R$. stali

R. zeledoni

Triatoma arthurneivai

T. baratai

T. brasiliensis

T. carcavalloi

T. circummaculata

T. costalimai

T. deaneorum

T. delpontei

T. guazu

T. infestans

T. jatai

T. juazeirensis

T. jurbergi

T. klugi

T. lenti

T. maculata

T. matogrossensis

T. melanica

T. melanocephala

T. oliveirai

T. petrocchiae

T. pintodiasi

T. platensis

T. pseudomaculata

T. rubrofasciata

T. rubrovaria

T. sherlocki

T. sordida

T. tibiamaculata

T. vandae

$T$. vitticeps

T. williami

T. wygodzinsky

Total \begin{tabular}{|l|l|l|l|l|l|l|l|l|l|l|l|l|l|l|l|l|l|l|l|l|l|l|l|l|l|l|l|}
\hline AC & AL & AM & AP & BA & CE & DF & ES & GO & MA & MG & MS & MT & PA & PB & PE & PI & PR & RJ & RN & RO & RR & RS & SE & SP & SC & TO & Total \\
\hline
\end{tabular}
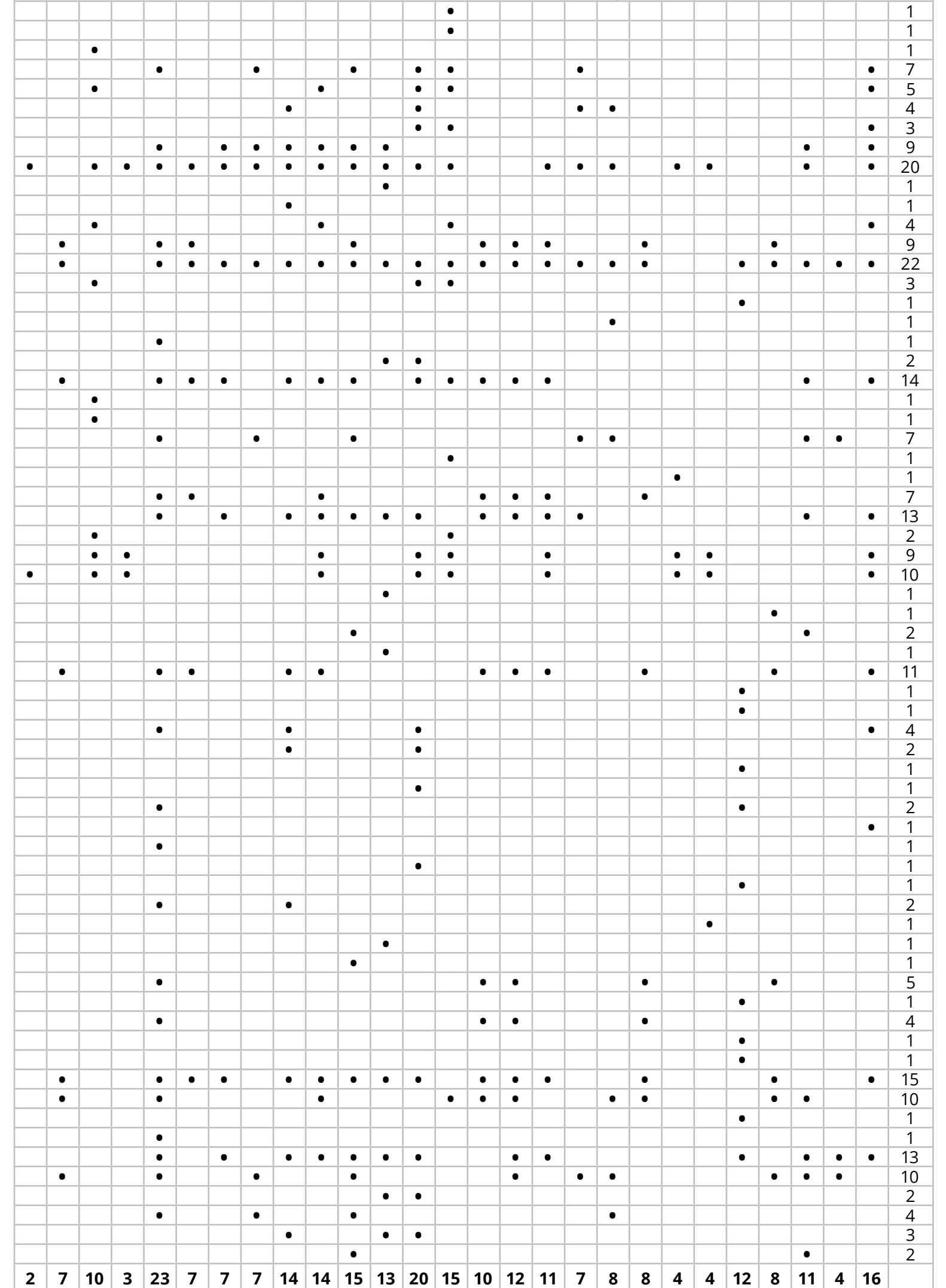


\section{Alberprosenia malheiroi Serra, Atzingen \& Serra, 1987}

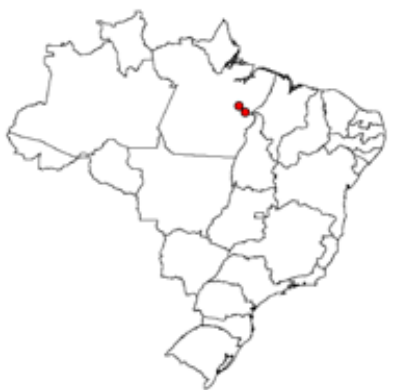

Etimologia: O nome genérico Alberprosenia é uma homenagem a Alberto F. Prosen, entomólogo Argentino.

Características gerais: Comprimento total dos machos de 7,9 a 8,2 mm, das fêmeas de 8,0 a $8,3 \mathrm{~mm}$. Coloração geral marrom escuro com pilosidade castanho escura. Hemiélitro de coloração mais clara, com mancha amarela em forma de triângulo. Cabeça de comprimento similar à largura na região dos olhos. Região inter-ocular maior que a largura de um olho em vista dorsal. Região anteocular de comprimento quase igual a pós-ocular. Olhos grandes, globosos. Ocelos grandes, bem visíveis. Genas curtas apenas alcançando o bordo do clípeo. Tubérculos anteníferos inseridos imediatamente adiante dos olhos. Proporções entre os artículos antenais =1:2,5:2,7:3.1. Proporções entre os segmentos do rostro $=1: 1,5: 0,5$. Pronoto com superfície rugosa, lóbulo posterior com linha mediana longitudinal e duas carenas laterais que alcançam o bordo posterior. Escutelo com comprimento maior que o pronoto e processo escutelar longo. Pernas de coloração castanho-escuro avermelhado, articulação fêmur-tibial mais clara em todas as pernas. Coxas e trocânteres lisos; fêmures com fileiras de dentículos em todas as pernas. Fossetas esponjosas visíveis nas tíbias anteriores e medianas, tarsos mais claros, quase amarelados. Abdômen com o conexivo sem manchas, uniformemente escuro. Para descrição completa veja Carcavallo et al. (1995).

Material tipo: depositado na Faculdade de Saúde Pública, Universidade de São Paulo.

Habitat: Em tronco oco da palmeira "Bacaba" (Oenocarpus bacaba) associado a morcegos (Pteropterix sp.); em tronco seco da palmeira do "Açaí" (Euterpe oleracea); em ninhos de pica-pau (Picidae) (Carcavallo et al. 1995).

Curiosidades: Esses triatomíneos são ágeis e voam com facilidade. Em laboratório alimentaram-se em morcegos, pombos e humanos, mas recusaram alimentação em rato, camundongo e hamster. O desenvolvimento de ovo a adulto em laboratório durou em média de 132 dias (Carcavallo et al. 1995).

Distribuição: Pará. 


\section{Belminus laportei Lent, Jurberg \& Carcavallo, 1995}

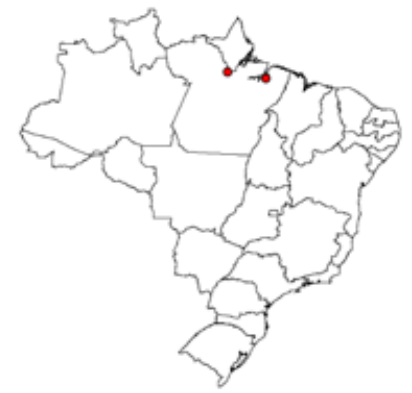

Etimologia: o nome genérico Belminus vem do latim "bel" que significa belo e "minus" que significa pequeno, uma referência a beleza e ao tamanho diminuto desses triatomíneos. $\mathrm{O}$ epíteto específico laportei é uma homenagem a Francis de Laporte (1810-1880), naturalista francês que realizou expedições à América do Sul e foi o criador do gênero Triatoma.

Características gerais: Comprimento total dos machos de 8,5 a 8,9 $\mathrm{mm}$, das fêmeas de 8,2 a 9,4 mm. Coloração geral negra com áreas claras e alaranjadas em diversas regiões do pronoto, abdômen e pernas. Cabeça rugosa e granulosa, 2,8 vezes mais longa que larga ao nível dos olhos e mais longa do que o pronoto (proporção =1:0,7). Clípeo truncado e reto. Região interocular maior que a largura de um olho em vista dorsal (proporção $=1,6: 1$ ). Região anteocular mais longa que a pós-ocular (proporção=1:0,35). Ocelos pequenos. Genas distintamente mais longas que o clípeo. Tubérculos anteníferos sem projeções espinhosas laterais. Rostro atingindo o nível do lobo anterior do pronoto (proporções $=1: 0,7: 0,4$ ). Pronoto com bordos do lobo anterior divergentes, carenas longitudinais não alcançando o bordo posterior do pronoto. Escutelo com processo apical subcilíndrico e alaranjado. Hemiélitros totalmente negros. Pernas com todas as coxas, trocânteres e a maior parte da face ventral dos fêmures de coloração alaranjada. Conexivo com metade de cada segmento alaranjada. Para descrição completa veja Lent et al. (1995). Uma chave dicotômica para identificação de todas as espécies do gênero Belminus foi publicada por Sandoval et al. (2007).

Material tipo: depositado na Coleção Herman Lent do Instituto Oswaldo Cruz, Rio de Janeiro e no Museu Emílio Goeldi, Pará.

Habitat: Desconhecido.

Curiosidades: Única espécie de Belminus encontrada até hoje no território nacional.

Distribuição: Pará.

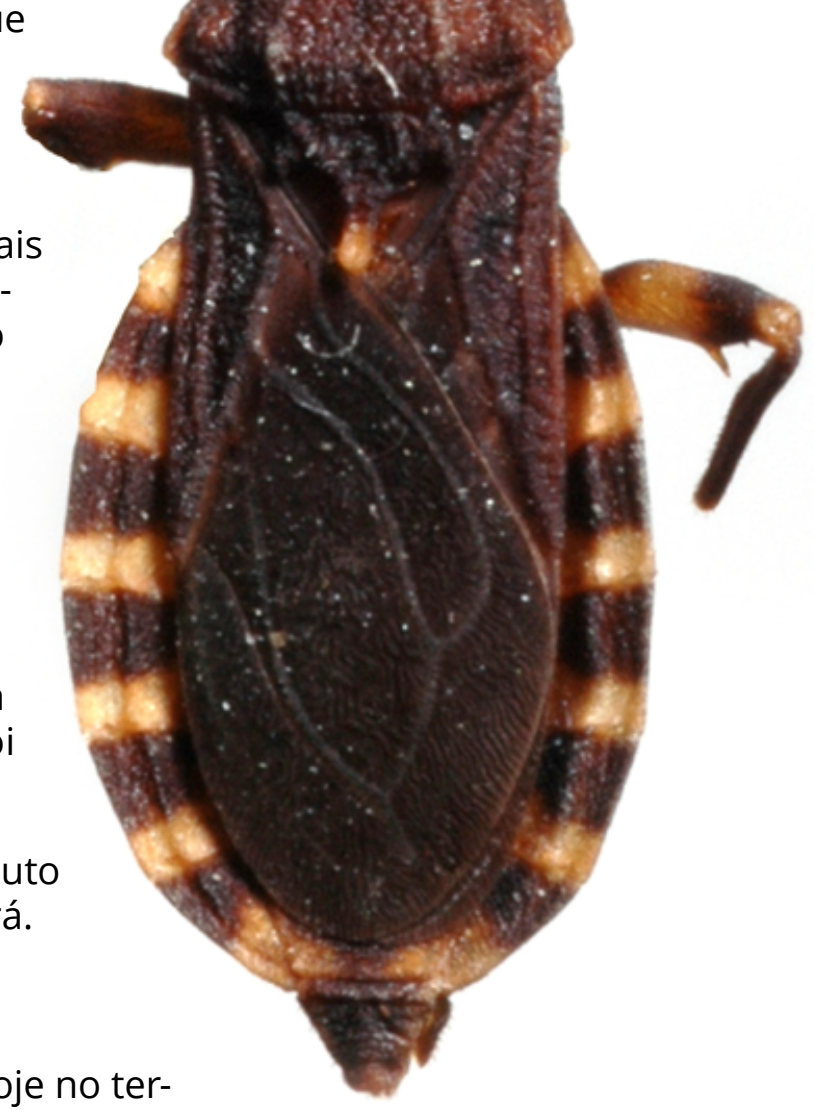




\section{Cavernicola lenti Barrett \& Arias, 1985}

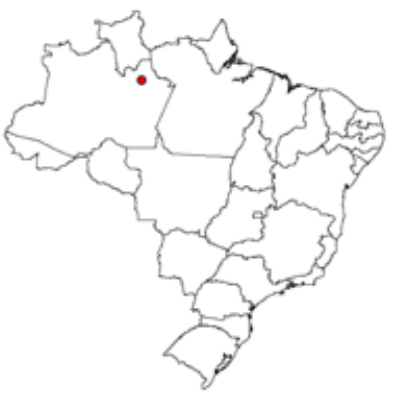

Etimologia: o nome genérico Cavernicola vem do latim "cavern". Cavernícola significa aquele que vive em cavernas ou apresenta hábitos cavernícolas. O epíteto específico lenti é uma homenagem a Herman Lent (1911-2004), notável entomólogo brasileiro e maior autoridade mundial em taxonomia de triatomíneos.

Características gerais: Comprimento total dos machos de 9,5 a 10 mm, das fêmeas de 11 a 12 mm. Coloração geral negra com exceção de áreas amareladas no quinto segmento conexival, metade posterior do abdômen e partes da membrana e cório dos hemiélitros. Tegumento liso e muito piloso com discretos grânulos e áreas com rugosidades. Cabeça globular em vista dorsal, ligeiramente mais curta que o pronoto. Região inter-ocular com mais que o dobro da largura de um olho em vista dorsal (proporção = 2,3-2,5:1). Região anteocular mais curta que a pós-ocular (proporção =1:1,1$1,2)$. Olhos pequenos mas muito projetados lateralmente. Ocelos pequenos, situados logo após o sulco pós-ocular. Tubérculos anteníferos sem dentículos, inseridos próximos ao bordo anterior dos olhos. Primeiro artículo antenal ultrapassando o nível do ápice do clípeo. Proporções entre os artículos antenais $=1: 2,3: 3: 3,1-3,3$. Rostro com primeiro segmento atingindo o nível do ápice do tubérculo antenífero, terceiro segmento mais curto que o primeiro. Proporções entre os segmentos do rostro $=1: 2,5: 0,7$. Pronoto com declive abrupto anteriormente, lobo anterior quase obscurecendo o colar em vista dorsal. Escutelo com processo apical mais longo que o comprimento do corpo do escutelo. Pernas predominantemente negras, raramente com trocânteres e base dos fêmures mais clara que a porção distal dos fêmures em espécimes secos. Fossetas esponjosas ausentes em ambos os sexos. Para descrição completa veja Barret \& Arias (1985) e Oliveira et al. (2007).

Material tipo: depositado na Coleção Herman Lent do Instituto Oswaldo Cruz, Rio de Janeiro, no Instituto de Pesquisas da Amazônia, Manaus, no National Museum of Natural History, Smithsonian Institution, Washington D.C. EUA e no American Museum of Natural History, Nova lorque, EUA.

Habitat: ocos de árvores em associação com Eratyrus mucronatus (Triatominae), Rhipidomys sp. (Rodentia) e Phyllostomus elongatus (Microchiroptera) (Barrett \& Arias 1985).

Curiosidades: quando um dos membros da colônia é tocado, os demais espécimes se movem freneticamente numa reação em cadeia. Em laboratório podem se alimentar de camundongos, pombos, galinhas e no ser humano.

Distribuição: Amazonas. 


\section{Cavernicola pilosa} Barber, 1937

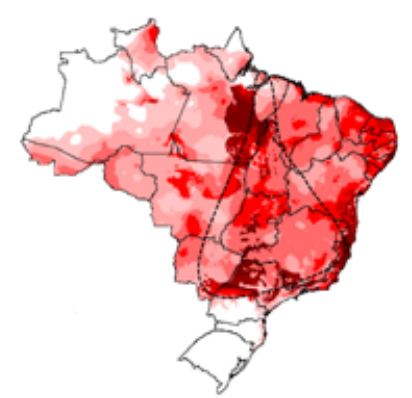

Etimologia: o epíteto especir
vem do latim "pilos" que signif
ludo uma referência ao asp
piloso do inseto.
Características gerais:
Comprimento total dos
machos de 11 a 11,5 mm,
das fêmeas de 12 a 13,8

$\mathrm{mm}$. Coloração geral negra com áreas amareladas principalmente nos hemiélitros. Corpo piloso. Tegumento liso no pronoto e abdômen, com granulação discreta na cabeça e rugosidade na meso e metapleura. Cabeça fusiforme em vista dorsal, em vista lateral muito convexa dorsalmente. Região anteocular igual ou levemente mais longa que à região pós-ocular (proporção $=1: 0,96$ ). Base do tubérculo antenífero alcançando o bordo anterior do olho. Olhos inseridos na linha mediana da cabeça. Ocelos muito pequenos, quase imperceptíveis, inseridos ao nível do tegumento, situados sobre ou logo após o sulco pós-ocular. Rostro com primeiro segmento muito curto, não atingindo o nível do ápice do tubérculo antenífero; segundo segmento muito longo, atingindo o nível do bordo posterior da cabeça, terceiro segmento curto. Proporções entre os segmentos do rostro =1:4,2:1,2. Pronoto mais largo que longo (proporção =1: 0,73 ) e mais curto que a cabeça (proporção $=1: 0,93$ ), estriado entre os lobos anteriores e posteriores. Lobo anterior castanho pálido. Escutelo triangular, processo apical muito pequeno. Cório castanho enfumaçado, com duas manchas amareladas com bordas indistintas. Membrana glabra, castanha enfumaçada, com nervuras amareladas distintas. Abdômen castanho escuro. Pernas castanho escuro, exceto coxas e trocânteres e bases dos fêmures que são amarelados. Fêmures dilatados, fusiformes, sem dentículos. Fossetas esponjosas ausentes em ambos os sexos. Para descrição completa veja Lent \& Wygodzinsky (1979) e Oliveira et al. (2007).

Material tipo: depositado no National Museum of Natural History, Smithsonian Institution, Washington, D.C., EUA.

Habitat: ocos de árvores e cavernas habitadas por morcegos, há registros de raros encontros em domicílios (Gomes \& Pereira 1977, Barbosa et al. 2005).

Distribuição: Bahia, Espírito Santo, Goiás, Mato Grosso, Mato Grosso do Sul, Minas Gerais, Pará, Paraná e Tocantins.

Distribuição fora do Brasil: Colômbia, Equador, Guiana Francesa, Panamá, Peru e Venezuela. 


\section{Eratyrus mucronatus Stål, 1859}

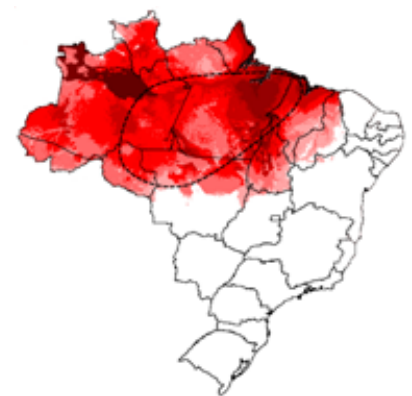

Etimologia: o nome genérico Eratyrus vem do grego "erat" que significa encantador, adorável. O epíteto específico mucronatus vem do latim "mucro" que significa ponta afiada, uma referência aos espinhos presentes no pronoto.

Sinônimos: Conorhinus mucronatus Walker, 1873

Características gerais: Comprimento total dos machos de 23 a 27 mm, das fêmeas de 25,5 a $29 \mathrm{~mm}$. Coloração geral marrom escuro ou negra, com as laterais do pescoço amareladas; cório com manchas avermelhadas subapicalmente, anteriormente não atingindo o nível da veia transversa $\mathrm{m}$-cu. Tegumento liso com pelos curtos. Cabeça duas ou uma e meia vezes mais longa que larga na região dos olhos (proporção=1:0,4) e distintamente mais longa que o pronoto (proporções=1:0,75-0,80). Região anteocular cerca de três vezes mais longa que pós-ocular (proporção=1:0,30-0,35). Genas cônicas apicalmente, jugas rombas apicalmente. Olhos em vista lateral atingindo o nível da superfície superior e inferior da cabeça. Tubérculos anteníferos situados no centro da região anteocular. Primeiro artículo antenal atingindo ou ultrapassando levemente o ápice do clípeo; proporções entre os artículos antenais $=1: 4,6-5,0: 3,6-3,9: 2,9-3,2$. Rostro com cerdas muito curtas e esparsas com exceção do terceiro segmento com pelos mais longos. Proporções entre os segmentos rostrais $=1: 1,05-1,25: 0,25-0,35$. Pescoço negro, amarelado nos lados. Pronoto com lobo anterior com 1+ 1 espinhos discais fortes; ângulos humerais do pronoto nitidamente espinhosos. Tubérculos discais na forma de espinhos aguçados. Húmeros com distintas projeções espiniformes suberectas de comprimento variado, mas invariavelmente mais curtas que os espinhos do lobo anterior. Projeções ântero-laterais do pronoto proeminentes, alongadas, subcônicas mas não espiniformes. Escutelo com processo apical espinhoso, inclinação do espinho escutelar extremamente variável, formando um ângulo entre o espinho e o hemiélitro que varia de $30 \mathrm{a}$ 60 graus. Para descrição completa veja Lent \& Wygodzinsky (1979).

Material tipo: depositado no Zoologisches Museum, Berlin, Alemanha.

Habitat: cavernas e árvores ocas habitadas por morcegos e roedores, palmeiras, ninhos de mamíferos. Já foi encontrada associada com Cavernicola pilosa e Triatoma maculata e também em domicílios da Bolívia, Colômbia e Venezuela (Noireau et al.1995, Carcavallo et al. 1998, Molina et al. 2000, Vivas et al. 2001).

Distribuição: Amazonas, Maranhão, Mato Grosso, Pará, Rondônia e Tocantins.

Distribuição fora do Brasil: Bolívia, Colômbia, Equador, Guatemala, Guiana, Guiana Francesa, Panamá, Peru, Suriname, Trinidad e Venezuela. 


\section{Microtriatoma borbai Lent \& Wygodzinsky, 1979}

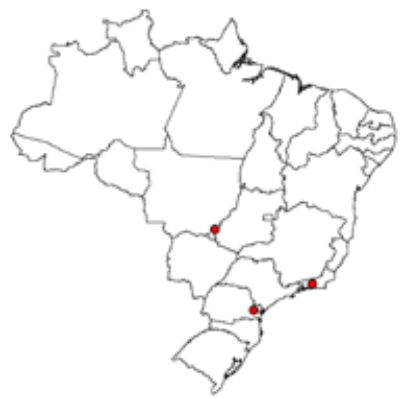

Etimologia: o nome genérico Microtriatoma vem do grego "micro" que significa pequeno, uma referência ao pequeno tamanho dos insetos desse gênero. O epíteto específico borbai é uma homenagem a Antonio Mário Borba, professor aposentado do Departamento de Patológica Básica, Universidade Federal do Paraná, que encontrou a espécie em bromélias.

Características gerais: Comprimento total dos machos de 7 a $8 \mathrm{~mm}$, das fêmeas 7,5 mm. Coloração geral marrom escuro a negra. Cabeça robusta em vista lateral, em vista dorsal mais longa que larga (proporção $=1: 0,8)$ e mais curta que o pronoto (proporções 1:1,1-1,2). Região anteocular variando de ligeiramente mais longa a tão longa quanto a região pós-ocular (1:0,9-1,0). Região pós-ocular semicircular, muito curta. Proporção entre a largura de um olho e a região interocular $=1: 2,5$. Proporções entre os segmentos antenais $=$ $1: 1,5-1,9: 1,3-1,4: 1,5-1,9$. Proporções entre os artículos rostrais $=1: 1,8-2,0: 1,0$. Pronoto com os lobos anterior e posterior quase contínuos, não formando um ângulo muito marcado; ângulos ântero laterais pontudos. Ápice dos hemiélitros dos machos alcançando o bordo posterior do VII tergito, das fêmeas apenas alcançando o bordo basal do VII tergito. Para descrição completa veja Lent \& Wygodzinsky (1979).

Material tipo: depositado na Coleção Herman Lent do Instituto Oswaldo Cruz, Rio de Janeiro e no American Museum of Natural History, Nova lorque, EUA.

Habitat: em bromélias próximas a refúgios de roedores e marsupiais (Lent \& Wygodzinsky 1979). Na copa da palmeira Mauritia flexuosa (Gurgel-Gonçalves, dados não publicados)

Curiosidades: no laboratório recusaram alimentação em pombos, galinhas, ratos, ou humanos (Lent \& Wygodzinsky 1979).

Distribuição: Goiás, Mato Grosso, Paraná e Rio de Janeiro.

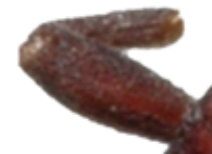

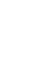

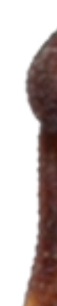

\section{6}

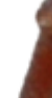

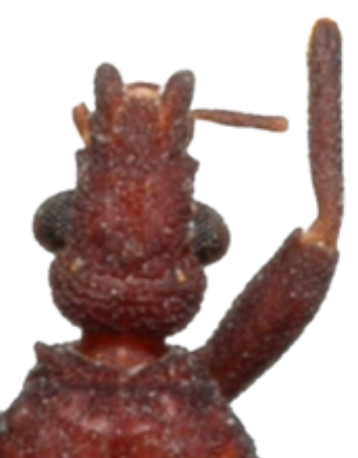




\section{Microtriatoma trinidadensis (Lent, 1951)}

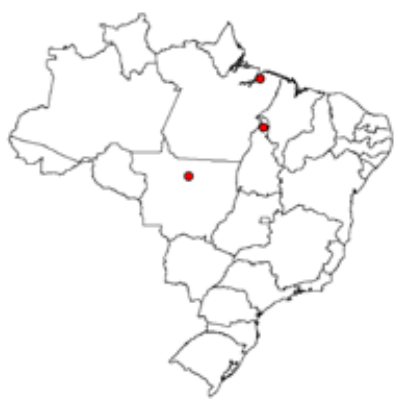

Etimologia: o epíteto específico trinidadensis é uma referência a ilha de Trinidad, onde esses insetos foram encontrados pela primeira vez.

Sinônimos: Bolbodera trinidadensis Lent, 1951; Microtriatoma mansosotoi Prosen \& Martínez, 1952.

Características gerais: Comprimento total dos machos de 7,5 a 8,0 mm, das fêmeas 7,5 mm. Coloração geral marrom-escuro ou negra. Cabeça estreita em vista lateral. Em vista dorsal a cabeça é cerca de uma, a uma vez e meia mais longa que larga $(1: 0,6-0,7)$, e tão longa ou ligeiramente mais curta que o pronoto $(1: 1,0-1,2)$. Região anteocular variando de ligeiramente mais longa a ligeiramente mais curta que a pós- ocular (1:0,8-1,1). Região pós-ocular variando de sub-retangular a semicircular, invariavelmente mais larga que longa. Proporção entre largura de um olho e região interocular = 1:2,2. Proporções entre artículos antenais $=1: 1,3-2,1: 1,3-2,1: 1,7-$ 2,3 . Proporções entre os segmentos do rostro $=1: 1,5-1,7: 0,7-0,8$. Pronoto com lobos anterior e posterior quase contínuos, não formando um ângulo evidente. Ângulos ântero-laterais do pronoto de rombos a distintamente pontudos. Escutelo com depressão no centro. Pernas escuras com coxas e trocânteres amarelados. Fêmur dianteiro mais largo no terço anterior, quase quatro vezes mais longo que largo. Hemiélitro com cório distintamente piloso; de cor escura com manchas claras na membrana. Áreas brancas maiores na metade apical do clavo, ao nível do ápice do processo escutelar, em áreas adjacentes a membrana, e em uma faixa estreita da membrana adjacente a porção apical do cório. Ápice do hemiélitro alcançando o bordo posterior do VII tergito em ambos os sexos. Conexivo dorsal e ventral com estreita faixa amarelada antes de cada sutura intersegmental, próxima margem externa mais larga dos segmentos. Espiráculos amarelados. Para descrição completa veja Lent \& Wygodzinsky (1979).

Material tipo: de M. trinidadensis depositado na Coleção Herman Lent do Instituto Oswaldo Cruz, Rio de Janeiro. De M. mansosotoi depositado na Misión de Estudios de Patologia Regional (MEPRA), Buenos Aires, Argentina.

Habitat: palmeiras e cavidades de árvores, escondido entre as folhas, dentro de ninhos de gambás (Didelphis marsupialis). Na Bolívia foi encontrada uma colônia peridomiciliar em um galinheiro construído com folhas da palmeira Attalea phalerata (De la Riva et al. 2001).

Curiosidades: Em laboratório recusaram alimentação em galinhas, ratos e humanos, entretanto, uma ninfa realizou coprofagia nas fezes de Rhodnius (De la Riva et al. 2001).

Distribuição: Mato Grosso, Pará e Tocantins.

Distribuição fora do Brasil: Bolívia, Colômbia, Guiana Francesa, Peru, Trinidad e Venezuela. 


\section{Panstrongylus diasi Pinto \& Lent, 1946}

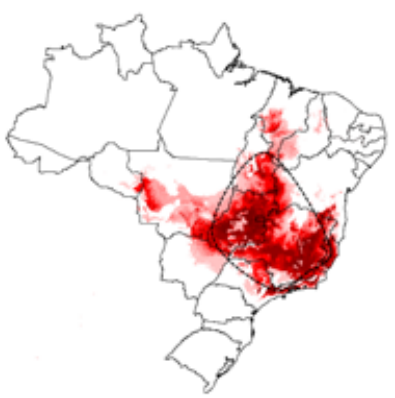

Etimologia: o nome genérico Panstrongylus vem do grego "pan" que significa todo e "strongylus" que significa redondo, roliço, corpulento, uma referência ao corpo robusto e arredondado do inseto. O epíteto específico diasi é uma homenagem a Ezequiel Dias (1880-1927), um dos pioneiros no estudo dos vetores da doença de Chagas no Brasil.

Características gerais: Comprimento total dos machos $26 \mathrm{~mm}$, das fêmeas $27 \mathrm{~mm}$. Coloração geral marrom amarelado com áreas marrom-escuro no pronoto, pleura, escutelo, cório e conexivo. Superfície do corpo aparentemente glabra. Cabeça muito mais curta que o pronoto $(1: 1,3)$. Região anteocular com menos que o dobro do comprimento da pós-ocular (1:0.60-0.65). Genas não atingindo o nível do ápice do clípeo. Jugas rombas no ápice. Cabeça não nitidamente elevada entre os olhos. Olhos em vista lateral alcançando o nível da superfície ventral de cabeça, mas não alcançando a superfície dorsal. Proporção entre a largura de um olho e região interocu$\operatorname{lar}=1: 2,3-2,8$. Tubérculos anteníferos com processo apicolateral pequeno, mas distinto. Primeiro artículo antenal se estendendo além do nível do ápice do clípeo. Rostro com primeiro segmento quase alcançando o nível da margem anterior de olhos, o segundo alcançando o nível da base do pescoço. Primeiro e segundo segmentos rostrais quase completamente glabros ou com cerdas curtas e escassas, terceiro segmento com numerosa pilosidade. Proporções entre os segmentos rostrais $=1: 1,45: 0,60-0,65$. Pronoto marrom avermelhado com diversas áreas escuras. Lobo anterior do pronoto sem tubérculos discais e laterais. Margens laterais do lobo anterior e posterior quase contínuas, não formando um ângulo distinto. Ângulos humerais arredondados. Ângulos ântero-laterais curtos e rombos. Processo apical do escutelo aproximadamente do comprimento do corpo principal do escutelo. Hemiélitro se estendendo até o ápice do abdômen; de cor marrom amarelado, com grande área central do cório marrom escuro. Membrana enfumaçada. Pernas esguias, fêmures anteriores com um par de dentículos subapicais robustos seguido ou não de um dentículo adicional pequeno; fêmures medianos com dentículos semelhantes, ou sem dentículos. Fossetas esponjosas presentes nas tíbias anteriores e medianas em ambos os sexos. Conexivo com mancha sub-retangular preta adjacente a sutura intersegmental. Para descrição completa veja Lent \& Wygodzinsky (1979).

Material tipo: depositado na Coleção Herman Lent do Instituto Oswaldo Cruz, Rio de Janeiro.

Habitat: habitats silvestres desconhecidos, encontrado em domicílios e peridomicílios (Carcavallo et al. 1998).

Distribuição: Bahia, Distrito Federal, Espírito Santo, Goiás, Maranhão, Mato Grosso do Sul, Minas Gerais, São Paulo e Tocantins.

Distribuição fora do Brasil: Bolívia. 


\section{Panstrongylus geniculatus (Latreille, 1811)}

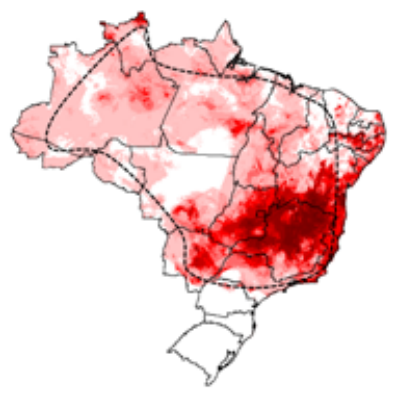

Etimologia: o epíteto específico geniculatus vem do latim "geniculatus", "geniculata", "geniculatum" e significa intrincado, cheio de nós.

Sinônimos: Reduvius geniculatus Latreille, 1811; Conohrinus lutulentus Erichson, 1848; Lamus geniculatus Stål, 1859; C. corticalis Walker, 1873; C. geniculatus Walker, 1873; L. corticalis Lethierry \& Severin, 1896; Triatoma geniculata Chagas, 1912; T. tenuis Neiva, 1914; T. fluminensis Neiva \& Pinto, 1922; Mestor geniculatus Brindley, 1931; Panstrongylus parageniculatus Ortiz, 1971.

Características gerais: Comprimento total dos machos de 22 a 28 $\mathrm{mm}$, das fêmeas de 22,5 a 29,5 mm. Coloração geral marrom claro ou marrom alaranjado, com elementos escuros em várias partes de corpo. Cabeça mais longa que larga na altura dos olhos (proporção $=1: 0,70-0,75$ ) e mais curta que o pronoto (1:1,15-1,30). Região anteocular com cerca de duas vezes o comprimento da pós- ocular (1:0,45-0,55). Genas atingindo o nível do ápice do clípeo. Juga em forma de gancho incipiente. Proporção entre largura de um olho e região interocular= 1:1,45-1,9. Tubérculo antenífero, com processo apicolateral pronunciado. Antena variando de marrom avermelhado ao negro. Primeiro artículo antenal ultrapassando ligeiramente o nível do ápice do clípeo; proporções entre os artículos antenais $=1: 3,0-3,7: 2,35-2,80: 2,5-2,7$. Rostro marrom escuro com o primeiro segmento se aproximando ou ultrapassando ligeiramente o nível da margem anterior dos olhos; segundo segmento atingindo o nível do meio do pescoço. Proporção entre segmentos rostrais $=1: 1,0-1,3: 0,45-0,55$. Pronoto marrom alaranjado. Lobo anterior do pronoto com marca central negra em forma de trevo de quatro folhas,

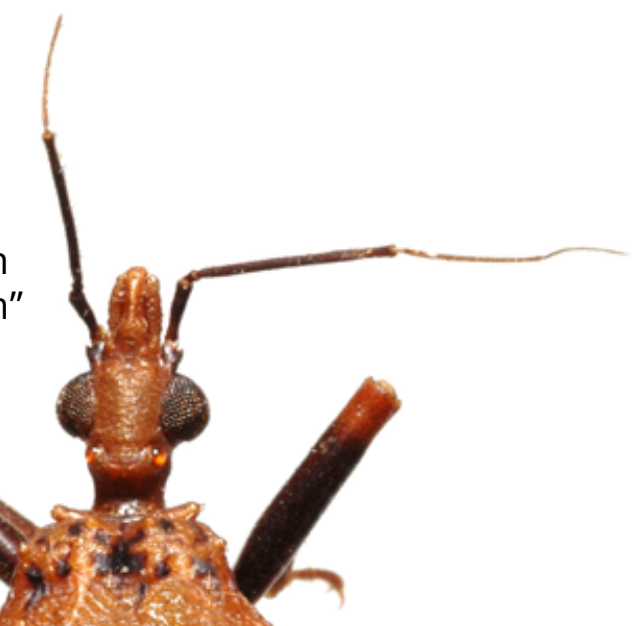
e 1+1 marcas laterais negras. Lobo posterior com faixa preta ao longo da margem posterior excluindo a região humeral. Tubérculos discais e laterais de pequenos a obsoletos. Ângulos ântero-laterais arredondados. Escutelo e seu processo preto. Hemiélitro de cor global marrom amarelado, com veias da membrana, escuras. Fêmures dianteiros com 2-6 dentículos subapicais em duas filas. Fossetas esponjosas presentes nas tíbias anteriores e medianas em ambos os sexos. Coxas e trocânteres amarelados ou alaranjados. Fêmures e tíbias marrom escuro ou preto, com anel apical laranja. Abdômen marrom alaranjado com manchas negras. Conexivo amarelado com mancha negra no terço anterior de cada segmento. Para descrição completa veja Lent \& Wygodzinsky (1979).

Material tipo: de P. geniculatus, C. lutulentus e P. parageniculatus desconhecidos, de C. corticalis depositado no British Museum (Natural History), Londres, Inglaterra, de T. tenuis e T. fluminensis depositados na Coleção Herman Lent do Instituto Oswaldo Cruz, Rio de Janeiro. 
Habitat: tocas de tatus e pacas, em cavernas, sob cascas de árvores, próximos a ninhos de aves, em várias espécies de palmeiras e associados a porcos nos peridomicílios (Carcavallo et al. 1998, Valente 1999).

Curiosidades: Espécie com grande variabilidade morfológica. É considerada silvestre, porém, os adultos são atraídos pela luz e encontrados com frequência no interior de domicílios humanos.

Distribuição: Acre, Amapá, Amazonas, Bahia, Ceará, Distrito Federal, Espírito Santo, Goiás, Maranhão, Mato Grosso, Mato Grosso do Sul, Minas Gerais, Pará, Paraná, Piauí, Rio de Janeiro, Rondônia, Roraima, São Paulo e Tocantins.

Distribuição fora do Brasil: Argentina, Bolívia, Colômbia, Costa Rica, Equador, Guatemala, Guiana, Guiana Francesa, México, Nicarágua, Panamá, Paraguai, Peru, Suriname, Uruguai, Trinidad e Venezuela. 


\section{Panstrongylus guentheri Berg, 1879}

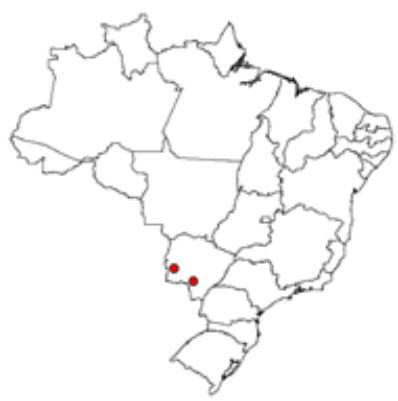

Etimologia: o epíteto específico guentheri é uma homenagem a Albrecht K.L.G. Günther (1830-1914), zoólogo alemão.

Características gerais: Comprimento total dos machos de 22 a $25 \mathrm{~mm}$, das fêmeas de 24 a $27 \mathrm{~mm}$. Coloração geral marrom alaranjado, com elementos marrom escuro em áreas do pronoto, pleura, escutelo, cório e conexivo. Superfície de corpo aparentemente glabra. Cabeça uniformemente marrom alaranjada, uma vez e meia mais longa que a largura na altura dos olhos (1:0,6-0,7), e muito mais curta que o pronoto $(1: 1,4-1,5)$. Região anteocular com menos de duas vezes o comprimento da pós-ocular (1:0,550,65). Genas não atingindo o nível do ápice do clípeo. Cabeça fortemente elevada dorsalmente entre os olhos. Olhos em vista lateral comparativamente pequenos, afastados da superfície dorsal da cabeça. Proporção entre a largura dos olhos e a região interocular =1:2,10-2,5. Ocelos circundados por anelação escura. Tubérculo antenífero com pequeno processo apicolateral. Primeiro artículo antenal muito longo ultrapassando o nível do ápice do clípeo. Proporções entre os artículos antenais = 1:2,8-3,2:2,2-2,5:?. Rostro com primeiro segmento atingindo a margem anterior dos olhos, segundo segmento estendendo-se até o nível da base do pescoço. Proporções entre os segmentos rostrais $=1: 1,55-1,70: 0,55-0,70$. Pronoto marrom avermelhado a totalmente marrom escuro. Lobo anterior visivelmente convexo; tubérculos discais obsoletos, tubérculos laterais ausentes. Pronoto com distinto ângulo formado entre os lobos anterior e posterior. Ângulos ântero-laterais proeminentes. Escutelo marrom escuro, com processo apical tão longo quanto o corpo principal do escutelo. Hemiélitro alcançando o ápice do sétimo urotergito. Cório marrom escuro exceto por uma região subtriangular na base. Fêmures anteriores e medianos com duas colunas de três a cinco dentículos cada. Pequenos dentículos adicionais irregularmente posicionados próximos à base do fêmur. Fosseta esponjosa presente nos fêmures anteriores e medianos dos machos, nas fêmeas muito pequenas. Pernas avermelhadas, ou alaranjadas. Conexivo marrom alaranjado, com marca escura de formato irregular. Para descrição completa veja Lent \& Wygodzinsky (1979).

Material tipo: de P. guentheri depositado no Museo de La Plata, Argentina; de $P$. larroussei depositado na Coleção Herman Lent do Instituto Oswaldo Cruz, Rio de Janeiro; de $P$. seai desconhecido.

Habitat: abrigos de roedores e outros mamíferos, ninhos de aves, sob cascas de árvores e pilhas de lenha. Adultos são ocasionalmente encontrados em domicílios (Carcavallo et al. 1998, Almeida et al. 2008).

Distribuição: Mato Grosso do Sul.

Distribuição fora do Brasil: Argentina, Bolívia, Paraguai e Uruguai. 


\section{Panstrongylus lenti Galvão \& Palma, 1968}

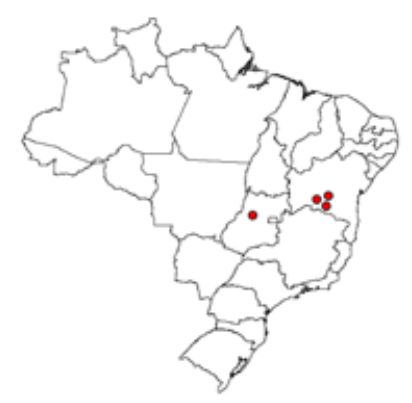

Etimologia: o epíteto específico lenti é uma homenagem a Herman Lent (1911-2004), notável entomólogo brasileiro e maior autoridade mundial em taxonomia de triatomíneos.

Características gerais: Comprimento dos machos $18 \mathrm{~mm}$, das fêmeas $19 \mathrm{~mm}$. Coloração geral marrom claro levemente avermelhado, com manchas escuras no pronoto, hemiélitro, pleura e abdômen. Cabeça uma vez e meio mais longa que larga na altura dos olhos (1:0.65) e mais curta que o pronoto (1:1.2). Região anteocular com pouco menos que o dobro do comprimento da pós- ocular (1:0.55). Clípeo alargado posteriormente. Genas arredondadas apicalmente, atingindo o nível do ápice do clípeo. Olhos em vista lateral ultrapassando o nível inferior da cabeça, mas não alcançando o nível da superfície dorsal. Proporção entre a largura de um olho e a região interocular $=1: 2$. Tubérculo antenífero com pequeno, porém distinto, processo apicolateral. Primeiro artículo antenal marrom avermelhado não alcançando o ápice do clípeo. Primeiro segmento do rostro atingindo o nível da margem anterior dos olhos, segundo estendendo-se além do nível do meio do pescoço. Primeiro e segundo segmentos rostrais quase glabros, terceiro com pelos longos. Proporções entre os segmentos rostrais $=1: 1.1: 0,5$. Pronoto com tubérculos discais pequenos mas distintos, tubérculos laterais obsoletos. Lobo posterior do pronoto distintamente rugoso. Ângulos humerais arredondados. Ângulos ântero-laterais bem desenvolvidos, subcônicos. Escutelo com processo apical tão longo quanto o corpo do escutelo. Hemiélitro atingindo o ápice do abdômen. Cório e clavo cor de palha, exceto a célula adjacente ao calvo e ápice do cório que são marrons. Membrana marrom, enfumaçada. Pernas uniformemente marrom-amarelado claro. Fêmures com metade apical com três pares de pequenos dentículos. Fossetas esponjosas ausentes. Uroesternitos III e VI com nítidas manchas negras sublaterais. Placas conexivais dorsais III e IV com pequenas manchas escuras próximas ao bordo anterior. Para descrição completa veja Lent \& Wygodzinsky (1979) e Barata et al. (1997).

Material tipo: depositado na Coleção Herman Lent do Instituto Oswaldo Cruz, Rio de Janeiro e na Faculdade de Saúde Pública, Universidade de São Paulo.

Habitat: Em Goiás foi encontrada entre as roupas de um viajante (procedência incerta) e também dentro de um domicílio (Galvão \& Palma 1968, Lent \& Wygodzinky 1979, Barata et al. 1997).

Curiosidades: É a menor e mais rara espécie do gênero Panstrongylus.

Distribuição: Bahia, Goiás.

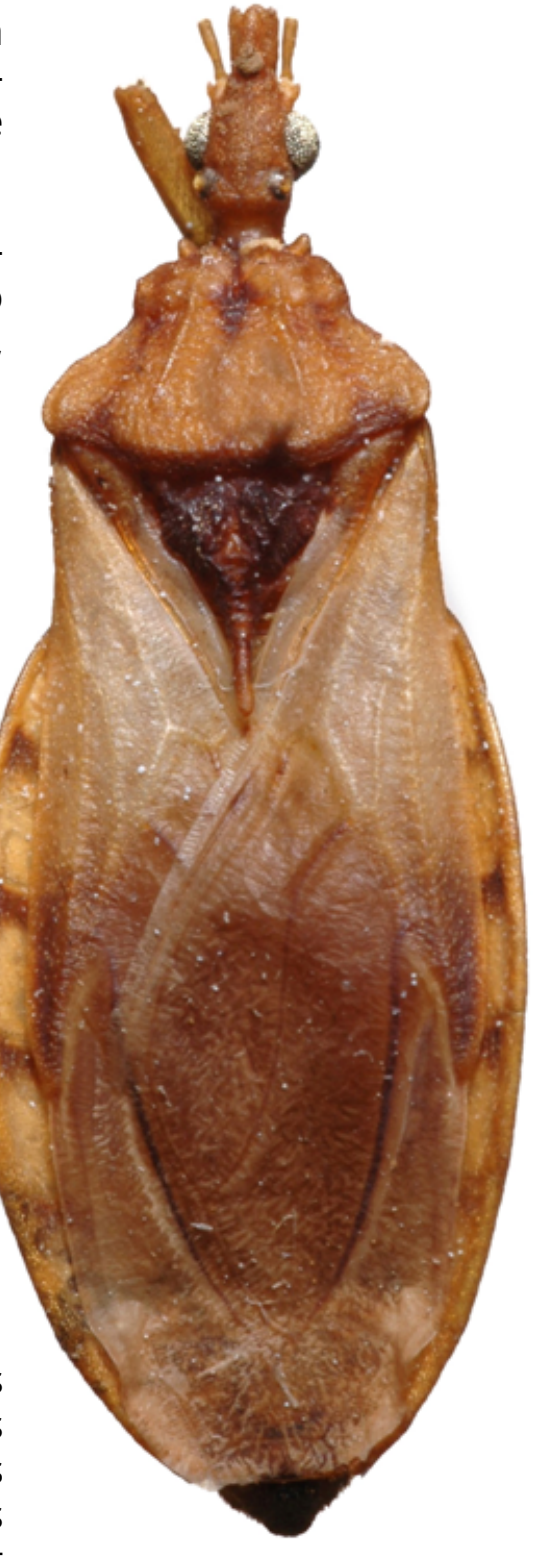




\section{Panstrongylus lignarius (Walker, 1873)}

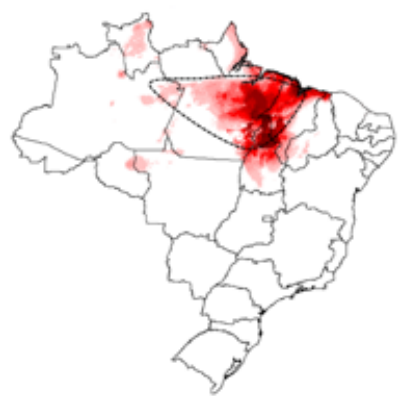

Etimologia: o epíteto específico lignarius vem do latim "lignum" que significa madeira, uma referência ao aspecto do inseto que apresenta coloração similar à madeira.

Sinônimos: Conorhinus lignarius WaIker, 1873; Eratyrus lignarius Lethierry \& Severin, 1896; Conorrhinus lignarius Champion, 1899; Lamus lignarius Distant, 1902; Triatoma lignarius Neiva, 1911; Mestor lignarius Usinger, 1939; Panstrongylus herreri Wygodzinsky, 1948.

Características gerais: Comprimento dos machos de 20,5 a 26 mm, das fêmeas de 23 a 31 $\mathrm{mm}$. Coloração geral marrom claro a amarelado dorsalmente; marrom escuro ou negro ventralmente. Manchas marrom escuro a negro presentes na cabeça, pescoço, pronoto, escutelo, hemiélitro e conexivo. Pernas negras com anelações ou manchas amareladas. Superfície do corpo com cerdas douradas muito pequenas. Cabeça marrom amarelado claro, incluindo parcialmente ou inteiramente as genas e tubérculos anteníferos. Dorsalmente há uma faixa escura longitudinal de forma irregular, estendendo-se do nível das jugas até próximo aos ocelos. Búcula e toda a superfície inferior da cabeça negra. Cabeça uma vez e meio mais longa que larga na altura dos olhos $(1: 0,60-0,75)$ e muito mais curta que o pronoto $(1: 1,1-1,4)$. Região anteocular três a quatro vezes mais longa que a pós-ocular. Genas atingindo, mas não ultrapassando, o nível do ápice de clípeo. Jugas com projeção pontuda curvada. Olhos grandes em ambos os sexos, em vista lateral ultrapassando o nível inferior, mas não o nível superior da cabeça. Proporção entre os artículos antenais $=1: 2,3-2,7: 2,1-2,7: 1,7-2,1$. Rostro negro. Primeiro segmento rostral atingindo o nível do ápice do tubérculo antenífero, segundo alcançando o nível do pescoço. Proporções entre os segmentos $=1: 1,3-1,4: 0,3-0,5$. Pronoto castanho claro ou amarelado, com manchas longitudinais escuras e ângulos humerais atipicamente projetados lateralmente. Lobo anterior do pronoto ligeiramente convexo, com 1+1 pequenos tubérculos discais, seguidos ou não por 1+1 tubérculos menores na base da carena submediana; tubérculos laterais bem desenvolvidos, porém, menores que os discais; $1+1$ tubérculos sublaterais adicionais presentes. Todos os tubérculos amarelos, polidos. Escutelo negro e amarelo, com processo apical muito curto. Hemiélitro marrom-claro a amarelado com diversas manchas negras ou marrons. Fêmures anteriores e medianos com 1+1 dentículos subapicais. Tíbias anteriores e medianas com fossetas esponjosas bem desenvolvidas em ambos os sexos. Coxas e metade basal dos trocânteres negros. Ápice dos trocânteres, base e ápice dos fêmures amarelos. Para descrição completa veja Lent \& Wygodzinsky (1979). 
Material tipo: depositado no British Museum (Natural History), Londres, Inglaterra. De P. herreri depositado no Instituto Miguel Lillo, Tucuman, Peru.

Habitat: palmeiras, árvores ocas, copas de árvores, ninhos de tucanos, bromélias, associada com marsupiais e roedores, galinheiros, e ocasionalmente em domicílios (Carcavallo et al. 1998, Gaunt \& Miles, 2000).

Curiosidades: os adultos apresentam uma excelente camuflagem, se confundindo com a folhagem das árvores nas quais eles são encontrados.

Distribuição: Amazonas, Maranhão, Pará e Tocantins.

Distribuição fora do Brasil: Equador, Peru, Guiana, Guiana Francesa, Suriname e Venezuela. 


\section{Panstrongylus lutzi (Neiva \& Pinto, 1923)}

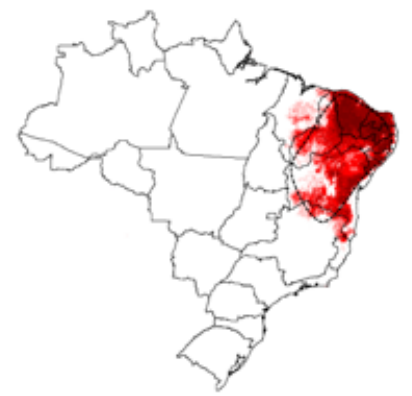

Etimologia: o epíteto específico lutzi é uma homenagem a Adolfo Lutz (1855-1940), parasitologista brasileiro.

Sinônimos: Triatoma lutzi Neiva \& Pinto, 1923; Panstrongylus sherlocki Jurberg, Carcavallo \& Lent, 2001.

Características gerais: Comprimento dos machos de 24,0 a 28,5 mm, das fêmeas de 28 a 29 mm. Coloração geral marrom amarelado, com marcas marrom escuro na cabeça, pronoto, pleura, escutelo, cório e conexivo. Superfície do corpo aparentemente glabra. Cabeça uniformemente marrom amarelado. Cabeça uma vez e meio mais longa que larga na altura dos olhos, processo apicolateral pequeno, porém distinto. Antena marrom avermelhado escuro. Primeiro artículo antenal ultrapassando o nível do ápice do clípeo; proporção entre os artículos antenais $=1: 2,9-3,3: 2,2-2,4: 1,95-2,0$. Rostro com primeiro segmento atingindo o nível do ápice do tubérculo antenífero, segundo alcançando o nível da base do pescoço. Proporções entre os segmentos rostrais =1:1,2-1,3:0,50-0,55. Cor do pronoto marrom amarelado com diversas áreas negras. Tubérculos discais grandes, arredondados, tubérculos laterais muito menores que os discais. Margens laterais do lobo anterior e posterior do pronoto formando um ângulo nítido. Ângulos humerais arredondados. Escutelo marrom escuro, com processo posterior em alguns espécimes marrom claro, processo apical tão longo quanto o corpo principal. Hemiélitro atingindo o ápice do abdômen em ambos os sexos. Cório marrom amarelado. Membrana quase tão negra quanto a porção escura do cório, enfumaçada. Fêmures anteriores e medianos com numerosos dentículos dis-

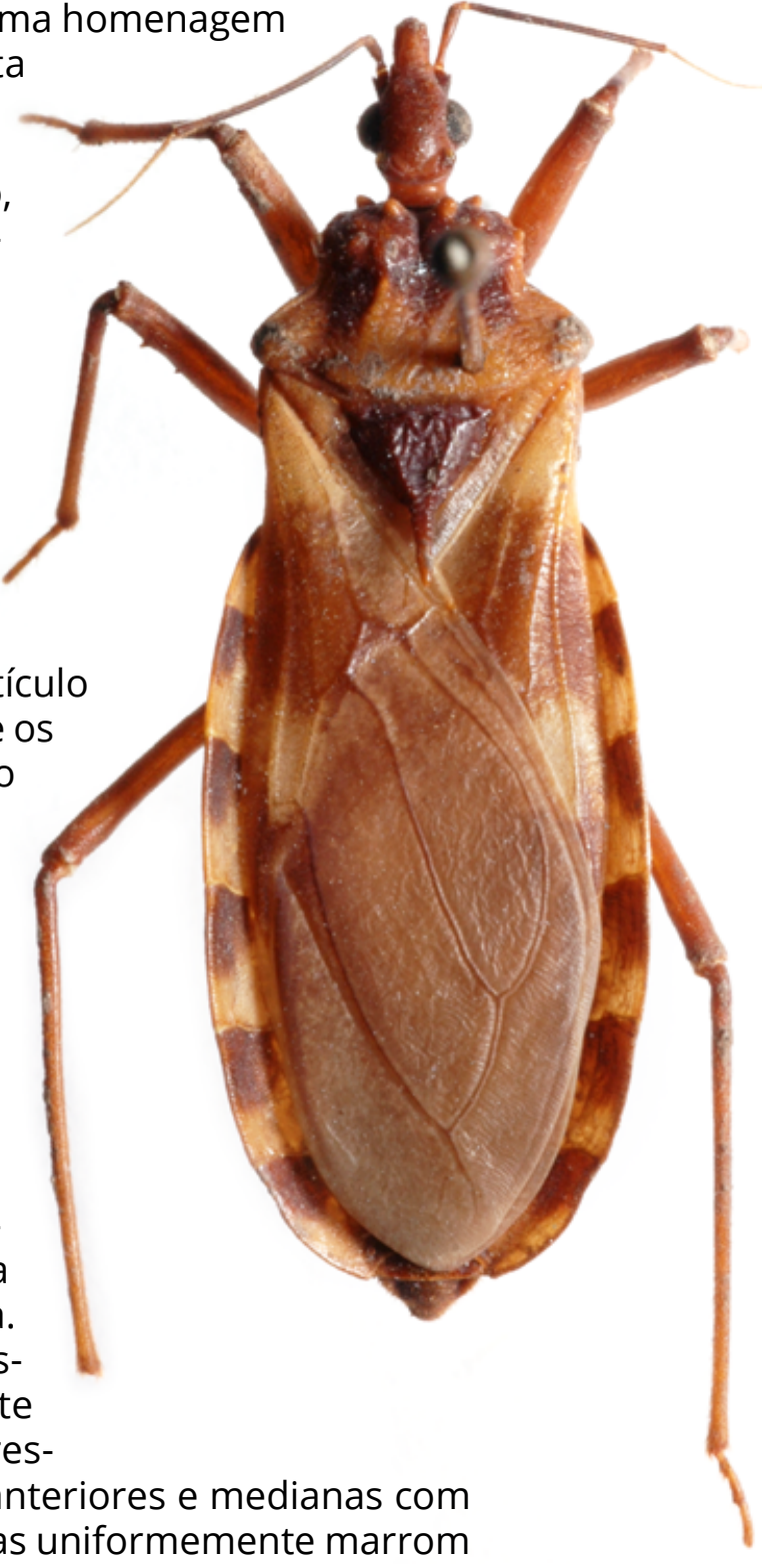
tribuídos em duas filas nos dois terços apicais, irregularmente distribuídos próximos a base do segmento, aumentando progressivamente de tamanho da base para o ápice do fêmur. Tíbias anteriores e medianas com fossetas esponjosas muito pequenas em ambos os sexos. Pernas uniformemente marrom avermelhado, um pouco mais escura no ápice. Conexivo marrom amarelado, terço ou metade anterior de cada segmento conexival com mancha marrom escura ou negra adjacente a sutura intersegmental. Para descrição completa veja Lent \& Wygodzinsky (1979).

Material tipo: de P. lutzi depositado na Coleção Herman Lent e de $P$. sherlocki depositado na Coleção Rodolfo Carcavallo, ambas do Instituto Oswaldo Cruz, Rio de Janeiro.

Habitat: Tocas de tatus (Euphractus sexcinctus e Dasypus novemcinctus) e rochas habitadas por mocós (Kerodon rupestris). Adultos são frequentemente encontrados no peridomicílio e dentro de casas, geralmente apresentam elevado índice de infecção por T. cruzi (Carcavallo et al. 1998).

Distribuição: Alagoas, Bahia, Ceará, Minas Gerais, Paraíba, Pernambuco, Piauí, Rio Grande do Norte e Sergipe. 


\section{Panstrongylus megistus (Burmeister, 1835)}

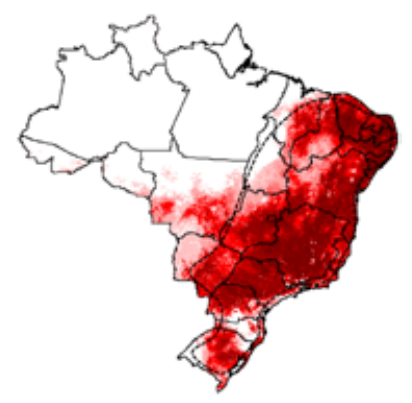

Etimologia: o epíteto específico megistus vem do grego "megisto" que significa maior.

Sinônimos: Lamus megistus Stål, 1859; Conorhinus gigas Burmeister, 1861; Triatoma africana Neiva, 1911; T. megista Neiva, 1911; T. megista var. wernickei Del Ponte, 1930; Panstrongylus africanus Pinto, 1931; P. megistus leucofasciatus Lucena, 1959;T. megistus Neiva, 1911; Mestor megistus Usinger, 1944; C. porrigens Walker, 1873; T. wernickei Del Ponte, 1923; T. megista var. wernickei Del Ponte, 1930

Características gerais: Comprimento dos machos de 26 a 34 mm, das fêmeas de 29 a 38 mm. Coloração geral negra com manchas vermelhas ou alaranjadas no pescoço, pronoto, escutelo, cório e conexivo. Superfície do corpo com cerdas curtas e pouco visíveis. Cabeça negra, cerca de uma vez e meio mais longa que larga na altura dos olhos $(1: 0,75-0,85)$ e muito mais curta que 0 pronoto $(1: 1,3-1,5)$. Região anteocular duas a três vezes mais longa que a pós-ocular (1:0,30-0,45). Clípeo estreito. Genas não se estendendo além do nível do ápice do clípeo. Jugas pontuda. Cabeça muito elevada na metade posterior. Olhos grandes, em vista lateral ultrapassando consideravelmente a superfície inferior da cabeça mas distante da superfície superior. Olhos dos

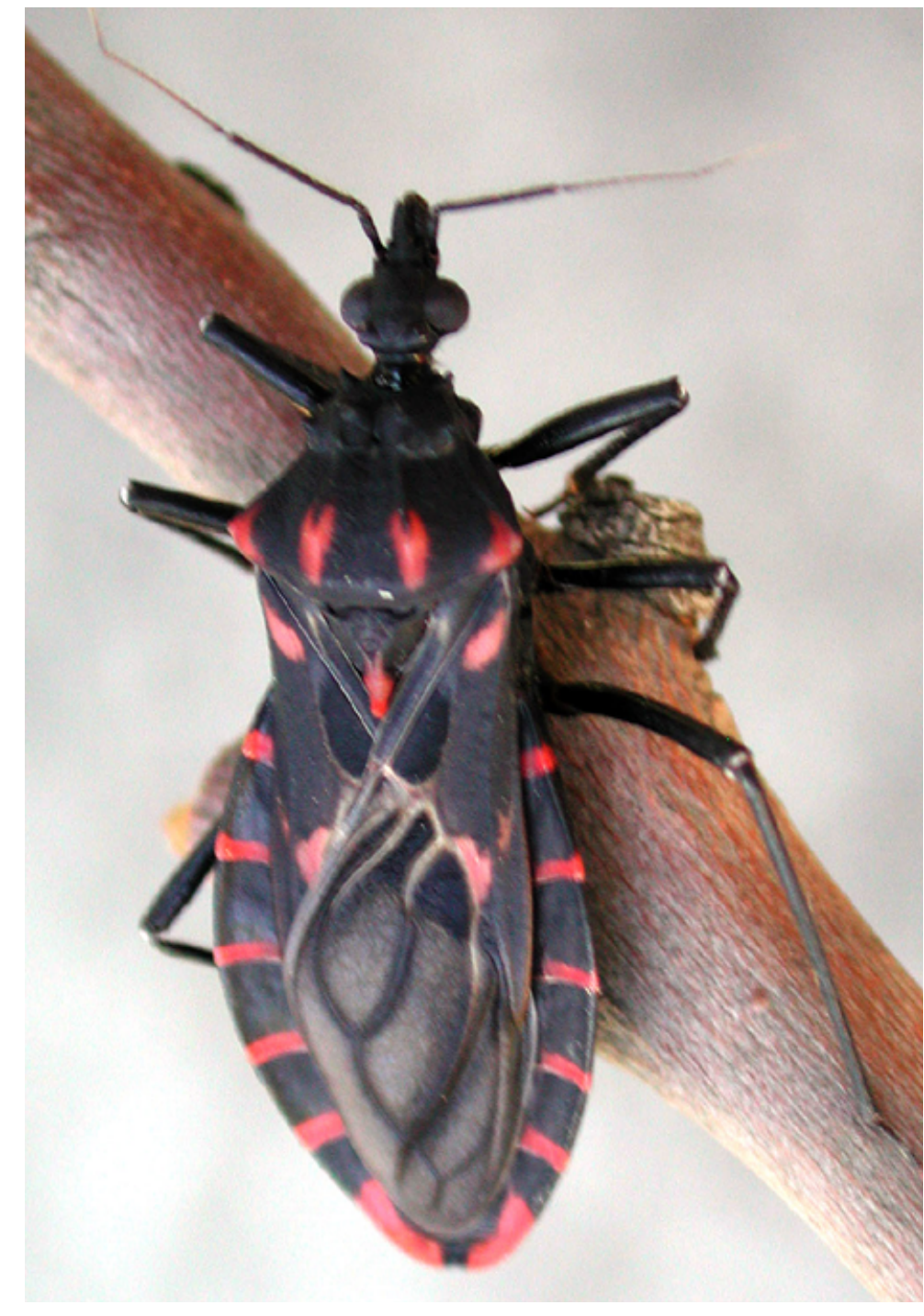
machos maiores que os das fêmeas. Proporção entre largura de um olho e região interocular =1:1,25-1,35 nos machos e 1:1,55-1,80 nas fêmeas. Tubérculos anteníferos sem processo apicolateral. Primeiro artículo antenal ultrapassando nitidamente o ápice do clípeo. Proporções entre os artículos antenais = 1:2,8-3,3:2,2-2,5:1,4-1,8. Primeiro segmento rostral atingindo o nível do ápice tubérculo antenífero ou, raramente, a margem anterior dos olhos; segundo segmento se estendendo até o nível do meio do pescoço. Proporção entre os segmentos rostrais $=1: 1,10-1,25: 0,40-0,55$. Pronoto com lobo anterior totalmente negro, raramente com 1+1 pequenas manchas avermelhadas entre os tubérculos dorsais e o colar, ou com tubérculos avermelhados; lobo posterior negro com 2+2 grandes manchas vermelhas na metade ou terço posterior, 1+1 manchas submedianas como continuação da carena submediana e 1+1 manchas laterais ocupando o húmero e áreas adjacentes. Tubérculos discais na maioria dos espécimes grandes, subcônicos; tubérculos laterais bem desenvolvidos, similares aos tubérculos discais. Ângulos ântero-laterais cônicos e alongados. Escutelo avermelhado, processo escutelar curto, com cerca de um terço a metade do comprimento do corpo do escutelo. Cório e membrana negros; cório com manchas 
vermelhas na base e subapicalmente. Base do clavo mais clara. Pernas negras, fêmures anteriores e medianos com par de pequenos dentículos subapicais. Fossetas esponjosas presentes nas tíbias anteriores e medianas dos machos, ausentes nas fêmeas. Abdômen ventral negro. Conexivo negro, com manchas vermelhas transversais localizadas no quarto posterior de cada segmento dorsal. Para descrição completa veja Lent \& Wygodzinsky (1979).

Material tipo: de $P$. megistus, desconhecido; de C. porrigens, depositado no British Museum (Natural History), Londres, Inglaterra; de T. wernickei, depositado no Instituto Bacteriológico, Buenos Aires, Argentina; de T. africana no Zoologisches Museum, Berlim, Alemanha.

Habitat: diversas palmeiras, refúgios de roedores, edentados, marsupiais e morcegos, ninhos de aves, ocos de árvores, galinheiros, domicílios e diversas estruturas peridomiciliares (Carcavallo et al. 1998).

Curiosidades: foi nessa espécie que Carlos Chagas encontrou o Trypanosoma cruzi.

Distribuição: Alagoas, Bahia, Ceará, Distrito Federal, Espírito Santo, Goiás, Maranhão, Mato Grosso do Sul, Mato Grosso, Minas Gerais, Pará (registro histórico, a espécie não foi mas capturada neste estado), Paraíba, Paraná, Pernambuco, Piauí, Rio de Janeiro, Rio Grande do Norte, Rio Grande do Sul, Santa Catarina, São Paulo, Sergipe e Tocantins.

Distribuição fora do Brasil: Argentina, Bolívia, Paraguai e Uruguai. 


\section{Panstrongylus rufotuberculatus (Champion, 1899)}

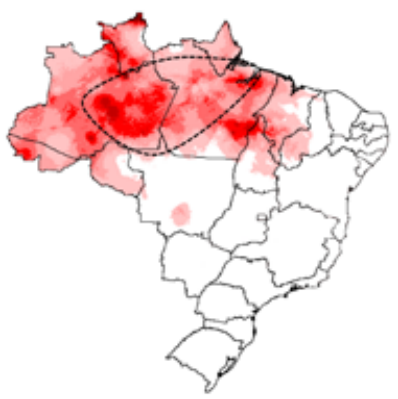

Etimiologia: o epíteto específico rufotuberculatus é uma referência a coloração vermelho ferrugem do inseto (na descrição original citado como "rufo-ferruginous"), vem do latim "rufus", "rufa" que significa vermeIho, avermelhado.

Sinônimos: Lamus rufotuberculatus Champion, 1899; Triatoma rufotuberculata Neiva, 1914; Triatoma coxo-rufa Campos, 1932; Mestor rufotuberculatus Usinger, 1939

Características gerais: comprimento dos machos de 24 a $27 \mathrm{~mm}$, das fêmeas de 25 a $28 \mathrm{~mm}$. Coloração geral marrom escuro ou negro com manchas marrom amarelado na cabeça, pescoço, tórax, pernas e abdômen. Hemiélitro com manchas marrom escuro e verde pálido. Tegumento do corpo e superfície dorsal com cerdas douradas. Cabeça enegrecida incluindo os tubérculos anteníferos, genas, búcula e toda a superfície inferior da cabeça. Clípeo avermelhado, negro somente na base; superfície dorsal da cabeça com longa mancha avermelhada em forma de Y. Cabeça curta e larga, consideravelmente mais curta que o pronoto (1: 1,15-1,45), com superfície rugosa; proporção entre o comprimento da cabeça e a largura ao nível dos olhos = 1:0,65-0,80. Região anteocular três a quatro vezes mais longa que a pós-ocular (1: 0,25-0,35). Genas não alcançando o ápice do clípeo. Olhos grandes, em vista lateral ultrapassam o nível da superfície inferior da cabeça, mas não a superior. Proporção entre a largura de um olho e a região interocular = 1: 1,30-1,85. Tubérculos anteníferos com processo apicolateral obsoleto.

Antenas com primeiro e segundo artículos negros. Primeiro artículo ultrapassando ligeiramente o ápice do clípeo. Proporções entre os artículos antenais = $1: 3,0-3,5: 2,2-2,8: 1,9-2,3$. Rostro com primeiro e segundo segmentos negros, terceiro marrom avermelhado. Proporções entre os segmentos do rostro = 1:1,9-2,2: 0,6-0,7. Pronoto de coloração marrom escuro a negro. Lobo anterior negro com projeções ântero-laterais, tubérculos discais e laterais vermelhos. Ângulos humerais salientes, ângulos ântero-laterais pronunciados e lateralmente direcionados. Esterno e pleura negros, acetábulo avermelhado. Escutelo negro com processo apical vermelho e mais curto que o corpo principal. Hemiélitro marrom claro, nitidamente com coloração verde claro. Cório riscado de marrom principalmente ao longo das veias; membrana com pontos negros. Pernas robustas, de coloração marrom escuro ou preta. Fêmures dianteiros e medianos com três ou quatro dentículos curtos, raramente somente dois; dorsalmente com faixas vermelhas longitudinais de extensão variada e anel apical vermelho. Fossetas esponjosas presentes nas tíbias anteriores e medianas dos machos, ausentes nas fêmeas. Conexivo com mancha negra sub-retangular situada no centro de cada segmento, alcançando a margem externa. Placas conexivais com faixa negra adjacente a sutura intersegmental. Para descrição completa veja Lent \& Wygodzinsky (1979). 
Material tipo: de M. rufotuberculatus depositado no British Museum (Natural History), Londres, Inglaterra; de $T$. coxo-rufa, desconhecido.

Habitat: palmeiras, árvores ocas, refúgios de mamíferos como tatus e morcegos, eventualmente nos domicílios e peridomicílios (Carcavallo et al. 1998).

Curiosidades: única espécie de barbeiro com coloração esverdeada.

Distribuição: Amazonas, Pará, Mato Grosso.

Distribuição fora do Brasil: Argentina, Bolívia, Colômbia, Costa Rica, Equador, Guiana Francesa, México, Panamá, Peru e Venezuela. 


\section{Panstrongylus}

\section{tupynambai Lent, 1942}

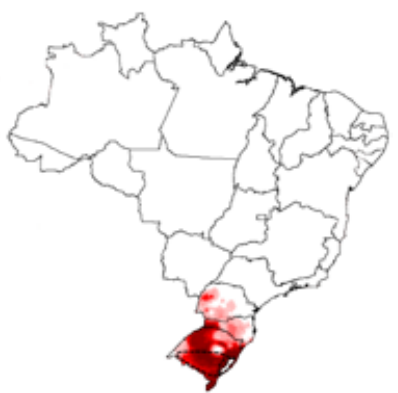

Etimologia: o epíteto específico tupynambai é uma homenagem a Antonio A. Tupynambá que coletou a espécie.

Características gerais: Comprimento dos machos $22 \mathrm{~mm}$, das fêmeas $25 \mathrm{~mm}$. Coloração geral marrom avermelhado, com áreas marrom escuro no pronoto, cório e conexivo. Primeiro artículo antenal ultrapassando ligeiramente o nível do ápice do clípeo. Proporções entre os artículo antenais = 1:3:2,3:1,9. Primeiro segmento do rostro tão longo ou ligeiramente mais longo que o segundo, segundo segmento atingindo o nível do meio do pescoço. Proporções entre os segmentos rostrais $=1: 0,9-1,0: 0,4$. Pronoto com colar e lobo anterior marrom avermelhado ou marrom escuro. Lobo posterior marrom avermelhado, com área marrom escuro na metade do espaço entre as carenas submedianas; $1+1$ marcas escuras largas no espaço entre as carenas submedianas e laterais. Tubérculos discais visíveis, mas não grandes, arredondados; tubérculos laterais menores, apenas elevações da carena lateral. Carena submediana baixa, evanescente no terço posterior do lobo posterior do pronoto. Ângulos humerais arredondados. Ângulos ântero-laterais curtos e arredondados. Escutelo marrom escuro, processo apical marrom escuro ou negro e quase tão longo quanto o corpo principal do escutelo. Hemiélitro do macho atingindo o ápice do abdômen, mas somente o meio do VII urotergito na fêmea. Cório marrom avermelhado escuro, marrom avermelhado claro na base. Ápice do cório quase negro. Membrana marrom escuro. Perna marrom avermelhado. Fêmures anteriores e medianos com um par de dentículos subapicais, e 0-2 dentículos menores mais abaixo. Machos com fossetas esponjosas muito pequenas nas tíbias anteriores e medianas, ausentes nas fêmeas. Conexivo e abdômen ventral marrom avermelhado. Para descrição completa veja Lent \& Wygodzinsky (1979).

Material tipo: depositado na Coleção Herman Lent do Instituto Oswaldo Cruz, Rio de Janeiro.

Habitat: pedregais, refúgios de roedores, ocasionalmente em peridomicílios e domicílios (Carcavallo et al. 1998).

Curiosidades: difere de todas as demais espécies de Panstrongylus por possuir o primeiro segmento do rostro tão longo, ou ligeiramente mais longo, que o segundo.

Distribuição: Rio Grande do Sul.

Distribuição fora do Brasil: Uruguai. 


\section{Parabelminus carioca}

\section{Lent, 1943}

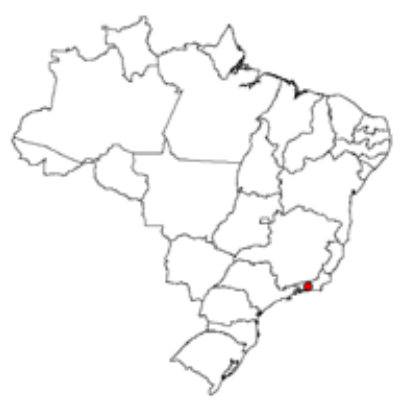

Etimologia: o nome genérico Parabelminus vem do grego "para" que significa próximo, uma referência à similaridade com as espécies do gênero Belminus. $\mathrm{O}$ epíteto específico carioca é uma referência fato da espécie ter sido encontrada na cidade do Rio de Janeiro.

Características gerais: Comprimento dos machos de 9,0 a 9,5 mm, das fêmeas de $10 \mathrm{~mm}$. Coloração geral negra, antena marrom; hemiélitro com manchas amareladas na base da membrana e adjacente ao cório. Cabeça quase duas vezes mais longa que larga $(1: 0,5-0,6)$ e tão longa quanto o pronoto $(1: 0,9-1,0)$; região anteocular nitidamente mais longa que a pós-ocular $(1: 0,7)$. Região interocular duas vezes, ou mais larga que a largura de um olho $(1: 2,5-2,7)$. Proporções entre os artículos antenais $=1: 2,3: 2,4: 3,0$. Proporções entre os artículos do rostro $=1: 2,8: 0,9$. Pronoto com constrição entre os lobos anterior e posterior não muito pronunciado. Ângulos ântero-laterais do pronoto pouco pronunciados. Escutelo sem processo apical. Hemiélitro não alcançando o ápice do abdômen em ambos os sexos, coloração geral negra com áreas muito claras no espaço entre a veia Cu e a sutura claval, nas bases das células internas e externas da membrana, ou somente da célula interna, na membrana adjacente a base célula interna, e na área adjacente ao ápice do cório. Ápice do hemiélitro ultrapassando ligeiramente a base do sétimo tergito abdominal, ficando distante do ápice do abdômen em ambos os sexos. Pernas curtas, granulosas, fêmures robustos com 1+1 dentículos curtos localizados subapicalmente na superfície ventral. Abdômen de coloração igual à do resto do corpo. Fossetas esponjosas presentes nos três pares de pernas. Ângulos póstero-laterais dos segmentos conexivais com pequenas manchas avermelhadas. Para descrição completa veja Lent \& Wygodzinsky (1979).

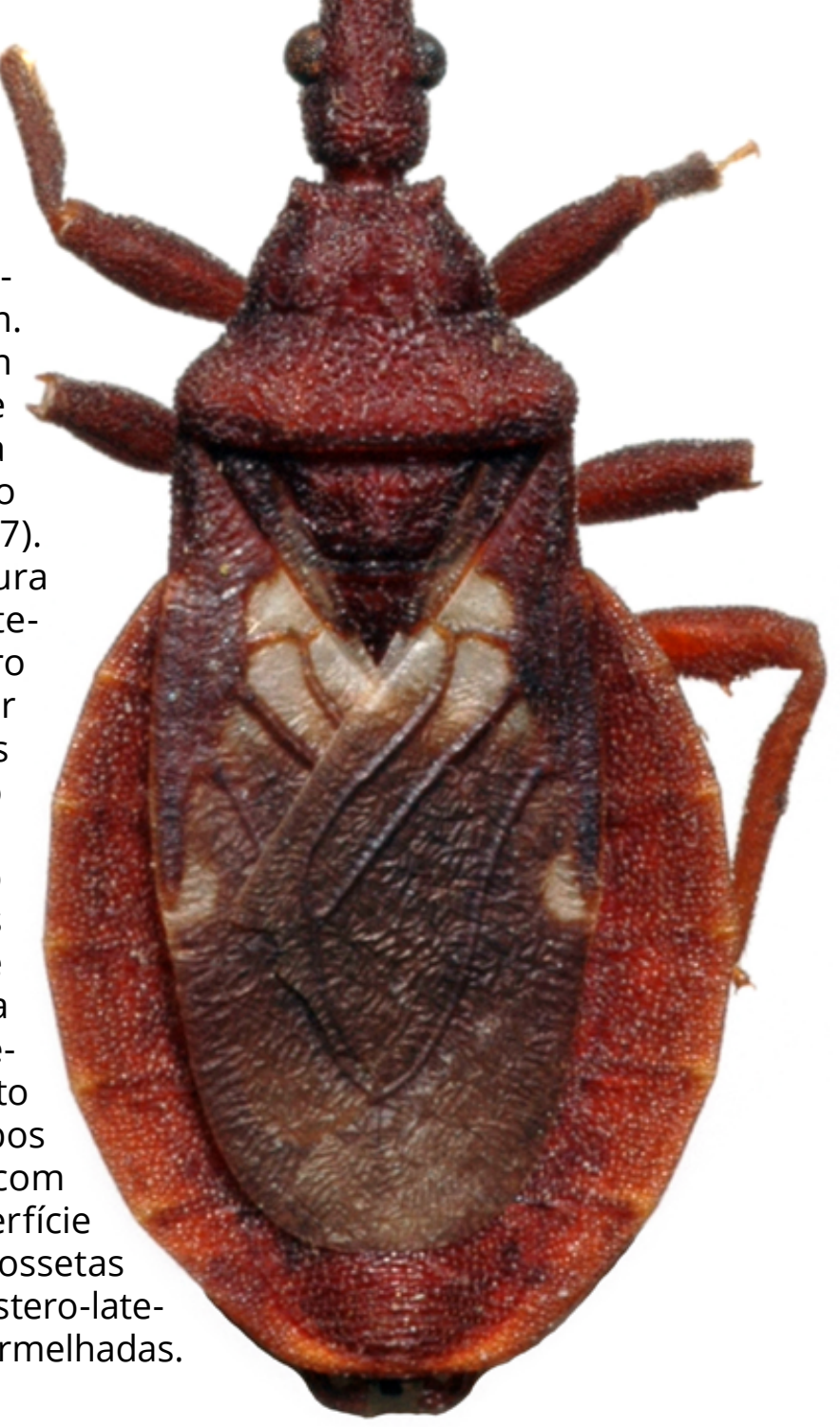

Material tipo: depositado na Coleção Herman Lent do Instituto Oswaldo Cruz, Rio de Janeiro.

Habitat: encontrado entre as folhas de palmeiras (Attalea indaya) usadas como abrigos de gambás (Didelphis marsupialis) (Lent \& Wygodzinsky 1979).

Distribuição: Rio de Janeiro. 


\section{Parabelminus yurupucu Lent \& Wygodzinsky, 1979}

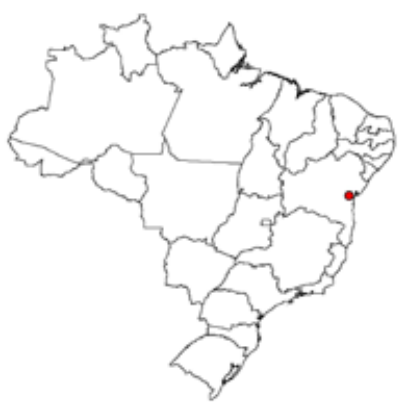

Etimologia: o epíteto específico yurupucu é derivado do Guarani e significa nariz longo.

Características gerais: comprimento total dos machos de 8 a $9 \mathrm{~mm}$, das fêmeas de 9,5 a $9,7 \mathrm{~mm}$. Coloração geral negra, antena marrom; hemiélitro com manchas amareladas na base da membrana e adjacente ao cório. Cabeça duas vezes mais longa que larga $(1: 0,5)$, distintamente mais

longa que o pronoto $(1: 0,8-0,9)$; região anteocular quase duas vezes mais longa que a pós-ocular (1:0,60-0,65). Proporção entre a largura de um olho e a região interocular $=1: 1,65-1,85$. Proporções entre os artículos antenais = 1:1,75-1,80:1,85-2,10:2,00. Rostro longo e delicado, proporções entre os segmentos rostrais $=1: 2,40-2,80: 0,80-0,85$. Pronoto em forma de sino com constrição mediana pronunciada, bordos dos lobos anterior e posterior formando nitidamente um ângulo. Ângulos ântero-laterais do pronoto arredondados abruptamente. Escutelo sem processo apical. Hemiélitro não alcançando o ápice do abdômen em ambos os sexos, coloração geral negra com áreas claras no espaço entre a veia Cu e a sutura claval, nas bases das células internas e externas da membrana, ou somente da célula interna, na membrana adjacente à base célula interna, e na área adjacente ao ápice do cório. Ápice do hemiélitro ultrapassando ligeiramente a base do sétimo tergito abdominal, ficando distante do ápice do abdômen em ambos os sexos. Fêmures anteriores com cerca de três vezes e meia mais longos que largos, com um par de dentículos curtos; fêmures medianos e posteriores com um par de processos espinhosos cada. Abdômen de coloração igual à do resto do corpo. Para descrição completa veja Lent \& Wygodzinsky (1979).

Material tipo: depositado na Coleção Herman Lent do Instituto Oswaldo Cruz, Rio de Janeiro.

Habitat: bromélias e troncos de árvores com ninhos de roedores encontrada associada com Triatoma tibiamaculata e Rhodnius domesticus (Lent \& Wygodzinsky, 1979).

Distribuição: Bahia. 


\section{Psammolestes coreodes Bergroth, 1911}

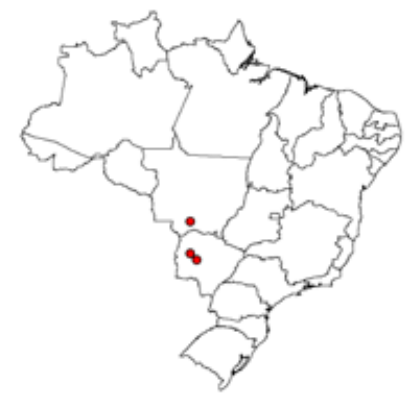

Etimologia: O nome genérico Psammolestes vem do grego "psammos" que significa areia, uma clara referência a coloração dos integrantes do gênero. O termo grego "lestes" significa predador, uma referência aos hábitos dos integrantes da família Reduviidae na qual o gênero foi inserido. O epíteto específico coreodes faz referência ao fato do autor ter considerado o inseto tão similar a hemípteros da família Coreidae que inicialmente o manteve guardado junto com insetos dessa família.

Características gerais: comprimento total dos machos de 12 a $14 \mathrm{~mm}$, das fêmeas de 13,5 a $15 \mathrm{~mm}$. Coloração geral marrom amarelada com áreas irregularmente manchadas de marrom escuro ou negro. Tegumento rugoso com cerdas curtas e douradas. Cabeça tão longa ou ligeiramente mais longa que larga (1:0,8-1), distintamente mais curta que o pronoto $(1: 1,2-1,3)$; de coloração amarelada e irregularmente manchada de marrom escuro. Região anteocular duas vezes mais longa que a pós-ocular (1:0,45-0,5). Clípeo ligeiramente alargado anteriormente. Genas visíveis, fortemente divergentes, ultrapassando consideravelmente o clípeo. Olhos grandes, em vista lateral podem alcançar, mas não ultrapassar a face ventral da cabeça. Proporção entre a largura de um olho e a região interocular=1:1,60-1,65. Ocelos inseridos em nítidas elevações. Antenas amareladas, manchadas com negro; segundo artículo negro no ápice, terceiro escurecido submedianamente. Proporções entre os artículos antenais $=1: 3,3-4,4: 3,5-4,5: 2,5-3,1$. Proporções entre os segmentos do rostro $=1: 2,1-2,3: 0,9-1,0$. Segundo e terceiro segmentos rostrais com longas cerdas. Ângulos ântero-laterais do pronoto curtos, não atingindo o nível dos ocelos, aplainados e acuminados com pequenas áreas negras. Lobo posterior do pronoto irregularmente rugoso. Escutelo rugoso transversalmente, processo apical se estreitando apicalmente. Hemiélitro da mesma coloração do corpo, células da membrana distintamente escurecidas. Hemiélitros dos machos atingindo do ápice do abdômen, enquanto o das fêmeas apenas se aproxima. Pernas de cor marrom claro, com manchas marrom escuras irregularmente espalhadas. Abdômen ventral marrom amarelado, irregularmente reticulado com manchas negras e com filas de manchas escuras longitudinais. Segmentos conexivais amarelados, geralmente com duas distintas marcas marrom escuro ao longo da margem lateral. Para descrição completa veja Lent \& Wygodzinsky (1979).

Material tipo: depositado no Universitetets Zoologiska Museum, Helsinki, Finlândia. 
Habitat: ninhos de Phacellodomus sibilatrix Sclater (Furnariidae), Myiopsitta monacha cotorra (Psittacidae), Pseudoseisura lophotes (Furnariidae) e outras aves não identificadas. Também foi encontrada sob cascas da árvore "quebracho colorado" (Lent \& Wygodzinsky 1979).

Curiosidades: seus ovos são postos isoladamente mas aderem ao substrato.

Distribuição: Mato Grosso e Mato Grosso do Sul.

Distribuição fora do Brasil: Argentina, Bolívia e Paraguai. 


\section{Psammolestes tertius Lent \& Jurberg, 1965}

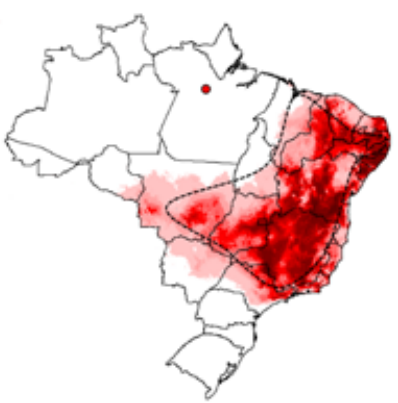

Etimologia: o epíteto específico tertius vem do latim "terti" que significa terceiro, uma referência ao fato dessa ter sido a terceira espécie do gênero a ser descrita.

Características gerais: Comprimento total dos machos de 11,5 a 12,5 mm, das fêmeas de 12,5 a 13,5 mm.Coloração geral marrom amarelada com áreas irregularmente manchadas de marrom escuro ou negro. Tegumento rugoso com cerdas curtas e douradas. Cabeça ligeiramente mais longa que larga $(1: 0,88-0,95)$ e de ligeiramente a distintamente mais curta que o pronoto $(1: 1,05-1,2)$; coloração marrom amarelada dorsalmente com manchas escuras distribuídas irregularmente. Região anteocular de duas a duas vezes e meia, mais longa que a pós-ocular (1:0,4-0,5). Clípeo ligeiramente alargado anteriormente. Genas visíveis, fortemente divergentes, ultrapassando consideravelmente o clípeo. Olhos grandes, em vista lateral podem alcançando o nível da superfície ventral da cabeça e se aproximando do nível da superfície dorsal. Proporção entre a largura de um olho e a região interocular $=1: 1,5-1,6$. Ocelos inseridos em nítidas elevações (um pouco menos proeminentes que em $P$. coreodes). Proporções entre os artículos antenais $=1: 4,3-6,3: 4,1-5,2: 3,1-3,6$. Proporções entre os segmentos do rostro $=1: 2,0-2,3: 0,85-1,0$. Segundo e terceiro segmentos rostrais com longas cerdas. Pronoto com numerosas manchas escuras no lobo anterior. Ângulos ântero-laterais do pronoto muito curtos, não proeminentes. Escutelo rugoso transversalmente, processo apical afilando para o ápice. Hemiélitro atingindo o ápice do abdômen em ambos os sexos, de cor de corpo geral, com celas da membrana distintamente escurecidas. Pernas da cor do corpo, com manchas marrom escuras irregularmente espalhadas. Abdômen e conexivo como em $P$. coreodes. Para descrição completa veja Lent \& Wygodzinsky (1979).

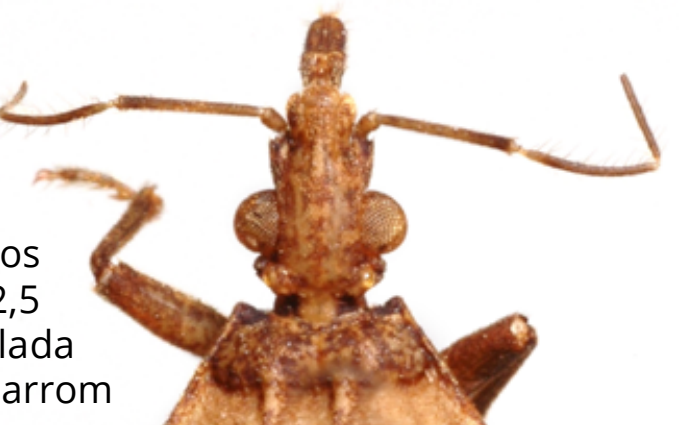

Material tipo: depositado na Coleção Herman Lent do Instituto Oswaldo Cruz, Rio de Janeiro

Habitat: essa espécie é encontrada frequentemente em ninhos de aves da família Furnariidae: Phacellodomus rufifrons rufifrons, P. rufifrons specularis e Anumbius annumbi; conhecidas regionalmente como João graveto, João tenenem, cochicho, titiri e casaca-de-couro. Também foi encontrada em ninhos de Mimus saturninus (Mimidae) e P. ruber (Furnariidae) localizado em palmeiras buriti e sobre a casca de jaqueira (Artocarpus heterophyllus) (Moraceae) (Lent \& Wygodzinsky 1979, Gurgel-Gonçalves \& Cuba 2007).

Curiosidades: essa espécie põe seus ovos aderidos aos gravetos usados pelas aves para construir seus ninhos cuja coloração críptica torna difícil sua percepção.

Distribuição: Alagoas, Bahia, Ceará, Distrito Federal, Goiás, Mato Grosso, Maranhão, Minas Gerais, Pará (um registro, a espécie não foi mais capturada neste estado. A ocorrência ocasional poderia ser resultante de dispersão passiva por pássaros), Paraíba, Pernambuco, Piauí, São Paulo e Tocantins.

Distribuição fora do Brasil: Peru (Cabrera 2006). 


\section{Rhodnius amazonicus Almeida, Santos \& Sposina, 1973}

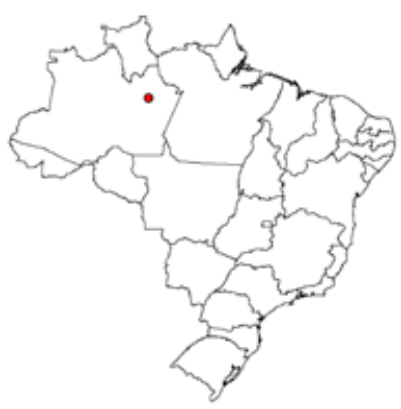

Etimologia: o nome genérico Rhodnius vem do grego "rhodo, rhodum" que significa rosa, avermelhado, uma referência à coloração desses insetos. $\mathrm{O}$ epíteto específico amazonicus é uma referência à região onde os espécimes foram coletados.

Características gerais: Comprimento total dos machos 16,5 mm, da fêmea $17 \mathrm{~mm}$. Coloração geral marrom amarelada, com manchas escuras dispersas. Cabeça ligeiramente granulosa, ventralmente de coloração marrom, dorsalmente a região anteocular é marrom escuro com uma faixa marrom amarelada. Antenas com primeiro artículo marrom, segundo artículo antenal amarelo na base e marrom na metade apical, (terceiro e quarto artículos do macho examinado faltando). Região pós-ocular amarelada com duas faixas negras da margem posterior dos olhos até a base do pescoço. Rostro marrom. Margens anterior e lateral do pronoto com carenas amareladas. Lobo anterior do pronoto com seis faixas escuras irregulares; lobo posterior granuloso, com seis faixas escuras longitudinais e $1+1$ carenas submedianas amareladas. Pleura uniformemente escura. Escutelo com uma depressão mediana negra, margeada por duas faixas marrons, processo apical do escutelo amarelo no ápice. Cório uniformemente escuro com veias amarelas. Membrana marrom, não alcançando o bordo posterior do abdômen. Fêmures negros com uma discreta anelação amarelada na região mediana dos fêmures posteriores. Tíbias amareladas com um anel negro na região mediana. Conexivo amarelo com uma mancha negra triangular em cada segmento. Para descrição completa veja Almeida, Santos \& Sposina (1973) e Bérenger \& Pluot-Sigwalt (2002)

Material tipo: depositado no Instituto Nacional de Pesquisas da Amazônia, Manaus; no Muséum National d'Histoire Naturelle, Paris, França e na coleção particular de JM Bérenger.

Habitat: Desconhecido, os únicos espécimes conhecidos foram capturados em armadilhas luminosas e sua biologia é desconhecida (Bérenger \& Pluot-Sigwalt 2002).

Curiosidades: espécie muito similar a Rhodnius pictipes da qual foi considerada sinônimo por 29 anos.

Distribuição: Amazonas.

Distribuição fora do Brasil: Guiana Francesa (Cacao, Saul). 


\section{Rhodnius brethesi} Matta, 1919

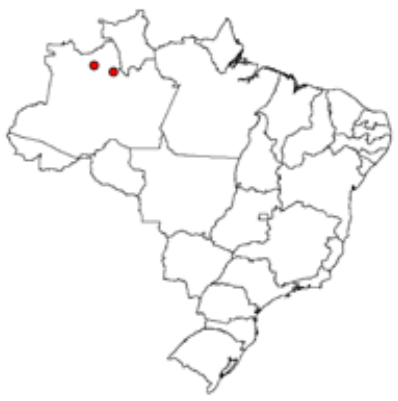

Etimologia: o epíteto específico brethesi é uma homenagem ao entomólogo francês Jean Brèthes (1871-1928) que trabalhou no Museo Argentino de Ciencias Naturales.

Características gerais: comprimento total dos machos de 19 a 19, 5 mm, das fêmeas de 19 a 20 mm. Coloração geral marrom escuro a negro, com manchas claras e faixas na superfície dorsal de cabeça e pescoço, pronoto, escutelo, hemiélitro, conexivo e superfície ventral do abdômen. Cabeça granulosa, negra, com faixa longitudinal dorsal estreita amarelada. Cabeça duas vezes mais longa que larga na altura dos olhos $(1: 0,45-0,50)$ e distintamente mais longa que o pronoto $(1: 0,75-0,80)$. Região anteocular de três a quatro vezes mais longa que a pós-ocular (1:0,25$0,30)$. Olhos grandes, atingindo o nível da superfície ventral da cabeça e quase alcançando o nível da superfície dorsal. Proporção entre largura de um olho e região interocular $=1: 0,60-0,85$. Antenas negras; Proporções entre os artículos antenais = 1:4,5-5,5:6,07,3:3,9-4,1. Primeiro segmento do rostro atingindo o nível da inserção da antena, segundo ultrapassando o nível dos ocelos; terceiro curto. Proporções entre os segmentos do rostro $=1: 3,6-3,9: 0,9-1,0$. Pescoço negro com faixa clara longitudinal ao longo do centro. Pronoto negro com 1+1 faixas submedianas claras,

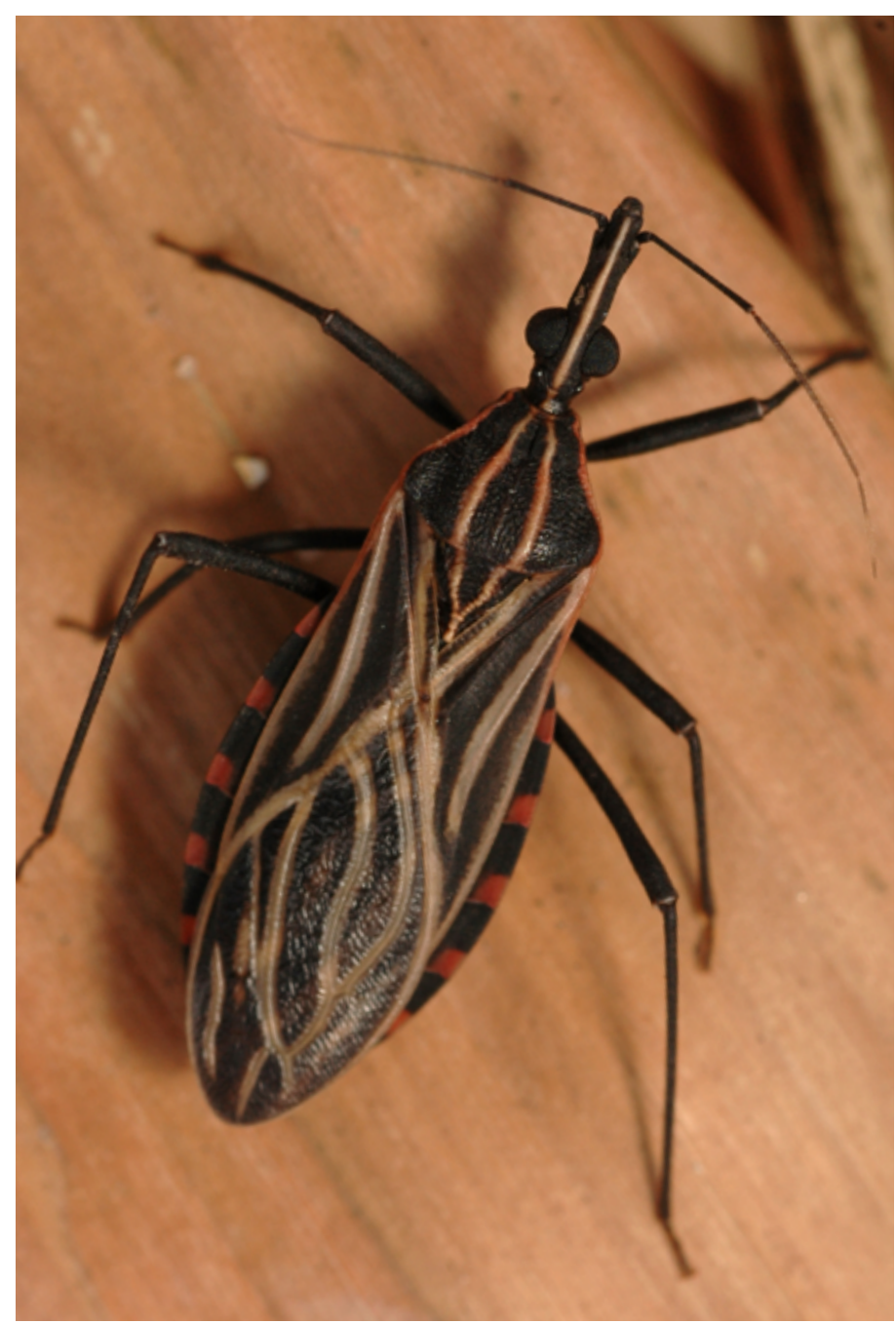
estendendo-se do colar, sobre as carenas submedia-

nas, até o bordo do lobo posterior do pronoto; faixas essas que dividem o pronoto em três áreas negras. Bordos laterais do pronoto castanho claro desde o ápice dos ângulos ântero-laterais até o húmero. Escutelo negro com 1+1 carenas de cor castanho claro unidas no ápice do processo escutelar. Pernas totalmente negras, esguias; fêmures dianteiros cerca de seis vezes mais longos que largos. Conexivo dorsal e ventral negro, a metade posterior de cada segmento apresenta uma mancha retangular laranja ou avermelhada. Hemiélitro marrom escuro ou negro com veias incluídas em faixas claras. Para descrição completa veja Lent \& Wygodzinsky (1979).

Material tipo: desconhecido.

Habitat: espécie associada a palmeiras, especialmente Leopoldina piassaba.

Curiosidades: segundo alguns autores a espécie pode ser muito agressiva atacando os trabalhadores que coletam as fibras da piaçava em plena luz do dia (Coura et al. 1994).

Distribuição: Amazonas.

Distribuição fora do Brasil: Venezuela. 


\section{Rhodnius domesticus Neiva}

\section{\& Pinto, 1923}

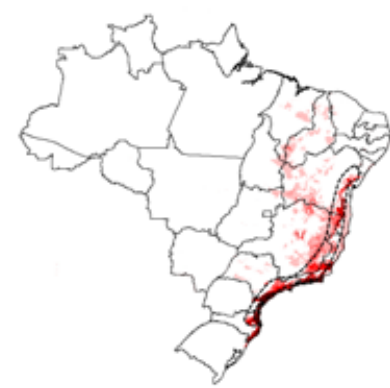

Etimologia: o epíteto específico domesticus é uma referência ao fato de ter sido encontrada em domicílio, entretanto, é importante ressaltar que até hoje não há relatos de colônias domiciliares dessa espécie.

Características gerais: comprimento total dos machos de 15 a 17 mm, das fêmeas de 16,5 a 18 $\mathrm{mm}$. Coloração geral marrom alaranjado com manchas mais escuras em várias áreas do corpo e apêndices. Cabeça escura com a região dorsal mais clara longitudinalmente, cerca de duas vezes e meio mais longa que larga, ao nível dos olhos (1:0,5), e tão longa ou ligeiramente mais longa que o pronoto $(1: 0,95: 1,0)$. Região anteocular de duas e meia a três vezes mais longa que a pós-ocular (1:0,3-0,4). Olhos de tamanho médio, em vista lateral atingindo o nível da superfície ventral da cabeça, mas não o nível da superfície dorsal. Proporção entre largura de um olho e região interocular =1:1,3-1,5. Antenas com segundo artículo marrom tornando-se negro em direção ao ápice; terceiro artículo com a metade basal negra e a apical esbranquiçada ou amarelada; quarto artículo amarelo com a ponta escura. Proporções entre os artículos antenais = 1:5,7-5,8:3,5-4,0:2,3-2,5. Segundo segmento rostral atingindo o pescoço; proporções entre os segmentos do rostro $=1: 2,8-3,0: 1,0$. Pronoto com carenas submedianas de coloração amarelo luminoso. Cor do lobo anterior marrom avermelhado. Ângulos ântero-laterais não proeminentes. Escutelo negro com $1+1$ carenas claras. Hemiélitro cor de palha com cório marrom avermelhado e membrana fracamente pigmentada. Pernas estreitas com coxas, trocânteres e fêmures uniformemente castanho escuro, tíbias castanho com anelação apical escura. Conexivo com segmentos dorsais com mancha marrom avermelhada na metade anterior.Para descrição completa veja Lent \& Wygodzinsky (1979).

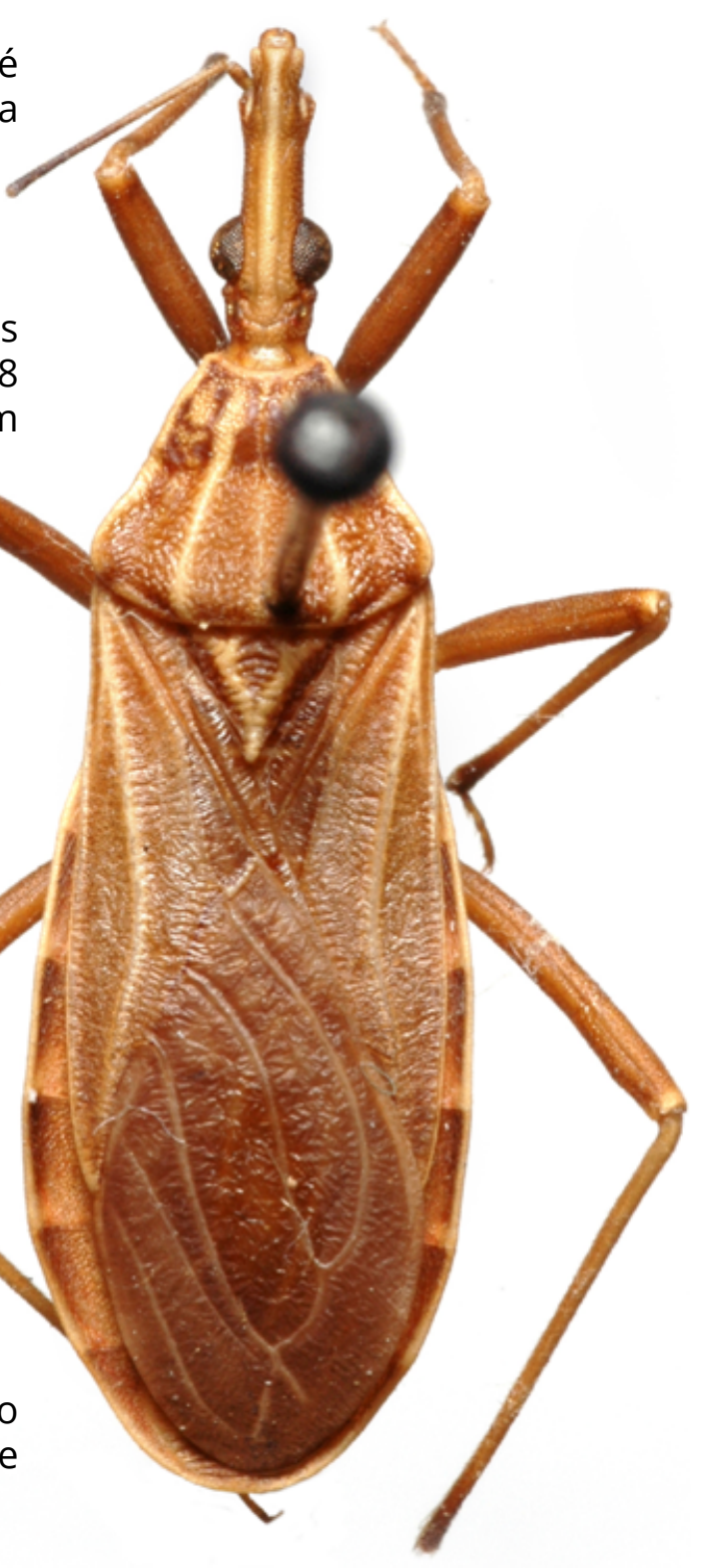

Material tipo: depositado na Coleção Herman Lent do Instituto Oswaldo Cruz, Rio de Janeiro.

Habitat: Bromélias, ninhos de roedores, refúgios de marsupiais, ocos de árvores ocas e palmeiras (Carcavallo et al. 1998).

Curiosidades: apesar do seu nome, é uma espécie silvestre da mata atlântica do Brasil, raramente encontrada em domicílios.

Distribuição: Bahia, Espírito Santo, Minas Gerais, Rio de Janeiro, Paraná, Santa Catarina e São Paulo. 


\section{Rhodnius milesi Carcavallo, Rocha, Galvão \& Jurberg, 2001}

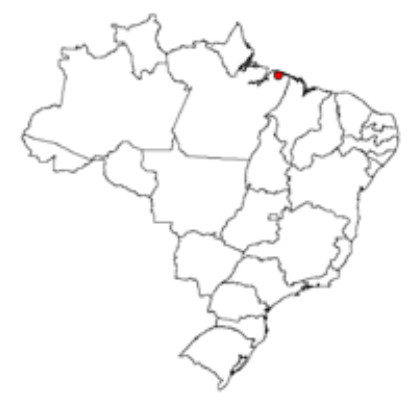

Etimologia: o epíteto específico milesi é uma homenagem a Michael A. Miles, parasitologista da London School of Hygiene and Tropical Medicine.

Características gerais: comprimento total dos machos de 19,5 a $20 \mathrm{~mm}$, das fêmeas $20 \mathrm{~mm}$. Coloração geral marrom escuro, com as seguintes áreas claras ou amareladas: a região central longitudinal da cabeça com duas bandas laterais pós-oculares, os bordos externos e as carenas paramedianas do pronoto. São de cor marrom mais clara que a cor geral as pernas e membranas dos hemiélitros. Cabeça três vezes mais longa que larga ao nível dos olhos. O comprimento da região anteocular é de 4,2 vezes a largura da mesma região em sua área mais estreita. A região anteocular é muito longa, cerca de 3,4 vezes mais longa que a pós-ocular. A região interocular é da mesma largura que um olho em vista dorsal (1:1). Genas ultrapassando o limite entre o clípeo e o anteclípeo. Tubérculo antenal divergente com um dentículo apical. Primeiro artículo antenal grosso e com cerdas escassas, preto igual ao segundo e a metade proximal do terceiro artículos; a metade distal do terceiro é progressivamente mais clara; o quarto é claro com exceção dos extremos que são escuros; proporções entre os artículos antenais $=1: 8,7: 3,5: 2,5$. Em vista lateral, os olhos não atingem o bordo superior da cabeça, mas ultrapassam o bordo inferior. O primeiro segmento do rostro atinge o início do tubérculo antenífero. Proporções entre os segmentos rostrais $=1: 3,5: 0,8$. Pronoto finamente granuloso, ângulos ântero-laterais pouco salientes. Não existem tubérculos discais nem laterais. Bordos laterais amarelos, assim como as duas faixas paramedianas que terminam no bordo posterior e continuam acompanhando com o desenho do escutelo. Ângulos humerais pouco salientes. Divisão entre os lobos anterior e posterior do pronoto pouco acentuada. Proesterno com sulco estridulatório profundo e muito estriado. Pernas com coxas amarelas, fêmures sem espinhos nem tubérculos subapicais, tíbias anteriores e medianas com fossetas esponjosas. Hemiélitros com as veias bem marcadas, no cório e na membrana e atingindo o bordo posterior do abdômen. Para descrição completa veja Valente et al. (2001).

Material tipo: depositado na Coleção Rodolfo Carcavallo do Instituto Oswaldo Cruz, Rio de Janeiro.

Habitat: palmeiras das espécies Maximiliana regia (Inajá) e Attalea speciosa (Babaçu). (Valente et al. 2001).

Distribuição: Pará. 


\section{Rhodnius montenegrensis Rosa et al., 2012}

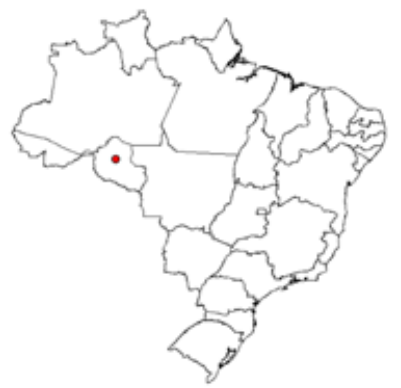

Etimologia: o epíteto específico montenegrensis é uma referência ao município de Montenegro, Estado de Rondônia, onde os espécimes foram coletados.

Características gerais: comprimento total dos machos $17,5 \mathrm{~mm}$, das fêmeas $21.54 \pm 0.75 \mathrm{~mm}$, largura do pronoto dos machos $3.99 \pm 0.32$ $\mathrm{mm}$, das fêmeas $4.54 \pm 0.26 \mathrm{~mm}$; largura do abdome dos machos $6.16 \pm 0.39$ $\mathrm{mm}$, das fêmeas $6.95 \pm 0.39 \mathrm{~mm}$.

Coloração geral amarela com listras longitudinais negras no pronoto, asas e conexivo. Cabeça sem manchas do clípeo ao pescoço, com uma faixa amarela central localizada entre duas $(1+1)$ faixas continua de cor marrom. Pernas amarelas, exceto a tíbia posterior com uma listra negra próxima ao tarso. Conexivo dorsal com mancha escura ocupando 1/3 de cada segmento. Bordos internos e externos, do conexivo, com uma faixa amarela descontinua. Para descrição completa veja Rosa et al. (2012).

Material tipo: depositado na Faculdade de $\mathrm{Ci}$ ências Farmacêuticas, UNESP, Araraquara, São Paulo.

Habitat: palmeiras da espécie Orbignya phalerata (babaçu).

Distribuição: Rondônia.

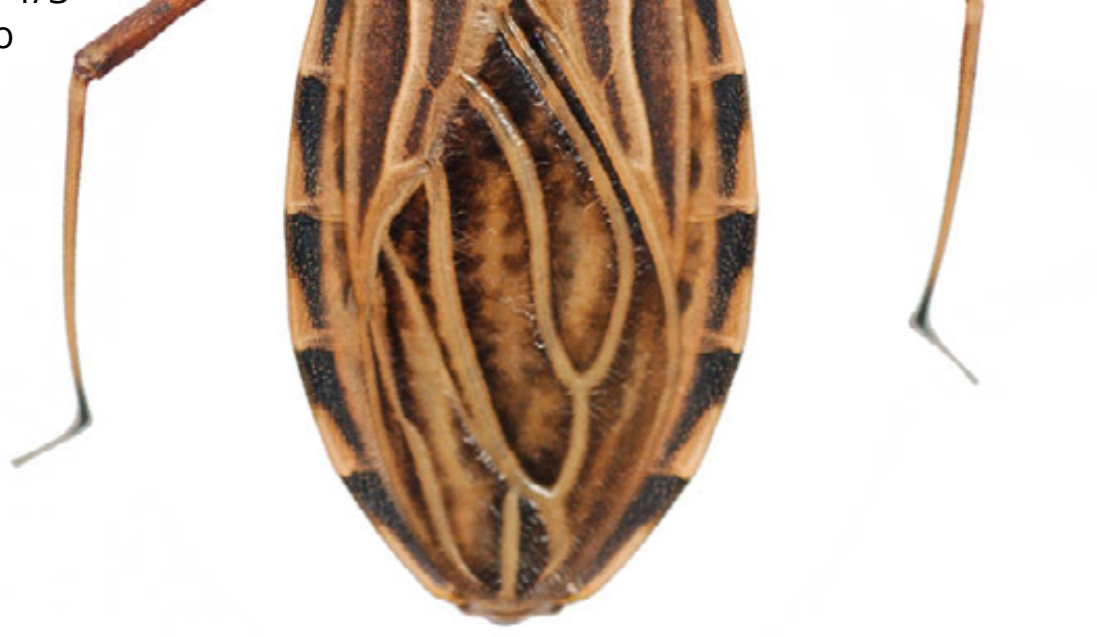




\section{Rhodnius nasutus}

\section{Stål, 1859}

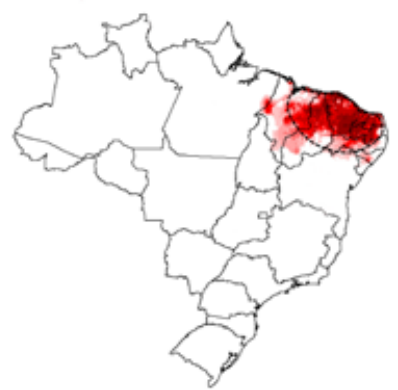

Etimologia: o epíteto específico nasutus vem do latim "nasutus", "nasuta", "nasutum" e significa nariz longo, uma referência a cabeça muito longa.

Sinônimos: Rhodnius brumpti Pinto, 1925

Características gerais: comprimento total dos machos de 12,5 a 16,5 mm, das fêmeas de 14 a $18 \mathrm{~mm}$. Coloração geral marrom amarelado, ligeiramente alaranjado, com manchas marrom escuro em algumas áreas do corpo e apêndices. Cabeça duas vezes e meia mais longa que larga ao nível dos olhos $(1: 0,35-0,40)$, distintamente mais longa que o pronoto (1:0,6-0,7). Região anteocular pouco mais de três vezes mais longa que a pós-ocular (1:0,3). Olhos de tamanho mediano, em vista lateral atingindo o nível da superfície ventral da cabeça, mas não a da superfície dorsal. Proporção entre a largura de um olho e a região interocular=1:1,2-1,3. Antenas de coloração marrom avermelhada, com o ápice do segundo e a metade apical do terceiro artículo mais escuros. Proporções entre os artículos antenais=1:6,2-7,0:3,2:2,5. Proporções entre os segmentos do rostro $=1: 3,4-3,7: 0,9-1,0$. Pronoto com o lobo anterior granuloso, e o posterior granuloso e rugoso, lobo posterior com área entre as carenas submedianas escura, fracamente subdivididas por uma faixa. As 1+1 áreas entre as carenas submedianas e o bordo lateral apresentam faixas escuras confluentes, formando uma área escura uniforme. Ângulos ântero-

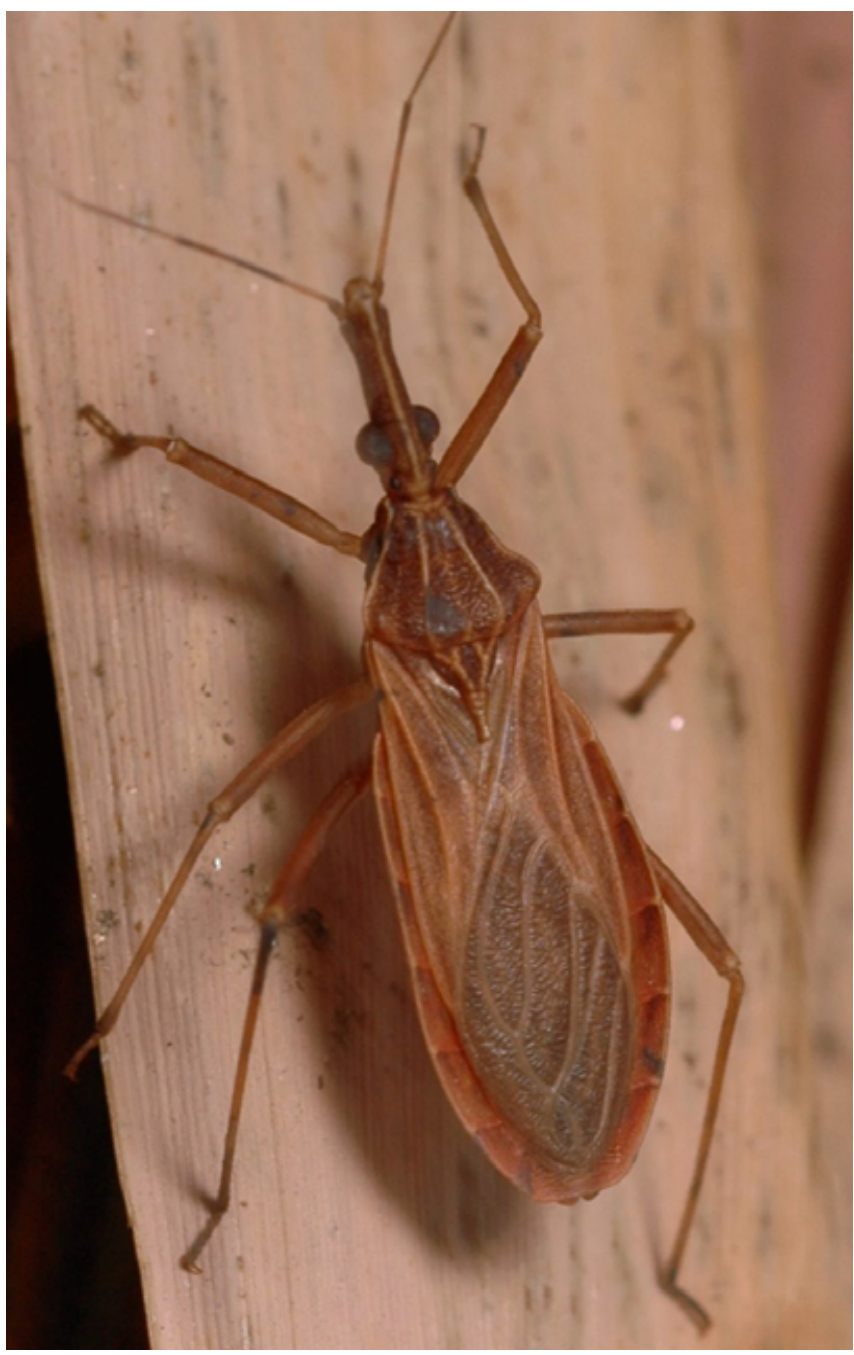
-laterais do pronoto angulosos. Escutelo escuro com 1+1 carenas claras bifurcadas anteriormente e fusionadas posteriormente. Hemiélitro marrom avermelhado com veias amarelo palha. Pernas uniformemente marrom avermelhadas e finas, fêmures anteriores seis vezes mais longos que largos. Abdômen marrom amarelado, quase sem manchas. Conexivo com manchas não muito nítidas na região ântero-lateral de cada segmento. Para descrição completa veja Lent \& Wygodzinsky (1979).

Material tipo: de R. nasutus depositado no Zoologisches Museum, Berlin, Alemanha; de R. brumpti depositado na Coleção Herman Lent do Instituto Oswaldo Cruz, Rio de Janeiro

Habitat: espécie associada a palmeiras, especialmente carnaúbas (Copernicia cerifera), mas pode também ser encontrada em outras espécies arbóreas da caatinga como Licania rigida, a oititica (Dias et al. 2008, Lima \& Sarquis 2008). Pode ser eventualmente encontrada em domicílios, mas vive principalmente em galinheiros.

Curiosidades: espécie com grande variabilidade cromática, com coloração variável de acordo com a espécie de palmeira habitada

Distribuição: Bahia, Ceará, Maranhão, Paraíba, Pernambuco, Piauí e Rio Grande do Norte. 


\section{Rhodnius neglectus Lent, 1954}

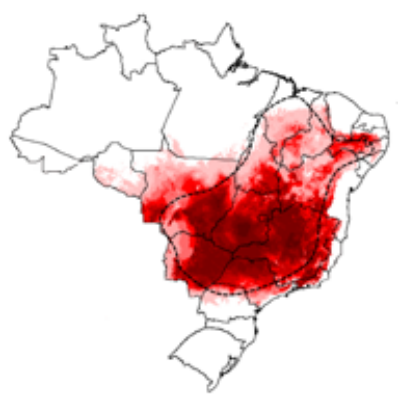

Etimologia: o epíteto específico neglectus vem do latim e significa negligenciado, uma referência ao fato dessa espécie ter permanecido desconhecida (negligenciada) por muitos anos.

Características gerais: comprimento total dos machos de 17,5 a $19 \mathrm{~mm}$, das fêmeas de 18,5 a 20,5 mm. Coloração geral marrom claro com marcas marrom escuro na cabeça, pronoto, escutelo, cório e conexivo e áreas amareladas ventralmente no abdômen, no conexivo, nas coxas e trocânteres. Cabeça fracamente granulosa, cerca de três vezes mais longa que larga ao nível dos olhos $(1: 0,35-0,40)$ e distintamente mais longa que o pronoto $(1: 0,75-0,80)$. Região anteocular pouco mais de três vezes mais longa que a pós-ocular (1:0,25-0,30). Olhos de tamanho mediano, em vista lateral atingindo o nível da superfície ventral da cabeça, mas não o da superfície dorsal. Proporção entre a largura de um olho e a região interocular = 1:0,95-1,20. Primeiro e segundo artículos antenais negros, terceiro negro na base e claro na metade apical, quarto escuro na base e no quarto apical. Proporções entre os artículos antenais $=1: 6,4-8,5: 3,4$ $4,0: 2,5-3,1$. Rostro com segundo segmento atingindo o pescoço. Proporções entre os segmentos do rostro $=1: 3,3-3,7: 0,8-0,9$. Pronoto com lobo anterior quase completamente liso, posterior rugoso-granuloso. Carena submediana amarelada, se estendendo do colar ao bordo posterior do pronoto, margens laterais do pronoto marrom amarelado claro, colorido da borda mais largo no lobo posterior do que no anterior. Áreas escuras entre as carenas confluentes nos dois terços anteriores. Ângulos ântero-laterais proeminentes. Escutelo com $2+2$ carenas curtas fundidas em $1+1$ carenas ao nível do terço anterior do escutelo e em uma única carena posteriormente. Hemiélitro marrom escuro com veias claras. Pernas marrom escuro; coxas, trocânteres e anel basal das tíbias amarelados. Abdômen com coloração geral marrom, mas com o centro dos urosternitos amarelo. Conexivo ventral estreitamente visível, dorsalmente com a metade ou os dois terços anteriores marrom, o resto amarelado. Para descrição completa veja Lent \& Wygodzinsky (1979).

Material tipo: depositado na Coleção Herman Lent do Instituto Oswaldo Cruz, Rio de Janeiro.

Habitat: espécie predominantemente silvestre, suas populações ocorrem frequentemente em palmeiras dos gêneros Attalea, Acrocomia e Mauritia mas podem também ser encontradas em ninhos de pássaros de Furnariidae (Phacellodomus), e de mamíferos como Didelphis. A invasão dos ambientes domiciliares já foi relatada diversas vezes (Silveira et al. 1984, Carcavallo et al. 1998, Gurgel-Gonçalves et al. 2004 Gurgel-Gonçalves \& Cuba Cuba 2007).

Curiosidades: espécie muito ativa e agressiva, nas colônias de laboratório move-se muito rapidamente.

Distribuição: Bahia, Distrito Federal, Goiás, Maranhão, Mato Grosso, Mato Grosso do Sul, Minas Gerais, Paraíba, Pernambuco, Paraná, Piauí, São Paulo e Tocantins. 


\section{Rhodnius paraensis Sherlock, Guitton \& Miles, 1977}

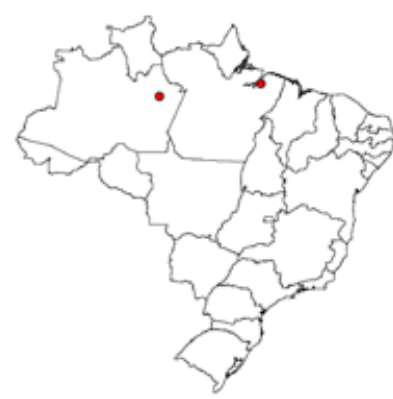

Etimologia: o epíteto específico paraensis e uma referência ao estado do Pará onde a espécie foi encontrada.

Características gerais: comprimento total dos machos de 10,5 a $11 \mathrm{~mm}$, das fêmeas de 10,8 a 12 mm. Coloração geral marrom claro com várias manchas marrom escuro no corpo e apêndices. Hemiélitro quase totalmente negro. Cabeça granulosa, especialmente nos lados; cor geral castanho claro, com anteclípeo, genas, tubérculos anteníferos, tubérculos ocelares castanho escuro, quase negro. Cabeça duas vezes mais longa que larga ao nível dos olhos $(1: 0,55)$ e tão longa quanto o pronoto. Região anteocular menos de duas vezes mais longa que a pós-ocular $(1: 0,65)$. Em vista lateral os olhos atingem o nível da superfície ventral da cabeça, mas não o da superfície dorsal. Proporção entre a largura de um olho e a região interocular = 1:1,55. Primeiro artículo antenal castanho amarelado; segundo artículo e três quintos basais do terceiro negros, porção apical do terceiro esbranquiçada; quarto branco com uma anelação basal escura. Artículos antenais comparativamente curtos e robustos, proporções entre os artículos antenais= 1:4,0:3,6:3,3. Segundo segmento rostral atingindo o nível do bordo posterior da cabeça. Proporções entre os segmentos do rostro = 1:2,7:0,9. Pescoço negro, castanho amarelado no centro e lateralmente. Pronoto castanho escuro com margens laterais claras e lobo posterior distintamente rugoso. Ângulos ântero-laterais do pronoto pouco destacados. Escutelo com 1+1 carenas claras fusionadas posteriormente em uma única carena. Hemiélitro castanho escuro. Pernas comparativamente curtas e robustas, castanho amareladas, com as seguintes áreas castanho escuro: coxas, um anel basal e um anal apical nos fêmures,ápice das tíbias anteriores e anelações submedianas e apicais nas tíbias medianas e posteriores. Fêmures fusiformes. Abdômen castanho amarelado ventralmente, irregularmente manchado de negro. Conexivo dorsal e ventral castanho escuro nos três quintos anteriores, contrastando com os dois quintos posteriores que são amarelados. Para descrição completa veja Lent \& Wygodzinsky (1979).

Material tipo: depositado na Coleção Herman Lent do Instituto Oswaldo Cruz, Rio de Janeiro.

Habitat: espécimes foram encontrados em ninhos do roedor Echimys chrysurus.

Curiosidades: a cabeça curta, as pernas robustas e as antenas igualmente curtas e robustas tornam essa espécie bem diferenciada das demais espécies do gênero. Se assumirmos o progressivo alongamento da cabeça e apêndices, comum as demais espécies do gênero, como uma condição derivada (novidade evolutiva), essa espécie poderia ser considerada a mais plesiomórfica (antiga) do gênero Rhodnius.

Distribuição: Amazonas e Pará

Distribuição fora do Brasil: Guiana Francesa. 


\section{Rhodnius pictipes Stål, 1872}

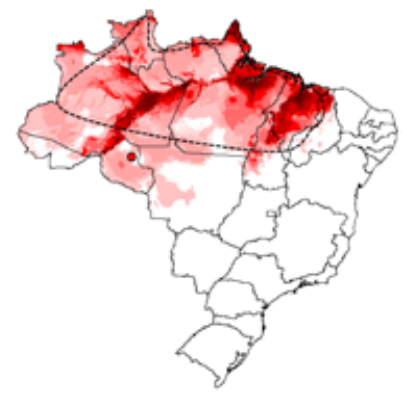

Etimologia: o epíteto específico pictipes vem do latim "pes" que significa pés e "pict" que significa pintado, uma referência às manchas negras presentes nas tíbias dos insetos.

Características gerais: comprimento dos machos de 18 a 20,5 mm, das fêmeas de 20 a $22 \mathrm{~mm}$. Coloração geral castanho amarelado com manchas castanho escuro em várias regiões do corpo e apêndices com aspecto geral mosqueado ou sarapintado. Cabeça granulosa cerca de duas vezes e meia mais longa que larga ao nível dos olhos (1:0,40-0,45), e distintamente mais longa que o pronoto $(1: 0,85-0,95)$. Região anteocular cerca de três vezes mais longa que a pós-ocular (1:0,30-0,35). Olhos em vista lateral atingindo o nível da superfície ventral da cabeça, mas não a dorsal. Proporção entre a largura de um olho e a região interocular $=1: 0,80$ 0,85 . Antenas com segundo segmento amarelo na base e negro na metade apical; terceiro artículo amarelo com anelação escura subbasal Proporções entre os artículos antenais = 1:5,9-6,3:3,9-4,7:2,6-3,1. Rostro com segundo segmento atingindo o pescoço, Proporções entre os segmentos do rostro $=1: 3,9$ 4,5:0,9-1,2. Pronoto com lobo posterior granuloso-rugoso; castanho escuro ou negro com granulações mais claras e aspecto geral mosqueado. Faixa longitudinal mediana, $1+1$ carenas submedianas e bordos laterais amarelados. Escutelo com $2+2$ carenas claras que se fundem em 1+1 na porção central do escutelo e numa única carena posteriormente. Hemiélitro de coloração amarelo-palha; cório com numerosas manchas negras irregulares; membrana com áreas intracelulares e extracelulares escuras. Pernas amareladas, coxas, trocânteres e especialmente os fêmures manchados de castanho escuro criando um aspecto mosqueado. Tíbias amareladas com anelação castanho escuro no terço basal e ápice. Abdômen castanho amarelado com manchas castanho escuro. Superfície dorsal do conexivo amarela; metade anterior de cada segmento formando uma mancha retangular escura com o centro e a lateral amarela, a mancha escura forma o desenho de uma ponta aguçada. Para descrição completa veja Lent \& Wygodzinsky (1979). Para comparação com $R$. stali veja Lent et al. (1993).

Material tipo: de R. pictipes depositado no Naturhistoriska Riksmuseet, Estocolmo, Suécia. De R. limosus depositado no British Museum (Natural History), Londres, Inglaterra.

Habitat: espécie silvestre encontrada principalmente em palmeiras e bromélias, entretanto, espécimes adultos são frequentemente encontrados em domicílios ou capturados próximos a fontes de luz. 
Curiosidades: em laboratório alguns espécimes exibem comportamentos peculiares: quando molestados "fingem" de mortos em uma variedade de posições incomuns e após o fim da sucção, se viram, elevam o abdômen e defecam diretamente sobre o local da picada. Estudos moleculares sugerem que $R$. pictipes abriga um complexo de espécies crípticas (Pavan 2009).

Distribuição: Amapá, Amazonas, Maranhão, Mato Grosso, Pará, Piauí, Roraima e Tocantins. Segundo Pavan (2009), espécimes encontrados em Rondônia podem ser de uma nova espécie afim de R. pictipes.

Distribuição fora do Brasil: Belize, Colômbia, Equador, Guiana, Guiana Francesa, Peru, Suriname, Trinidad e Venezuela. 


\section{Rhodnius robustus} Larrousse, 1927

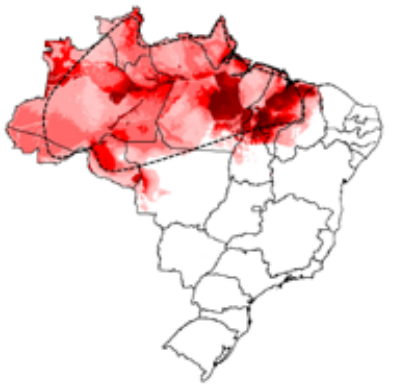

Etimologia: o epíteto específico robustus vem do latim "robustus", "robusta" que significa forte, robusto, uma referência ao tamanho da espécie, a maior do gênero Rhodnius.

Características gerais: comprimento dos machos de 20 a 23,5 mm, das fêmeas de 23 a $26 \mathrm{~mm}$. Coloração geral castanho amarelado com manchas castanho escuro em várias regiões do corpo e apêndices. Cabeça granulosa lateralmente e ventralmente, cerca de duas vezes e meia mais longa que larga ao nível dos olhos $(1: 0,4)$ e distintamente mais longa que o pronoto $(1: 0,7-0,8)$. Região anteocular aproximadamente quatro vezes mais longa que a pós-ocular (1:0,25). Olhos em vista lateral ultrapassando o nível da superfície ventral da cabeça, mas não a dorsal. Proporção entre a largura de um olho e a região interocular = 1:0, 75-1,0. Antenas com segundo artículo castanho escuro, terceiro amarelado, exceto pelo quarto basal castanho escuro; quarto claro. Proporções entre os artículos antenais = 1:7,6-10,2:5,4-6,3:3,4-4,4. Rostro com segundo artículo se estendendo além do nível dos ocelos, quase atingindo o pescoço. Proporções entre os segmentos do rostro $=1: 4,1-4,4: 0.9-1,0$. Pronoto com as carenas submedianas e as margens laterais castanho claro. Lobo posterior com as áreas escuras localizadas entre as carenas e entre as carenas e as margens laterais distintamente separadas por faixas amareladas. Ângulos ântero-laterais pouco proeminentes (menos proeminentes que em $R$. prolixus). Escutelo com $1+1$ carenas amareladas fusionadas posteriormente na base do processo apical. Hemiélitro castanho com veias muito nítidas.

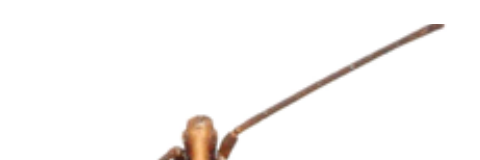
Pernas com coxas e trocânteres parcialmente ou inteiramente escuros; fêmures castanho avermelhado, tíbias de cor idêntica ou castanho amarelado escuro no ápice. Conexivo dorsal castanho amarelado, cada segmento com a mancha escura ocupando ao menos a metade anterior de cada segmento, com uma projeção pontuda posterior. Para descrição completa veja Lent \& Wygodzinsky (1979).

Material tipo: depositado na Faculté de Médécine, Paris, França.

Habitat: adultos são eventualmente encontrados em domicílios, especialmente na Colômbia, mas principalmente em várias espécies de palmeiras. Já foi encontrada em bromélias epífitas (Lent \& Wygodzinsky 1979).

Curiosidades: $R$. robustus é muito similar a $R$. prolixus, entretanto, estudos moleculares têm confirmado o status específicos de ambas as espécies e sugerido que $R$. robustus abriga um complexo de espécies crípticas indistinguíveis através da morfologia (Pavan \& Monteiro 2007). Morfologicamente as ninfas de IV e $V$ estádios de $R$. robustus e $R$. prolixus podem ser diferenciadas através da coloração das tíbias posteriores - nitidamente claras em comparação com os fêmures que apresentam apenas o ápice escuro em $R$. robustus, enquanto que em $R$. prolixus as tíbias são uniformemente escuras (Lent \& Wygodzinsky 1979).

Distribuição: Acre, Amapá, Amazonas, Maranhão, Mato Grosso, Pará, Rondônia, Roraima e Tocantins.

Distribuição fora do Brasil: Bolívia, Colômbia, Equador, Guiana Francesa, Peru e Venezuela. 


\section{Rhodnius stali Lent, Jurberg \& Galvão, 1993}

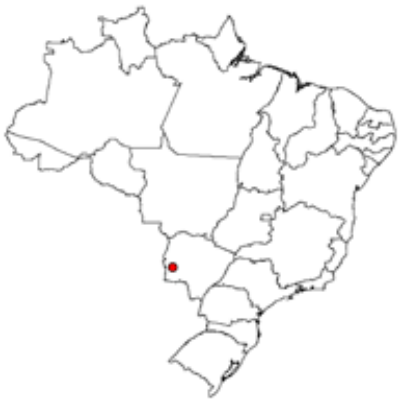

Etimologia: o epíteto específico stali é uma homenagem ao naturalista Carl Stål (18331878).

\section{Características gerais:} comprimento dos machos de 15 a $17 \mathrm{~mm}$, das fêmeas de 16,5 a $19 \mathrm{~mm}$. Coloração geral pardo amarelada com manchas castanho escuro em várias regiões do corpo, causando um aspecto sarapintado. Cabeça igual ou ligeiramente mais longa que o pronoto. Região anteocular cerca de duas vezes e meio mais longa que a pós-ocular $(1: 0,40)$. Olhos em vista lateral ultrapassando o nível da superfície ventral da cabeça, mas não a dorsal. Antenas com o primeiro artículo curto mal atingindo o ápice da cabeça, de coloração pardo amarelada, segundo artículo amarelo na metade basal e preto na apical, terceiro amarelado exceto por uma curta anelação escura na base, quarto amarelado. Proporções entre os artículos antenais $=1: 4,8: 3,6: 2,4$. Rostro com segundo segmento longo terminando ao nível do pescoço. Proporções entre os segmentos do rostro $=1: 4,5: 1$. Pronoto com o lobo anterior ocupando a terça parte do tamanho total, separado do lobo posterior por um sulco pouco evidente. Bordos laterais amarelados. Lobo posterior pardo negro com aspecto levemente sarapintado. Escutelo rugoso, pardo negro. Hemiélitro de coloração palha, quase atingindo a extremidade do abdômen com veias pouco destacadas. Conexivo dorsal amarelo apresentando na metade anterior de cada segmento, uma mancha quadrangular pardo negra, de cuja região central sai uma forte projeção. Pernas amareladas, salpicadas de pardo negro, nas coxas, trocânteres, e principalmente fêmures. Tíbias com duas anelações negras, uma na base do terço mediano e outra no ápice. Para descrição completa veja Lent et al. (1993).

Material tipo: depositado na Coleção Herman Lent do Instituto Oswaldo Cruz, Rio de Janeiro.

Habitat: espécie silvestre, mas encontrada em processo de domiciliação em Alto Beni, Bolívia (Matias et al. 2003).

Curiosidades: essa espécie permaneceu por muitos anos confundida com $R$. pictipes, foi descrita após o exame de material de coleção previamente identificado como $R$. pictipes (Lent et al. 1993).

Distribuição: Mato Grosso do Sul.

Distribuição fora do Brasil: Bolívia.

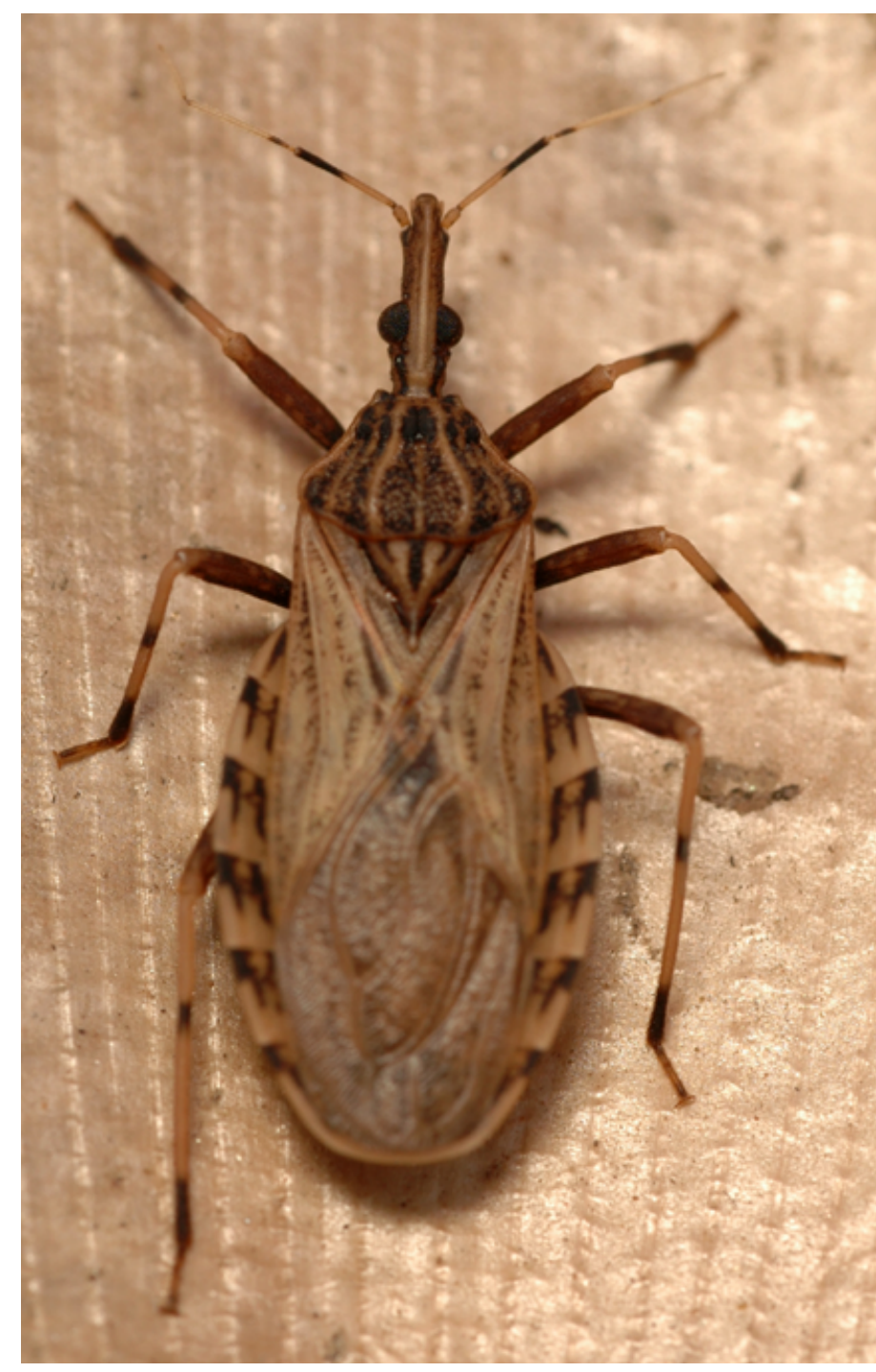
. 


\section{Rhodnius zeledoni Jurberg, Rocha \& Galvão, 1993}

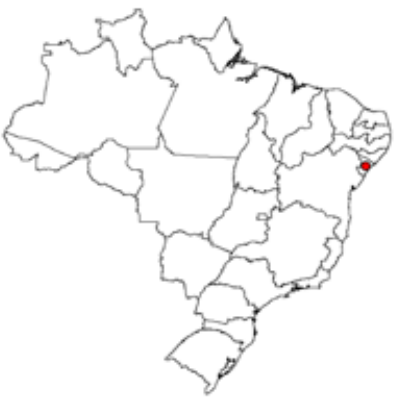

Etimologia: o epíteto específico zeledoni é uma homenagem a Rodrigo Zeledón, parasitologista da Costa Rica.

Características gerais comprimento do macho 13 $\mathrm{mm}$. Coloração geral castanho claro, intercalada com áreas mais escuras em algumas regiões da cabeça, do hemiélitro e do abdômen. Cabeça dorsalmente de cor castanho claro, lateralmen-

te de cor castanho mais escuro. Superfície da cabeça recoberta de pequenos tubérculos com cerdas claras decumbentes com aspecto granuloso. Cabeça mais longa que larga ao nível dos olhos $(1: 0,36)$ e mais longa que o pronoto (1:0,69). Genas ultrapassando levemente o ápice do clípeo. Região anteocular mais longa que a pós-ocular $(1: 0,32)$. Olhos em vista lateral ultrapassando o nível da superfície ventral da cabeça. Relação entre a largura de um olho e a região inter-ocular 1:1,27. Ocelos pequenos. Antena com primeiro segmento castanho escuro, não ultrapassando as genas, demais segmentos ausentes. Rostro com o primeiro segmento muito curto atingindo o nível mediano do tubérculo antenífero, segundo segmento muito longo, com mais de três vezes o tamanho do primeiro, atingindo o nível do anel de constrição entre a cabeça e o pescoço, terceiro segmento muito curto menor que o primeiro atingindo o bordo anterior do sulco estridulatório. Proporções entre os segmentos do rostro $=1: 3,15: 0,84$. Pronoto castanho escuro, com carenas laterais castanho claro alaranjado. Lobo anterior do pronoto pouco diferenciado do lobo posterior, tubérculo discal e lateral inaparentes, como também o ângulo ântero-lateral e o colar. Escutelo castanho alaranjado. Processo do escutelo com ápice arredondado. Hemiélitros de coloração castanho alaranjado com as veias mais claras; base do cório e o clavo castanho escuros; recobrem o abdômen sem ultrapassar o ápice. Pernas amareladas, coxas castanho escuro, os trocânteres castanho claro, fêmures castanho escuro, tíbias e tarsos do primeiro e segundo par castanho escuro, tíbias do terceiro par castanho claro com exceção de anel apical que é escuro. Abdômen ventralmente convexo de cor castanho escuro. Para descrição completa veja Jurberg et al. (2009).

Material tipo: depositado na Coleção Herman Lent do Instituto Oswaldo Cruz, Rio de Janeiro.

Habitat: desconhecido.

Curiosidades: essa espécie é muito similar a Rhodnius domesticus. O único espécime conhecido foi encontrado morto e ressecado no centro da área urbana da cidade de Ribeirópolis, interior de Sergipe. Exame de material adicional é fundamental para confirmar ou invalidar a espécie.

Distribuição: Sergipe. 


\section{Triatoma arthurneivai Lent}

\section{\& Martins, 1940}

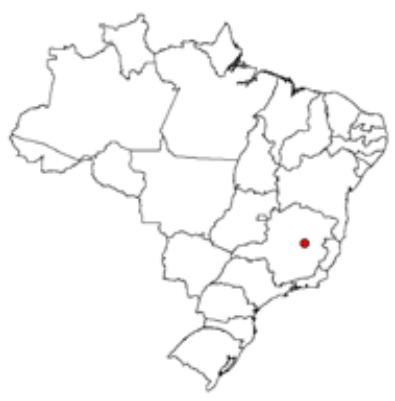

Etimologia: O nome genérico Triatoma foi criado por Laporte (1832-1833) com base em espécimes com antenas quebradas, com apenas três dos quatro artículos (Triatoma = três artículos). Ao analisar novas amostras e perceber seu erro, ele mudou o nome genérico para Conorhinus, mas o nome genérico Triatoma tinha prioridade conforme o Código Internacional de Nomenclatura Zoológica e permaneceu válido. O epíteto específico arthurneivai é uma homenagem a Arthur Neiva (1880-1943), malariologista e entomólogo do Instituto Oswaldo Cruz.

Características gerais: comprimento total dos machos $22 \mathrm{~mm}$, das fêmeas de 19,5 a $21 \mathrm{~mm}$. Coloração geral negra com manchas alaranjadas ou avermelhadas no conexivo. Tegumento quase glabro com cerdas muito pequenas e esparsas. Cabeça negra, delicadamente granulosa, menos de duas vezes mais longa que larga $(1: 0,6)$ e ligeiramente mais curta que o pronoto $(1: 1,1)$. Região anteocular de duas vezes e meia a três vezes mais longa que a pós-ocular (1:0,3-0,4). Genas aguçadas ultrapassando nitidamente o ápice do clípeo. Olhos em vista lateral ultrapassando o nível da superfície ventral e quase alcançando o nível da superfície dorsal da cabeça. Proporção entre a largura de um olho e a região interocular =1:1,0-1,3. Ocelos grandes. Tubérculos anteníferos situados ligeiramente após a metade da região anteocular. Primeiro artículo antenal consideravelmente distante do ápice do clípeo. Proporções entre os artículos antenais $=1: 5,0-6,0: 3,0-3,2: 2,0-2,3$. Rostro castanho avermelhado, mais claro que a cabeça, aparentemente glabro, somente o terceiro segmento com cerdas curtas e muito estreito em vista lateral. Proporções entre os segmentos do rostro = 1:1,8-1,9:0,9-1,0. Pescoço negro com um par de pequenas manchas amarelas lateralmente. Pronoto totalmente negro, só raramente com área humeral alaranjada. Lobo anterior lobo não granuloso com tubérculos dorsais obsoletos ou ausentes e invariavelmente sem tubérculos laterais. Lobo posterior fortemente enrugado. Ângulos ântero-laterais proeminentes, cônicos. Escutelo com processo apical subcilíndrico, tão longo quanto o corpo principal do escutelo, como ápice ligeiramente voltado para cima. Hemiélitro se estendendo até o ápice do sétimo urotergito, em ambos os sexos. Cório negro; clavo negro no terço ou quarto basal. Membrana esfumaçada, castanho claro, mais claro que o cório, veias distintamente mais escura que as células. Pernas uniformemente negras, muito esguias. Tíbias anteriores e medianas dos machos com fossetas esponjosas, ausentes nas fêmeas. Espiráculos situados muito próximos ou adjacentes as suturas conexivais. Conexivo com manchas alaranjadas ou avermelhadas semicirculares na região central de cada segmento e adjacente a margem externa, manchas negras no formato de largas bandas transversais situadas sobre as suturas intersegmentais. Para descrição completa veja Lent \& Wygodzinsky (1979). 
Material tipo: depositado na Coleção Herman Lent do Instituto Oswaldo Cruz, Rio de Janeiro.

Habitat: a espécie foi encontrada em muros de pedras onde pequenos roedores ocorriam. Também foram encontrados em associação com lagartos da espécie Tropidurus torquatus e capturados em armadilhas luminosas.

Curiosidades: espécie de morfologia e coloração muito similar a T. wygodzinskyi, entretanto, o processo do endosoma da genitália masculina, com muitos dentículos, a diferencia de T. wygodzinskyi que apresenta poucos dentículos.

Distribuição: Minas Gerais. 


\section{Triatoma baratai Carcavallo} \& Jurberg, 2000

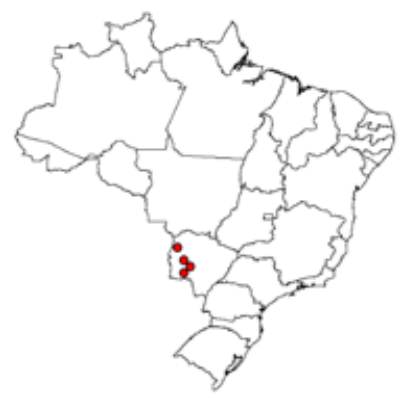

Etimologia: o epíteto específico baratai é uma homenagem a José Maria Soares Barata, pesquisador da área de Entomologia Médica.

Características gerais: Comprimento total do macho $25 \mathrm{~mm}$. Coloração geral negra com áreas alaranjadas no clavo e cório, com exceção das veias e da base interna do cório. Conexivo dorsal totalmente alaranjado, a sutura escura só é visível ventralmente. Cabeça preta, sem rugosidade, mas delicadamente granular, 2,5 vezes mais longa que larga e mais longa que o pronoto (proporção $=1$ : $0,75)$. Região anteocular 5 vezes mais longa que a pós-ocu$\operatorname{lar}($ proporção $=1: 0,20)$. Genas ultrapassando o ápice do clípeo e apicalmente aguçadas. Região interocular quase igual a largura de um olho em vista dorsal. A proporção entre os artículos antenais é 1:4,5:3,9:2. A proporção entre os artículos do rostro é 1:2,5:1. Pronoto inteiramente preto e brilhante. $\mathrm{O}$ lobo anterior tem os tubérculos discais apenas aparentes e os tubérculos laterais ausentes. Escutelo, preto e brilhante. Pernas inteiramente pretas, fêmures anteriores com tubérculos rudimentares subapicais. Fêmures medianos com tubérculos no quarto apical. Tíbias anteriores e medianas com fosseta esponjosa muito pequenas e pouco visíveis. Abdômen em vista ventral preto, muito convexo. Para descrição completa veja Carcavallo \& Jurberg (2000).

Material tipo: depositado na coleção Rodolfo Carcavallo do Instituto Oswaldo Cruz, Rio de Janeiro e na Faculdade de Saúde Pública, Universidade de São Paulo.

Habitat: espécie silvestre capturada pela primeira vez em armadilha de Shannon próxima a entrada de uma gruta.

Distribuição: Mato Grosso do Sul. 


\section{Triatoma brasiliensis} Neiva, 1911

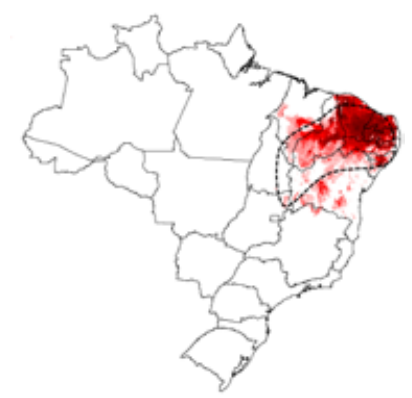

Etimologia: o epíteto específico brasiliensis é uma referência à distribuição exclusivamente brasileira da espécie.

Sinônimos: Conorhinus brasiliensis Patton \& Cragg, 1913; Triatoma brasiliensis macromelasoma Galvão, 1956.

Características gerais: comprimento total dos machos de 22 a $25 \mathrm{~mm}$, das fêmeas de 23 a $25,5 \mathrm{~mm}$. Coloração geral de castanho escuro a negro com manchas amareladas no pescoço, pronoto, pernas, hemiélitro e conexivo. Tegumento com cerdas negras ou amareladas esparsas. Cabeça castanho escuro ou negra, rugosa dorsal e lateralmente e duas vezes mais longa que larga ao nível dos olhos $(1: 0,5-0,55)$ e distintamente mais longa que o pronoto $(1: 0,85-0,95)$. Região anteocular quatro vezes mais longa que a pós-ocular $(1: 0,25)$. Olhos em vista lateral não alcançando a superfície ventral e bem distantes da superfície dorsal da cabeça. Proporção entre a largura de um olho e a região interocular $=1: 2, .0-2,25$. Tubérculos anteníferos inseridos na metade, ou ligeiramente antes da metade da região anteocular. Primeiro artículo antenal atingindo o nível do ápice do clípeo. Proporções entre os artículos antenais = 1:3,6-4,2:2,4$2,7: 1,9-2,2$. Rostro grosso, tão escuro quanto a cabeça. Proporções entre os segmentos do rostro = 1:1.7-1.9:0.9-1.05. Pescoço escuro com um par de manchas claras laterais. Pronoto castanho escuro a negro com manchas amareladas no colar, processos laterais, tubérculos discais do lobo anterior, totalidade das carenas submedianas e área adjacente as carenas. Lobo anterior com tubérculos discais muito pequenos, difíceis de perceber; tubérculos laterias ausentes. Ângulos humerais arredondados. Escutelo

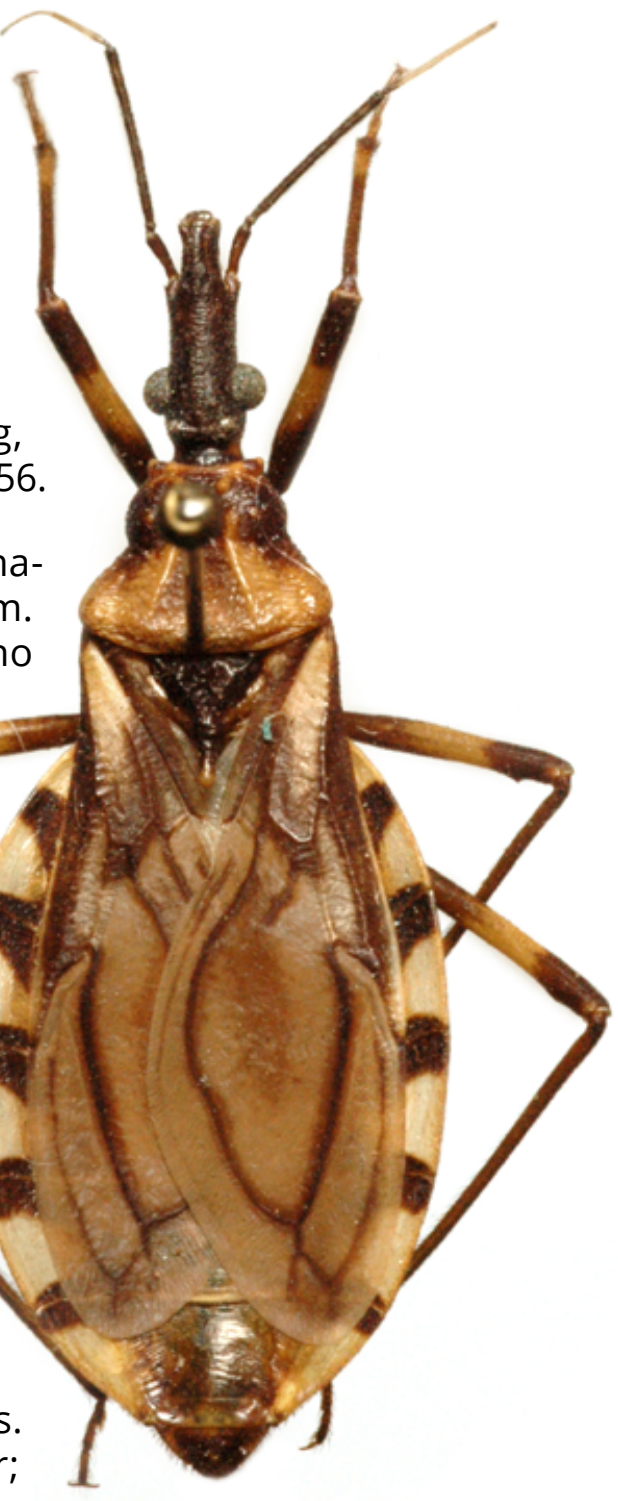
castanho escuro, processo apical tão longo quanto o corpo principal do escutelo e com a ponta amarelada em alguns espécimes. Hemiélitro com cório amarelo claro com áreas escuras de extensão variável. Clavo inteiramente negro. Membrana esfumaçada, de amarelo claro a castanho claro. Veias da membrana negras. Pernas escuras com anelação clara nos fêmures. Para descrição completa veja Lent \& Wygodzinsky (1979).

Material tipo: depositado na Coleção Herman Lent do Instituto Oswaldo Cruz, Rio de Janeiro.

Habitat: frequentemente domiciliada é atualmente a mais importante transmissora da doença ao ser humano no nordeste do Brasil. No ambiente silvestre podem ser encontradas principalmente entre e sob pedras associadas a roedores.

Curiosidades: A variabilidade cromática do complexo T. brasiliensis levou, no passado, à descrição de duas subespécies melânicas: Triatoma brasiliensis melanica Neiva \& Lent,1941 e Triatoma brasiliensis macromelasoma Galvão, 1956. Lent \& Wygodzsinky (1979) invalidaram as subespécies e sinonimizaram ambas com T. brasiliensis, estudos posteriores, entretanto, elevaram T. brasiliensis melanica ao status de espécie como Triatoma melanica (Costa et al. 2006). Posteriormente, uma nova espécie (Triatoma juazeirensis, Costa \& Felix 2007) foi descrita e incluída no complexo T. brasiliensis.

Distribuição: Alagoas, Bahia, Ceará, Goiás, Maranhão, Paraíba, Pernambuco, Piauí, Sergipe, Tocantins e Rio Grande do Norte 


\section{Triatoma carcavalloi Jurberg, Rocha \& Lent, 1998}

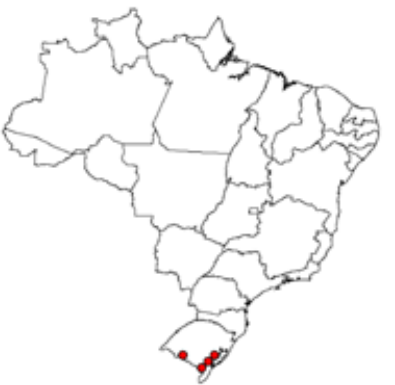

fêmeas de 20 a 22 mm. Coloração geral negra com grandes manchas alaranjadas ou avermelhadas no lobo posterior do pronoto, cório e conexivo. Pilosidade curta. Cabeça negra, moderadamente rugosa, 3 vezes mais longa que larga e mais longa que o pronoto (proporção = 1:0,8). Genas longas quase atingindo o ápice do clípeo e apicalmente arredondadas. Região interocular com duas vezes a largura de um olho em vista dorsal. A proporção entre os artículos antenais é $1: 4,5: 2,2: 2$. A proporção entre os artículos do rostro é 1:2:1,2. Pronoto com o colar negro e ângulos ântero-laterais acentuados e cônicos, ligeiramente divergentes. O lobo anterior tem os tubérculos discais bem desenvolvidos, tubérculos laterais ausentes. Lobo posterior laranjado ou avermelhado, ângulos humerais arredondados. Escutelo, preto. Pernas uniformemente pretas, exceto por algumas áreas tarsais castanhas. Fêmures anteriores e medianos com um par de tubérculos rudimentares subapicais. Tíbias das fêmeas sem fossetas esponjosas. Abdômen largo, com parte dos urotergitos expostos, ventralmente negro, convexo, polido e brilhante. Para descrição completa veja Jurberg et al. (1998).

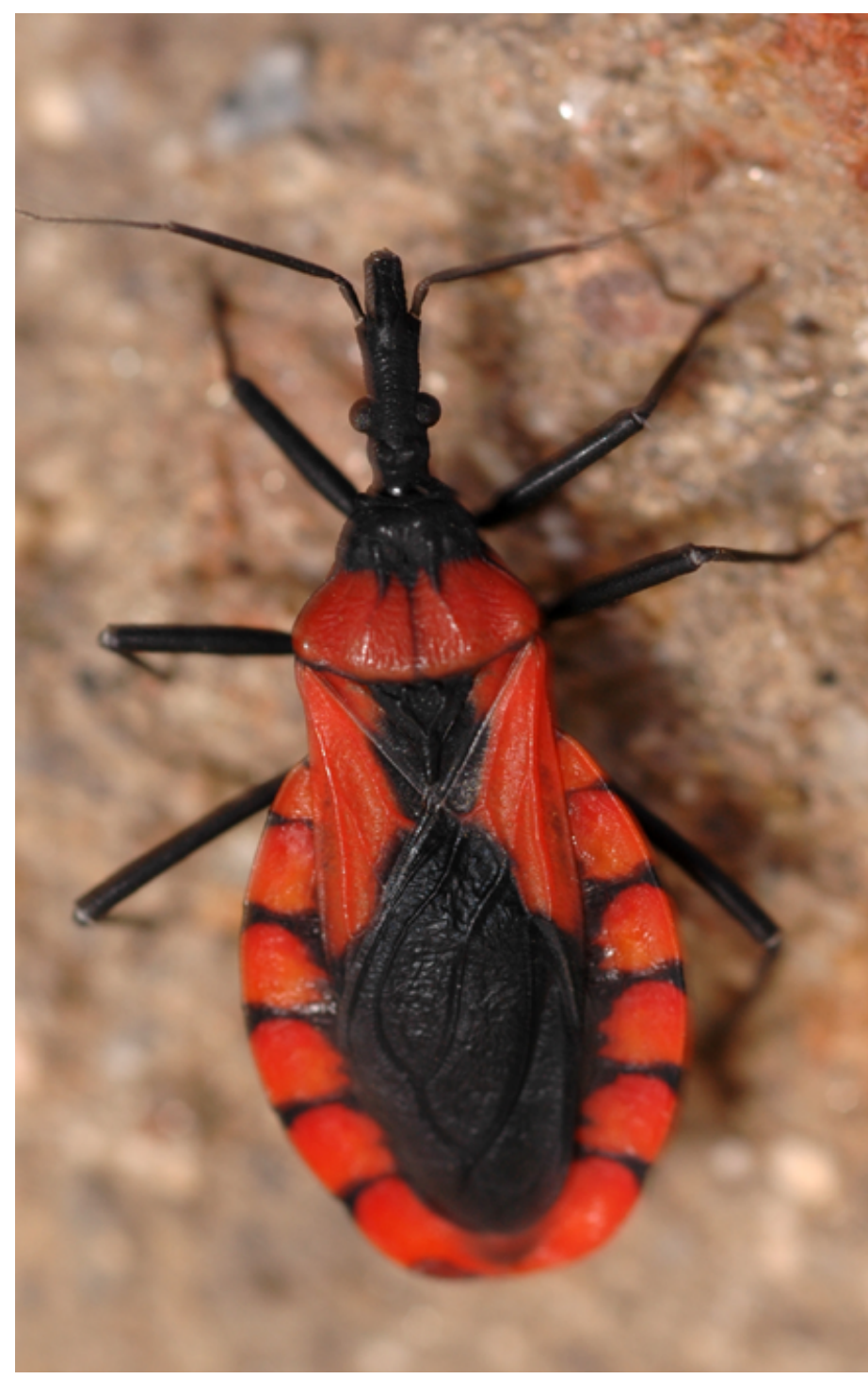

Material tipo: depositado na coleção Rodolfo Carcavallo do Instituto Oswaldo Cruz, Rio de Janeiro.

Habitat: os espécimes que permitiram a descrição da espécie foram encontrados mortos em domicílios, posteriormente Ruas Neto \& Corseiul (2002) a encontraram sob rochas.

Distribuição: Rio Grande do Sul. 


\section{Triatoma circummaculata (Stål, 1859)}

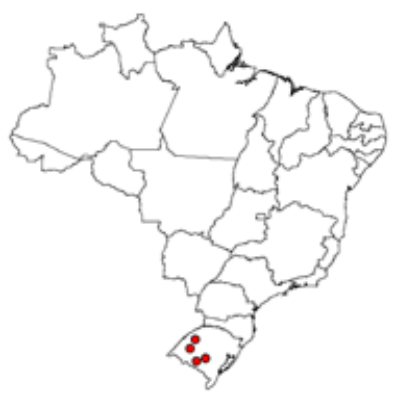

Etimologia: o epíteto específico circummaculata vem do latim "circum" que significa, ao redor e "maculata", "maculatus" que significa manchado, uma referência as máculas ao redor (no conexivo) do inseto.

Sinônimos: Conorhinus circummaculatus Stål, 1859; Neotriatoma circummaculata Pinto, 1931; Triatoma (Neotriatoma) circummaculata Lima, 1940

Características gerais: comprimento total dos machos de 15 a 16 $\mathrm{mm}$, das fêmeas de 15 a $17 \mathrm{~mm}$. Coloração geral castanho escuro ou negro, com manchas vermelhas no pronoto, cório e conexivo. Pilosidade curta. Cabeça delicadamente rugosa e granulosa com cerdas curtas, duas vezes mais longa que larga ao nível dos olhos $(1: 0,4-0,5)$ e distintamente mais longa que o pronoto $(1: 0,7-$ $0,8)$. Região anteocular duas vezes e meio mais longa que a pós-ocular (1:0,35-0,4). Genas ultrapassando ligeiramente o ápice do clípeo. Olhos em vista lateral ultrapassando a superfície ventral, mas bem distantes da superfície dorsal da cabeça. Proporção entre a largura de um olho e a região interocular $=1: 1,35-1,75$. Tubérculos anteníferos inseridos ligeiramente após a metade da região anteocular. Primeiro artículo antenal curto não ultrapassando a metade das genas. Proporções entre os artículos antenais $=1: 3,3-4,0: 3,0-4,2: 2,0-2,7$. Rostro castanho claro, contrastando com a cabeça negra. Primeiro segmento muito curto, segundo segmento se estendendo até o bordo anterior dos olhos ou ligeiramente além, terceiro tão longo quanto o segundo. Cerdas do rostro curtas e esparsas com exceção do ápice do terceiro segmento. Proporções entre os segmentos do rostro = 1:2:2. Pescoço castanho escuro com um par de manchas laterais avermelhadas. Pronoto com lobo anterior variando de castanho escuro a negro, lobo posterior como o lobo

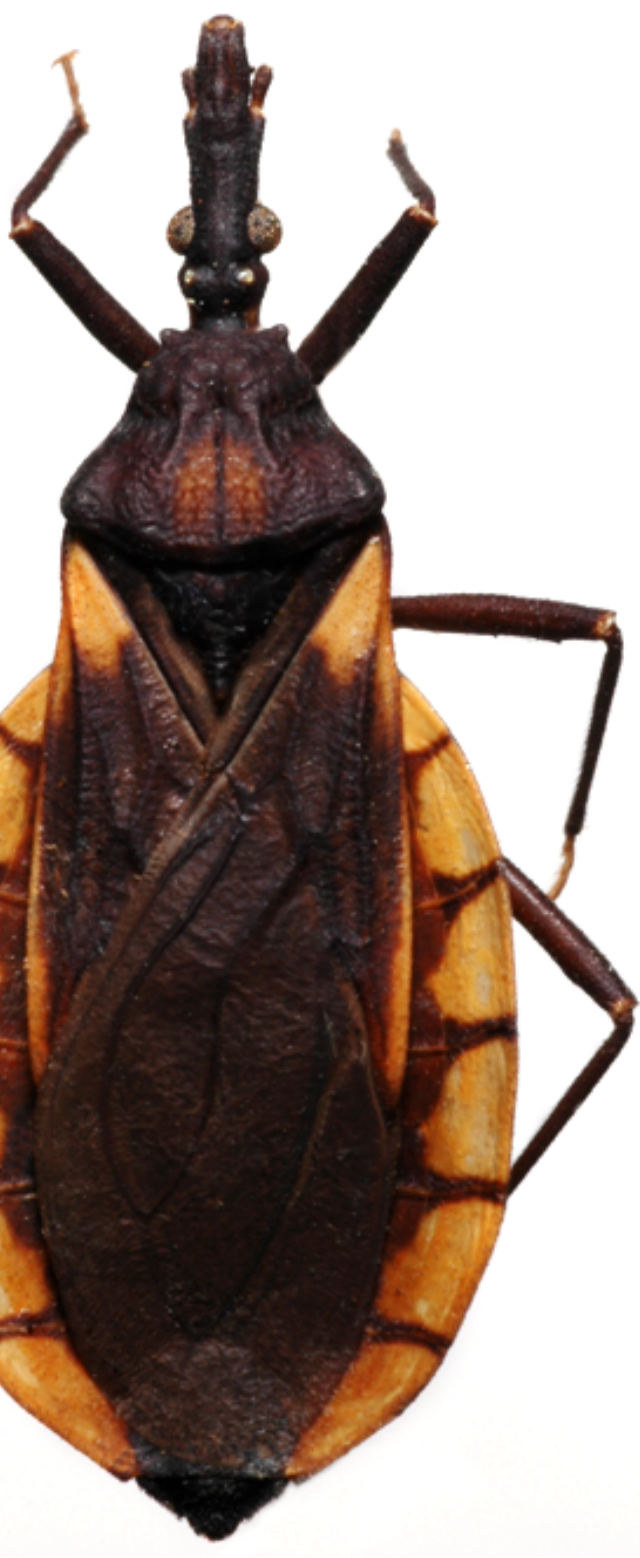
anterior ou variando de parcialmente a totalmente vermelho. Tubérculos discais e laterais ausentes. Ângulos ântero-laterais curtos, sub-cônicos. Escutelo com processo apical da metade do comprimento do corpo principal e raramente com ápice claro. Hemiélitro atingindo ou se aproximando do ápice do sétimo urotergito. Cório castanho escuro ou enegrecido, vermelho na base e com pequenas manchas avermelhadas subapicais. Membrana castanho escuro, enfumaçada. Pernas uniformemente negras. Fêmures anteriores e medianos com um par de pequenos dentículos subapicais. Tíbias anteriores e medianas dos machos com fossetas esponjosas, ausentes nas fêmeas. Abdômen castanho escuro. Conexivo vermelho brilhante com faixas negras transversais estreitas localizadas sobre as suturas inter-segmentares. Para descrição completa veja Lent \& Wygodzisnky (1979). 
Material tipo: depositado no Zoologisches Museum, Berlim, Alemanha.

Habitat: espécie silvestre encontrada sob rochas e em fendas de muros de pedras, frequentemente junto com Triatoma rubrovaria e associada a baratas das quais se alimenta sugando a hemolinfa (Almeida et al. 2002).

Curiosidades: espécie que apresenta grande variabilidade cromática no lobo posterior do pronoto variando de completamente negro a completamente vermelho (Di Primio, 1962). Espécie cromaticamente muito similar a Triatoma carcavalloi.

Distribuição: Rio Grande do Sul.

Distribuição fora do Brasil: Uruguai. Segundo Lent \& Wygodzinsky (1979) a ocorrência dessa espécie na Argentina, especialmente em Córdoba e San Luis é duvidosa. 


\section{Triatoma costalimai} Verano \& Galvão, 1958

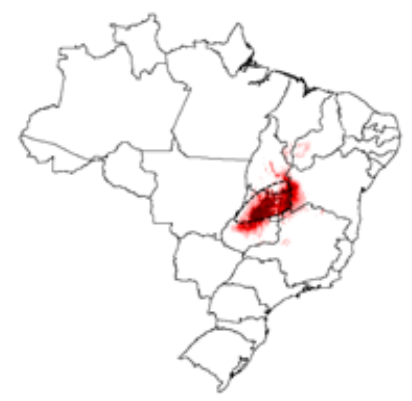

Etimologia: o epíteto específico costalimai é uma homenagem a Ângelo Moreira da Costa Lima (1887-1964), entomólogo brasileiro do Instituto Oswaldo Cruz.

Características gerais: comprimento total dos machos 26 mm, das fêmeas de 25,5 a $26,5 \mathrm{~mm}$. Coloração geral castanho escuro ou negro, com manchas avermelhadas no pescoço, cório e conexivo. Pilosidade curta e esparsa. Cabeça negra duas vezes mais longa que larga ao nível dos olhos $(1: 0,45)$ e distintamente mais longa que o pronoto $(1: 0,75)$. Região anteocular quatro vezes mais longa que a pós-ocular (1:0,25). Genas pontudas projetando-se além do nível do ápice do clípeo. Jugas apicalmente angulosas. Olhos pequenos, em vista lateral aproximando-se, mas não ultrapassando o nível da superfície ventral e distante da superfície dorsal da cabeça. Proporção entre a largura de um olho e a região interocular $=1: 1,6-2,0$. Tubérculos anteníferos inseridos no meio da região anteocular. Primeiro artículo antenal muito curto não alcançando o nível do ápice do clípeo. Proporções entre os artículos antenais $=1: 5,6-6,4: 4,4: 3,2$. Rostro robusto, tão escuro, ou um pouco mais claro que a cabeça. Proporções entre os segmentos do rostro = 1:2.6-2.7:1. Pescoço escuro com um par de manchas laterais avermelhadas. Pronoto totalmente castanho escuro ou preto. Lobo anterior fracamente granuloso com 1+1 tubérculos discais pouco perceptíveis, tubérculos laterais ausentes. Lobo posterior muito rugoso. Ângulos humerais arredondados. Escutelo rugoso. Processo apical quase tão longo quanto o corpo principal. Hemiélitro atingindo o ápice do sétimo urotergito em ambos os sexos. Cório e clavo negros, ápice do cório com margem avermelhada nítidas manchas avermelhadas. Membrana cinza escuro com áreas fracamente tingidas de avermelhado. Pernas uniformemente negras, longas. Fêmures anteriores e medianos com um par de pequenos dentículos subapicais. Tíbias anteriores e medianas dos machos com fossetas esponjosas, ausentes nas fêmeas. Abdômen castanho escuro. Conexivo castanho escuro, cada segmento com uma mancha vermelho-alaranjado de tamanho variável situada ao longo do bordo externo. Para descrição completa veja Lent \& Wygodzisnky (1979).

Material tipo: depositado na Coleção Herman Lent do Instituto Oswaldo Cruz, Rio de Janeiro.

Habitat: entre rochas calcárias próximas a ninhos de Kerodon rupestris, D. albiventris, $T$. apereoides, O. eliurus e C. callosus. Ninfas e adultos já foram encontrados no peridomicílio.

Distribuição: Bahia, Goiás, Minas Gerais, Mato Grosso e Tocantins 


\section{Triatoma deaneorum Galvão, Souza \& Lima, 1967}

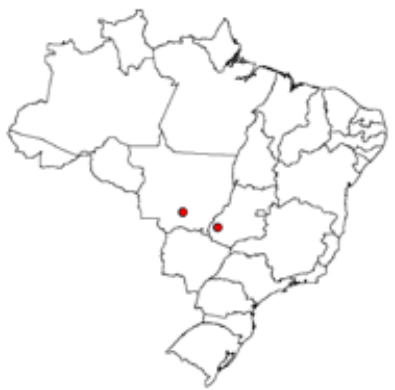

Etimologia: o epíteto específico deaneorum é uma homenagem ao casal Leônidas (19141993) e Maria Deane (1916-1995), parasitologistas brasileiros.

Características gerais: comprimento total dos machos $25 \mathrm{~mm}$, das fêmeas $27 \mathrm{~mm}$. Coloração geral castanho escuro. Pilosidade curta e esparsa.

Cabeça castanha escura, menos que duas vezes mais longa que larga ao nível dos olhos $(1: 0,55)$ e distintamente mais longa que o pronoto $(1: 0,9)$. Região anteocular quatro vezes mais longa que a pós-ocular (1:0,25). Genas projetando-se além do nível do ápice do clípeo. Jugas apicalmente angulosas. Olhos em vista lateral aproximando-se, mas não ultrapassando o nível da superfície ventral e distante da superfície dorsal da cabeça. Proporção entre a largura de um olho e a região interocular = 1:1,3. Tubérculos anteníferos inseridos no meio da região anteocular. Primeiro artículo antenal muito curto não alcançando o nível do ápice do clípeo. Proporções entre os artículos antenais = 1:4,6:?:?. Rostro castanho amarelado, mais claro que a cabeça. Proporções entre os segmentos do rostro $=1: 2,25-2,5: 1$. Pescoço escuro com um par de manchas laterais amareladas. Pronoto negro. Lobo anterior não granuloso com tubérculos discais e laterais discretos, porém, perceptíveis. Lobo posterior nitidamente rugoso. Ângulos humerais arredondados. Escutelo uniformemente negro. Hemiélitro atingindo o ápice do sétimo urotergito em ambos os sexos. Clavo amarelado, mais escuro ao longo da margem externa, cório castanho-amarelado claro. Membrana castanho-amarelado claro com veias mais escuras. Pernas castanho escuras, trocânteres e base dos fêmures amareladas. Fêmures anteriores e medianos com um par de pequenos dentículos subapicais. Tíbias anteriores e medianas com fossetas esponjosas, ausentes nas fêmeas. Abdômen castanho escuro. Conexivo com grande mancha amarela em cada segmento. Para descrição completa veja Lent \& Wygodzisnky (1979).

Material tipo: depositado na Coleção do Instituto Butantan, São Paulo.

Habitat: Os únicos espécimes conhecidos foram encontrados no interior de domicílios.

Distribuição: Mato Grosso e Goiás. 


\section{Triatoma delpontei Romana \& Abalos, 1947}

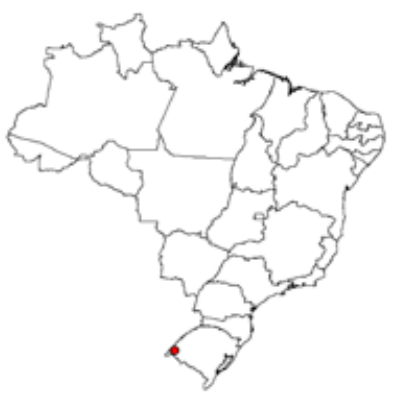

Etimologia: o epíteto específico delpontei é homenagem a Eduardo Del Ponte (1887-1969), entomólogo Argentino.

Características gerais: comprimento total dos machos de 24 a $26 \mathrm{~mm}$, das fêmeas de 25 a $27 \mathrm{~mm}$. Robusto e fortemente esclerotizado. Coloração castanho escuro avermelhado ou negra, fosco ou ligeiramente polido, com marcações amareladas no pescoço e conexivo. Pilosidade dourada, distinta, mas não tão abundante quanto em T. platensis. Cabeça castanho avermelhado escuro, pilosa e esparsamente granulosa; quase duas vezes mais longa que larga ao nível dos olhos (1:0,6) e tão longa quanto o pronoto. Região anteocular três a quatro vezes mais longa que a pós-ocular. Genas aguçadas projetando-se consideravelmente além do nível do ápice do clípeo. Jugas angulosas apicalmente. Olhos em vista lateral quase atingindo o nível da superfície ventral e distantes da superfície dorsal da cabeça. Proporção entre a largura de um olho e a região interocular = 1:2.1-2.2. Tubérculos anteníferos inseridos no meio da região anteocular. Primeiro artículo antenal não alcançando o nível do ápice do clípeo. Proporções entre os artículos antenais $=1: 3 \cdot 3-3 \cdot 5: 2 \cdot 0-2 \cdot 3: 1.5$. Rostro tão escuro quanto a cabeça, cerdas primeiro segmento do rostro muito curtas, longas e densas no terceiro. Primeiro segmento atingindo o nível do ápice da juga, segundo artículo atingindo o nível do bordo posterior dos olhos. Proporções entre os segmentos do rostro = 1:2:1. Pronoto da mesma coloração do corpo. Lobo anterior ligeiramente granulosos 1+1 tubérculos discais pontudos, 1+1 pequenos tubérculos laterais e 1+1 tubérculos póstero-sublaterais obsoletos. Lobo posterior irregularmente enrugados. Escutelo fortemente rugoso. Hemiélitro atingindo o ápice do sétimo urotergito nos dois sexos. Pernas castanho escuras ou negras. Fêmures anteriores e medianos com um par de pequenos dentículos subapicais. Fossetas esponjosas presentes nas tíbias anteriores e medianas dos machos, ausente nas fêmeas. Cerdas das pernas numerosas e visíveis a olho nu. Abdômen ventral com numerosas cerdas. Para descrição completa veja Lent \& Wygodzisnky (1979).

Material tipo: depositado no Instituto Miguel Lillo, Tucuman, Argentina.

Habitat: espécie basicamente ornitofílica encontrada com maior frequência nos ninhos do papagaio Myiopsitta monacha cotorra (Vieillot), uma vez que os ninhos tenham sido abandonados passam a se alimentar de pequenos roedores ou didelfídeos que se apossam dos ninhos (Salvatella et al. 1993).

Distribuição: Rio Grande do Sul.

Distribuição fora do Brasil: Argentina, Bolívia, Paraguai e Uruguai 


\section{Triatoma guazu Lent \& Wygodzinsky, 1979}

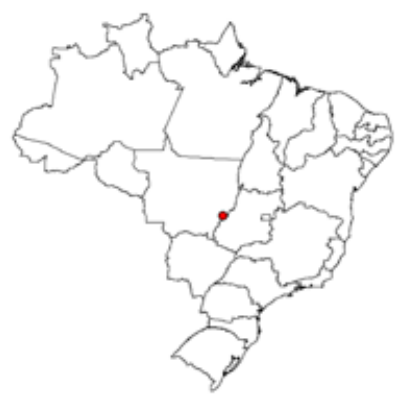

Etimologia: o epíteto específico guazu é derivado do guarani e significa grande, uma referência ao fato dessa ser uma das maiores espécies do gênero.

Características gerais: comprimento total dos machos $26 \mathrm{~mm}$, das fêmeas de 29 a $30 \mathrm{~mm}$. Coloração geral negra, com manchas amareladas no pescoço, cório e conexivo. Pilosidade curta e esparsa. Cabeça negra, rugosa; duas a três vezes mais longa que larga ao nível dos olhos (1:0,4-0,5) e mais longa que o pronoto $(1: 0,9)$. Região anteocular quatro vezes mais longa que a pós-ocular (1:0,25). Genas projetando-se além do nível do ápice do clípeo. Jugas arredondadas apicalmente. Olhos em vista lateral ultrapassando levemente o nível da superfície ventral e ultrapassando nitidamente a superfície dorsal da cabeça. Proporção entre a largura de um olho e a região interocular $=1: 1,25$. Tubérculos anteníferos inseridos no meio da região anteocular. Primeiro artículo antenal não alcançando o nível do ápice do clípeo. Proporções entre os artículos antenais = 1:4,6:3,5:2,3. Rostro escuro, castanho avermelhado. Proporções entre os segmentos do rostro $=1: 2,5: 1,1$. Pescoço negro com um par de manchas laterais amareladas. Pronoto totalmente negro. Lobo anterior pouco granuloso sem tubérculos discais ou laterais. Lobo posterior rugoso. Húmeros salientes e arredondados. Ângulos ântero-laterais pequenos, projetados lateralmente. Escutelo negro, fortemente rugoso. Hemiélitro atingindo o ápice do oitavo urotergito nos dois sexos e de colorido geral pálido; clavo preto enfumaçado na base e com a metade final amarelo-claro. Membrana castanho-amarelado claro com veias mais escuras. Pernas castanho escuras ou negras, trocânteres e base dos fêmures mais amareladas. Fêmures anteriores e medianos com um par de pequenos dentículos subapicais. Tíbias anteriores e medianas com fossetas esponjosas, ausentes nas fêmeas. Abdômen castanho escuro a negro. Conexivo com grande mancha amarelada em cada segmento. Para descrição completa veja Lent \& Wygodzisnky (1979) e Lent et al. (1996).

Material tipo: depositado no American Museum of Natural History, Nova Iorque, EUA e na Coleção Herman Lent do Instituto Oswaldo Cruz, Rio de Janeiro.

Habitat: somente espécimes adultos foram encontrados em domicílios

Distribuição: Mato Grosso

Distribuição fora do Brasil: Paraguai 


\section{Triatoma infestans} (Klug, 1834)

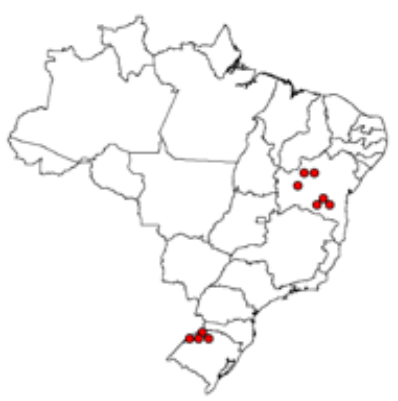

Etimologia: o epíteto específico infestans vem do latim "infesto, infestare, infestavi, infestatus" que significa perturbar, infestar, prejudicar.

Sinônimos: Reduvius infestans Klug in Meyen, 1834; Conorhinus infestans Berg, 1879; Conorhinus renggeri Herrich-Schaeffer, 1848; Conorhinus sex-tuberculatus Spinola in Gay, 1852; Conorhinus paulseni Philippi, 1860; Conorhinus gracilipes Philippi, 1860; Conorhinus octotuberculatus Philippi, 1860; Conorhinus gigas Burmeister, 1861; Conorhinus nigrovarius Blanchard, 1890; Triatoma infestans erythrophthalmus Noé \& Silva, 1949; Triatoma infestans melanosoma, Martínez, Olmedo \& Carcavallo, 1987; Triatoma oswaldoi Niño, 1936; Eutriatoma oswaldoi Niño, 1936; Triatoma sordelli Dios \& Zuccarini, 1936; Triatoma mazzae Jörg, 1937; Triatoma melanosoma Lent et al. 1994.

Características gerais: comprimento total dos machos de 21 a 26 mm, das fêmeas de 26 a 29 mm. Coloração geral negra ou castanho escuro, com manchas amareladas nas pernas, cório e conexivo. Pilosidade curta e esparsa. Cabeça negra delicadamente rugosa; duas vezes mais longa que larga ao nível dos olhos $(1: 0,5-0,55)$ e tão longa quanto o pronoto $(1: 0,9)$. Região anteocular três vezes mais longa que a pós-ocular (1:0,3). Genas arredondadas distalmente, ultrapassando ligeiramente o nível do ápice do clípeo. Olhos em vista lateral próximos ou atingindo o nível da superfície ventral, mas não alcançando a superfície dorsal da cabeça. Proporção entre a largura de um olho e a região interocular = 1:1,5-1,8. Tubérculos anteníferos inseridos no meio da região anteocular. Primeiro artículo antenal não alcançando o nível do ápice do clípeo. Proporções entre os artículos antenais $=1: 3 \cdot 5-3 \cdot 7: 2 \cdot 9-3 \cdot 3: 2 \cdot 0-2 \cdot 3$. Rostro tão escuro ou mais claro que a cabeça. Proporções entre os segmentos do rostro = 1:1,7-2,0:1,0. Pescoço negro com um par de manchas laterais amareladas. Pronoto totalmente negro. Lobo anterior com 1+1 tubérculos discais e pequenos tubérculos laterais. Lobo posterior rugoso. Húmeros salientes e elevados. Ângulos ântero-laterais pequenos. Escutelo negro, fortemente rugoso. Hemiélitro não atingindo o ápice do sétimo urotergito nos dois sexos e de colorido geral escuro. Clavo negro com manchas amarelo pálido na base. Membrana com veias escuras. Pernas totalmente negras ou com os trocânteres e base dos fêmures amarelados. Fêmures anteriores e medianos com um par de pequenos dentículos subapicais. Tíbias anteriores e medianas com fossetas esponjosas presentes apenas nos machos. Conexivo preto, cada segmento com grande mancha amarela afastada da sutura anterior, mas estreitamente próxima da fronteira do segmento posterior. Para descrição completa veja Lent \& Wygodzisnky (1979).

Material tipo: de infestans depositado no Zoologisches Museum, Berlim, Alemanha; de paulseni, gracilipes e octotuberculatus, no Museu de Historia Natural de Santiago, 
Chile; de oswaldoi e melanosoma na Coleção Herman Lent do Instituto Oswaldo Cruz, Rio de Janeiro; de sordelli, no Instituto Bacteriológico, Buenos Aires, Argentina; de mazzae, na Mision de Estudios de Patología Regional, Buenos Aires, Argentina.

Habitat: espécie quase exclusivamente domiciliar, populações silvestres arborícolas e rupestres têm sido encontradas na Bolívia (Cortez et al. 2007).

Distribuição: atual, apenas em raros focos residuais no Rio Grande do Sul e Bahia. Antes do sucesso dos programas de controle do Ministério da Saúde: Alagoas, Bahia, Goiás, Maranhão, Mato Grosso, Mato Grosso do Sul, Minas Gerais, Paraná, Paraíba, Pernambuco, Piauí, Rio de Janeiro, Rio Grande do Sul, Santa Catarina, Sergipe, São Paulo e Tocantins.

Distribuição fora do Brasil: Argentina, Bolívia, Chile, Paraguai, Peru, Uruguai. 


\section{Triatoma jatai Gonçalves et al., 2013}

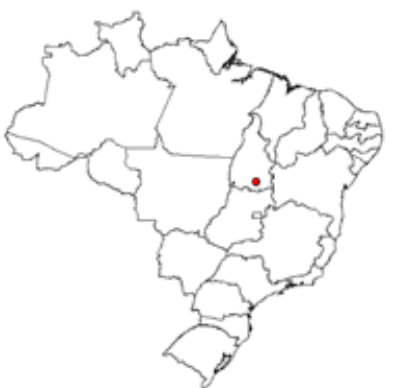

Etimologia: o epíteto específico jatai é uma referência ao local de coleta Fazenda Jatai.

Características gerais: comprimento total dos machos $18,6 \mathrm{~mm}$, das fêmeas 20,15 mm. Cabeça castanha, alongada, levemente rugosa; quatro vezes mais longa que larga ao nível

dos olhos(1:0,23), e mais longa que o pronoto $(1: 0,23)$ ou tão longa quanto o pronoto e o escutelo juntos, coberta por cerdas curtas. Região anteocular quatro vezes mais longa que a pós-ocular $(1: 0,22)$. Genas acentuadas, ultrapassando o nível do ápice do clípeo. Olhos em vista lateral não atingindo o nível da superfície ventral, e distantes da superfície dorsal da cabeça. Proporção entre a largura de um olho e a região interocular $=1: 1,05$. Tubérculos anteníferos inseridos no meio da região anteocular. Primeiro artículo antenal atingindo a metade do clípeo. Proporções entre os artículos antenais = 1:4.5:2.7:2.4. Rostro com a mesma coloração da cabeça. Proporções entre os segmentos do rostro $=1: 3: 1$. Pronoto castanho, rugoso com 1+1 tubérculos discais e laterais ausentes. Ângulos humerais arredondados podendo apresentar 1+1 mancha clara. Escutelo castanho, rugoso com uma depressão central em forma de $V$, com processo apical cilíndrico tão longo quanto o corpo do escutelo. Hemiélitro atingindo ou quase atingindo o ápice do sétimo urotergito. Cório e clavo castanhos, com 2+2 manchas ocre na região basal e apical. Membrana cinza, com veias negras. Pernas castanhas. Conexivo predominantemente castanho com manchas claras basais triangulares de largura variável. Para descrição completa veja Gonçalves et al. (2013).

Material tipo: depositado na Coleção Herman Lent do Instituto Oswaldo Cruz, Rio de Janeiro.

Distribuição: Tocantins. 


\section{Triatoma juazeirensis} Costa \& Felix, 2007

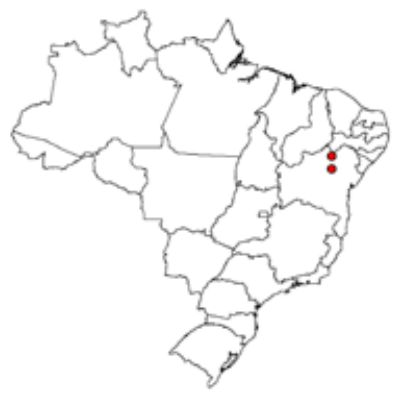

Etimologia: o epíteto específico juazeirensis é uma referência ao município de Juazeiro (Bahia) local de captura do material tipo.

Características gerais: comprimento total dos machos de 20 a $24 \mathrm{~mm}$, das fêmeas de 23 a 25,5 mm. Coloração geral negra. Cabeça negra, rugosa nas regiões dorsal e lateral; duas vezes mais longa que larga ao nível dos olhos $(1: 0,45-0,50)$ e distintamente mais longa que o pronoto $(1: 0,65-0,85)$. Região anteocular quatro vezes mais longa que a pós-ocular (1:0,25). Genas ultrapassando o nível do ápice do clípeo. Olhos em vista lateral não atingindo o nível da superfície ventral, e distantes da superfície dorsal da cabeça. Proporção entre a largura de um olho e a região interocular = 1:1,75-2,0. Tubérculos anteníferos inseridos no meio ou ligeiramente antes do meio da região anteocular. Primeiro artículo antenal atingindo o nível do ápice do clípeo. Proporções entre os artículos antenais = 1:3,4-4,6:2,3-3,0:1,92,6 . Rostro tão escuro quanto a cabeça. Proporções entre os segmentos do rostro $=1: 1 \cdot 6-2 \cdot 2: 0 \cdot 8-1 \cdot 2$. Pescoço negro com um par de manchas laterais claras. Pronoto com lobo anterior negro, tubérculos discais pequenos e laterais ausentes. Lobo posterior rugoso. Escutelo negro com processo apical tão longo quanto o corpo do escutelo. Hemiélitro de comprimento variável atingindo desde a base até o ápice do sétimo urotergito. Cório amarelo-claro, com áreas escuras de extensão variável. Clavo totalmente negro. Membrana castanha amarelada, com veias negras.

Pernas negras com áreas claras nos trocânteres. Fêmures totalmente negros. Tíbias com porção subapical ligeiramente amarelada, fossetas esponjosas presentes apenas nas tíbias anteriores e medianas dos machos. Conexivo com manchas amareladas, retangulares ou subtriangulares; mancha negra localizada sobre as suturas inter-segmentares e de tamanho similar às manchas amareladas. Para descrição completa veja Costa \& Felix (2007).

Material tipo: depositado na Coleção Entomológica, Instituto Oswaldo Cruz, Rio de Janeiro; no Museu de Zoologia da Universidade de São Paulo, São Paulo e no Museu de História Natural da Flórida (Universidade da Flórida), Gainesville, EUA.

Habitat: pode ser encontrada no ambiente silvestre, entre rochas, em ecótopos semelhantes àqueles infestadas por $T$. brasiliensis e principalmente no peridomicílio.

Distribuição: Bahia 


\section{Triatoma jurbergi Carcavallo,} Galvão \& Lent, 1998

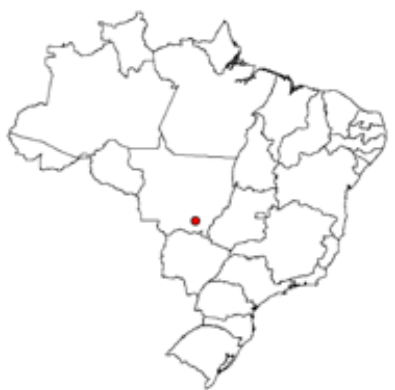

Etimologia: o epíteto específico jurbergi é uma homenagem a José Jurberg, entomólogo do Instituto Oswaldo Cruz, especialista em triatomíneos.

Características gerais: comprimento total dos machos de 25 a $26 \mathrm{~mm}$, das fê-

meas de 27 a $28 \mathrm{~mm}$. Coloração geral castanho avermelhado. Cabeça castanho avermelhado, suavemente granulosa; quase três vezes mais longa que larga ao nível dos olhos e distintamente mais longa que $o$ pronoto (1:0,58). Região anteocular seis vezes mais longa que a pós-ocular $(1: 0,16)$. Genas ligeiramente aguçadas apicalmente. Olhos em vista lateral ultrapassando o nível da superfície ventral, e distantes da superfície dorsal da cabeça. Proporção entre a largura de um olho e a região interocular =1:1,16. Tubérculos anteníferos inseridos bem adiante do meio da região anteocular. Primeiro artículo antenal não atingindo o nível do ápice do clípeo. Proporções entre os artículos antenais $=1: 4.5$ : 3.5: 3. Proporções entre os segmentos do rostro = 1: 3.2: 1 . Pronoto castanho avermelhado. Lobo anterior com escultura bem marcada, tubérculos discais pouco aparentes. Ângulos ântero-laterais do colar muito divergentes, cilindrocônicos e grandes. Lobo posterior granuloso. Escutelo avermelhado, com processo apical aguçado, quase do mesmo comprimento do corpo do escutelo. Hemiélitros não alcançando o ápice do VIII tergito. Cório laranja, membrana cinza, clavo e veias marrom-escuro. Pernas castanho avermelhadas, com exceção dos trocânteres que são amarelados, fêmures com pequenos tubérculos. Conexivo castanho escuro, com uma mancha subtriangular alaranjada em cada segmento atingindo ventralmente a sutura conexival. Para descrição completa veja Carcavallo, Galvão \& Lent (1998).

Material tipo: depositado na Coleção Rodolfo Carcavallo do Instituto Oswaldo Cruz, Rio de Janeiro.

Habitat: peridomicílio

Distribuição: Mato Grosso 


\section{Triatoma klugi Carcavallo, Jurberg, Lent \& Galvão, 2001}

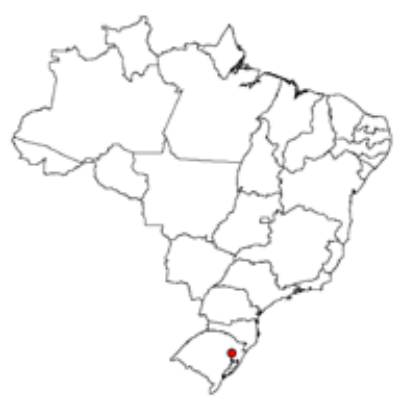

Etimologia: o epíteto específico klugi é uma homenagem a Johann Christoph Fiedrich Klug (1775-1856), entomólogo alemão.

Características gerais: comprimento total dos machos de 24 a $25 \mathrm{~mm}$, das fêmeas de 25 a $27 \mathrm{~mm}$. Coloração geral negra tendo manchas amarelas centrais em cada segmento do conexivo, parte externa do clavo e base do cório. Cabeça negra, suavemente granulosa; três vezes mais longa que larga ao nível dos olhos e distintamente mais longa que o pronoto. Região ante-ocular 3,5 a 4 vezes mais longa que a pós-ocular. Genas rugosas e granulosas ultrapassando o ápice do clípeo. Olhos em vista lateral ultrapassando o nível da superfície ventral, e distantes da superfície dorsal da cabeça. Proporção entre a largura de um olho e a região interocular =1:1,5. Tubérculos anteníferos inseridos no meio da região anteocular. Primeiro artículo antenal não atingindo o nível do ápice do clípeo. Proporções entre os artículos antenais = 1:3,5:2,4:1,9 Rostro negro, proporções entre os segmentos do rostro $=1: 2,5: 1,2$. Pronoto preto brilhante, rugoso. Lobo anterior com tubérculos discais vestigiais, sem tubérculos laterais. Ângulos ântero-laterais divergentes, cônicos e aguçados. Lobo posterior rugoso. Escutelo muito rugoso com a depressão central muito profunda e o processo do escutelo cônico, pequeno e voltado para cima. Hemiélitros não atingindo o bordo posterior do abdômen, apenas a metade do VII urotergito. Cório amarelado com veias negras. Pernas uniformemente pretas, longas e delgadas, fêmures anteriores e médios com $1+1$ tubérculos pequenos na união do 1/4 apical com os 3/4 proximais. Fossetas esponjosas presentes nas tíbias anteriores e médias. Conexivo com mancha amarela no centro de cada segmento Para descrição completa veja Carcavallo et al. (2001).

Material tipo: depositado nas Coleções Herman Lent e Rodolfo Carcavallo do Instituto Oswaldo Cruz, Rio de Janeiro.

Habitat: os espécimes conhecidos foram coletados em frestas de rochas no morro Malakov no município de Nova Petrópolis, RS.

Distribuição: Rio Grande do Sul 


\section{Triatoma lenti Sherlock} \& Serafim, 1967

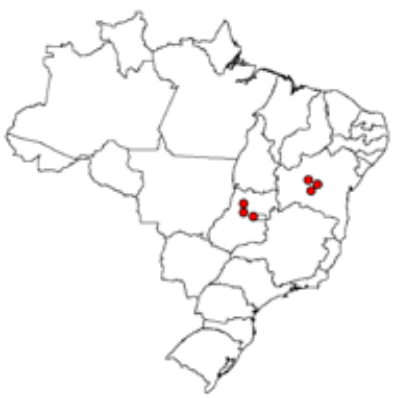

Etimologia: o epíteto específico lenti é uma homenagem a Herman Lent (1911-2004), notável entomólogo brasileiro e maior autoridade mundial em taxonomia de triatomíneos.

Sinônimos: Triatoma bahiensis Sherlock \& Serafim, 1967; Triatoma pessoai Sherlock \& Serafim, 1967; Triatoma pessoai var. bahiensis Sherlock \& Serafim, 1972.

Características gerais: comprimento total dos machos de 25 a 26 mm, das fêmeas de 26,5 a 27,5 mm. Coloração geral negra tendo manchas amarelas ou alaranjadas no pescoço conexivo e raramente no cório. Pilosidade curta e esparsa. Cabeça negra, suavemente granulosa; duas vezes mais longa que larga ao nível dos olhos $(1: 0,45-0,50)$ e distintamente mais longa que o pronoto $(1: 0,80$ $0,85)$. Região ante-ocular 4 a 5 vezes mais longa que a pós-ocular (1:0,20-0,25). Genas ultrapassando ligeiramente o ápice do clípeo. Olhos pequenos, em vista lateral não alcançando o nível da superfície ventral, e distantes do nível da superfície dorsal da cabeça. Proporção entre a largura de um olho e a região interocular $=1: 2,1-2,4$. Tubérculos anteníferos longos e finos com ápice situados mais além do no meio da região anteocular. Primeiro artículo antenal atingindo o nível do ápice do clípeo. Proporções entre os artículos antenais $=1: 3,4-4,25: 2,1-2,5: 1,8-2,1$. Rostro negro com primeiro segmento atingindo o nível do ápice do tubérculo antenífero, proporções entre os segmentos do rostro $=1: 1,7-$ 2,1:0,7-0,9. Pronoto totalmente negro, não granuloso. Lobo anterior sem tubérculos discais ou laterais. Ângulos ântero-laterais curtos e arredondados apicalmente. Escutelo com processo tão longo quanto o corpo principal. Hemiélitros dos machos geralmente não ultrapas-

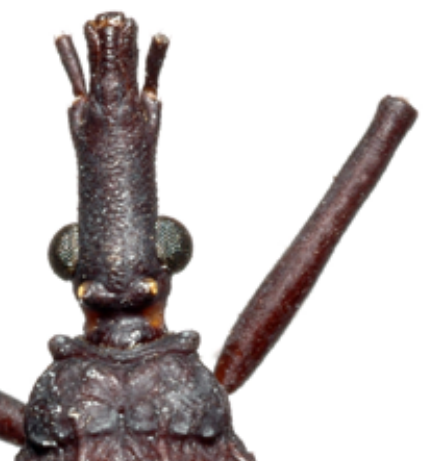
sando a base ou o meio do VII urotergito, nas fêmeas atingindo o ápice ou o meio do Vl urotergito. Cório e clavo negros, membrana castanho escuro com veias negras. Pernas uniformemente negras, longas e delgadas, fêmures anteriores e medianos com 1 par de pequenos dentículos subapicais. Fossetas esponjosas presentes nas tíbias anteriores e médias dos machos, ausentes nas fêmeas. Conexivo negro com mancha amarela ou alaranjada de tamanho variável. Para descrição completa veja Lent \& Wygodzinsky (1979).

Material tipo: de lenti, pessoai e bahiensis depositados na Coleção Herman Lent do Instituto Oswaldo Cruz, Rio de Janeiro.

Habitat: em domicílios, currais de cabras e entre rochas.

Distribuição: Bahia e Goiás. 


\section{Triatoma maculata}

\section{(Erichson, 1848)}

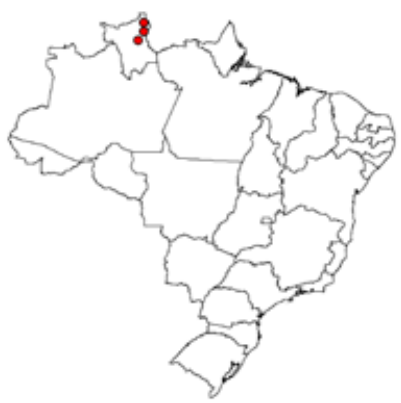

Sinônimos: Conorrhinus maculatus Erichson in Schomburgk,1848, Conorhinus maculatus Stål, 1859; Conorhinus immaculata Patton \& Cragg, 1913; Eutriatoma maculata Pinto, 1931.

Características gerais: comprimento total dos machos de 16,5-21,5 mm, das fêmeas de 17,5-22 mm. Coloração geral castanho escuro ou negra com manchas amarelas, alaranjadas ou avermelhadas na cabeça, pescoço, tórax, cório e conexivo. Tegumento quase glabro. Pilosidade curta e esparsa. Cabeça negra com mancha vermelho-alaranjada dorsal mais ou menos extensa em forma de Y sobre o clípeo, as genas, as jugas e prolongando-se, as vezes, entre os olhos, muito raramente toda preta. Cabeça muito elevada atrás, na vista lateral; menos que duas vezes mais longa que larga ao nível dos olhos $(1: 0,6-0,7)$ e tão longa ou ligeiramente mais curta que o pronoto (1:1,01,1). Região ante-ocular 3 a 4 vezes mais longa que a pós-ocular (1:0.25-0.35). Genas ultrapassando nitidamente o ápice do clípeo. Olhos grandes, em vista lateral ultrapassando o nível da superfície ventral, e quase atingindo o nível da superfície dorsal da cabeça. Proporção entre a largura de um olho e a região interocular = 1:0,9-1,1. Tubérculos anteníferos situados ligeiramente além da metade da região anteocular. Primeiro artículo antenal aquém do nível do ápice do clípeo. Proporções entre os artículos antenais = 1:4,2-5,0:2,83,2:1,9-2,4. Rostro negro, cerdas curtas e esparsas no primeiro e segundo artículos e muito numerosas e alongadas no terceiro. Proporções entre os artículos do rostro = 1:1,9-2,2:0,9-1.0. Pronoto castanho escuro ou negro. Lobo anterior totalmente negro ou com áreas alaranjadas ou amareladas sobre os tubérculos discais e laterais, manchas claras pequenas presentes em cada lado, entre a base das carenas longitudinais e os tubérculos laterais. Lobo posterior negro, com três pares, ou ao menos um par, de manchas alaranjadas na maioria dos espécimes. Ângulos ântero-laterais alongados, subtriangulares. Pleura negra com manchas alaranjadas. Escutelo negro, com processo tão longo quanto o corpo principal. Hemiélitros castanho claro com veias negras, 
atingindo ou se aproximando do ápice do VII urotergito, nos machos e fêmeas. Pernas uniformemente negras, fêmures anteriores e medianos com 1 par de pequenos dentículos subapicais. Fossetas esponjosas presentes nas tíbias anteriores e médias dos machos, ausentes nas fêmeas. Conexivo amarelada, alaranjado ou avermelhado com faixa escura larga situada sobre a sutura interconexival. Processo do endosoma da genitália masculina sem dentículos no ápice. Para descrição completa veja Lent \& Wygodzinsky (1979).

Material tipo: depositado no Zoologisches Museum, Berlim, Alemanha.

Habitat: vários ecótopos silvestres como ocos de árvores, sob cascas de árvores, ninhos e palmeiras, coloniza frequentemente o peridomicílio e eventualmente os domicílios (Carcavallo et al. 1998, Luitgards-Moura 2001).

Distribuição: Roraima.

Distribuição fora do Brasil: Aruba, Bonaire, Curaçao, Colômbia, Guiana, Guiana Francesa, Suriname e Venezuela. 


\section{Triatoma matogrossensis Leite \& Barbosa, 1953}

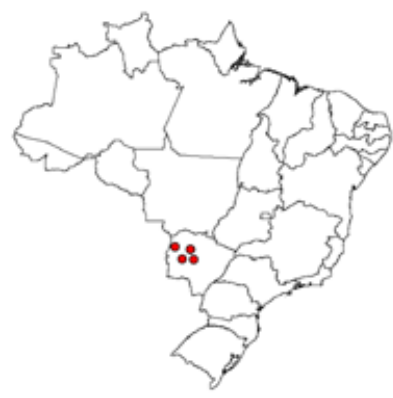

Etimologia: o epíteto específico matogrossensis é uma referência ao estado do Mato Grosso do Sul, local de captura do material tipo.

Sinônimos: Triatoma (Eutriatoma) matogrossensis Leite \& Barbosa, 1953

Características gerais: comprimento total dos machos de 24,5 a $28 \mathrm{~mm}$, das fêmeas de 28 a $30 \mathrm{~mm}$. Coloração geral castanho escuro ou castanho escuro avermelhado com áreas castanho claro avermelhadas no pescoço, lobo posterior do pronto, hemiélitros, pernas e conexivo. Pilosidade curta e esparsa. Cabeça castanho escuro, mais que duas vezes mais longa que larga ao nível dos olhos $(1: 0,4)$ e muito mais longa que o pronoto (1:0,75). Região ante-ocular 4 a 5 vezes mais longa que a pós-ocular (1:0.2-0.25). Genas ultrapassando nitidamente o ápice do clípeo. Olhos em vista lateral quase atingindo o nível da superfície ventral, e distantes do nível da superfície dorsal da cabeça. Proporção entre a largura de um olho e a região interocular $=1: 1,3-1,7$. Tubérculos anteníferos situados na metade da região anteocular. Primeiro artículo antenal aquém do nível do ápice do clípeo. Proporções entre os artículos antenais $=1: 4,7-5,1: 3,1-3,6: 2,4$ 2,8 . Rostro castanho amarelado. Proporções entre os artículos do rostro = 1:2.5-2.8:1.2-1.4. Pronoto castanho escuro ou castanho avermelhado com 1+ 1 manchas mais claras nos húmeros. Lobo anterior com tubérculos discais pequenos e laterais não desenvolvidos. Ângulos ântero-laterais curtos. Escutelo curto, com processo com cerca de metade do comprimento do corpo principal. Hemiélitros atingindo ou se aproximando do bordo posterior do VII urotergito, nos machos e da base do VII urotergito nas fêmeas. Clavo castanho escuro na base, cor de palha na metade apical. Pernas castanho claro amarelada com manchas ou anelações escuras, fêmures anteriores e medianos com 1 par de pequenos dentículos subapicais. Fossetas esponjosas presentes nas tíbias anteriores e médias dos machos, ausentes nas fêmeas. Conexivo amarelado ou castanho amarelado com estreita faixa escura situada sobre ou ao longo da margem posterior da sutura inter-segmentar. Para descrição completa veja Lent \& Wygodzinsky (1979).

Material tipo: depositado na Coleção Herman Lent do Instituto Oswaldo Cruz, Rio de Janeiro.

Habitat: desconhecido.

Distribuição: Mato Grosso do Sul 


\section{Triatoma melanica Costa, Argolo \& Felix, 2006}

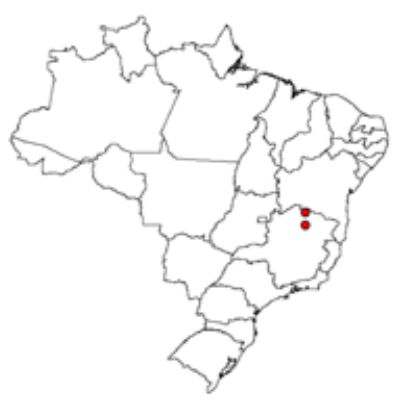

Etimologia: o epíteto específico melanica vem do grego "melas" que significa negro, uma referência às manchas negras presentes no corpo do inseto.

Sinônimos: Triatoma brasiliensis melanica Neiva \& Lent, 1941.

Características gerais: comprimento total dos machos de 20,3 a 24 mm, das fêmeas de 21 a $24 \mathrm{~mm}$. Coloração geral castanho amarelado. Cabeça negra, duas vezes mais longa que larga ao nível dos olhos (1:0,40-0.65). Região anteocular cinco vezes mais longa que a pós-ocular $(1: 0,2)$. Genas ultrapassando ligeiramente o ápice do clípeo. Olhos em vista lateral não alcançando o nível da superfície ventral da cabeça e distantes do nível da superfície dorsal. Proporção entre a largura de um olho e a região interocular 1:1,40-2,35. Tubérculos anteníferos inseridos ligeiramente após a metade da região anteocular. Primeiro artículo antenal atingindo o nível do ápice do clípeo. Proporções entre os artículos antenais $=1: 4,2-5,8: 2,2-3,8: 2,0$ 2,2. Rostro robusto e negro. Primeiro artículo rostral alcançando o nível do ápice do tubérculo antenífero, segundo artículo o nível do meio dos olhos. Proporções entre os artículos do rostro = 1:1,5-3,8:0,6-1,6. Pescoço negro com um par de manchas claras laterais. Pronoto negro e amarelo. Lobo anterior com tubérculos discais amarelos e tubérculos laterais ausentes. Lobo posterior com um par de nítidas marcas trapezoidais amareladas. Carenas submedianas evanescentes no quarto posterior. Ângulos humerais arredondados. Escutelo negro, processo apical tão longo quanto o corpo principal do escutelo e com o ápice amarelo. Hemiélitro com cório amarelo claro, células discais inteiramente ou quase inteiramente castanho escuro; clavo inteiramente escuro; membrana esfumaçada, castanho claro amarelada; veias da membrana castanho. Pernas negras com manchas amareladas nos trocânteres; ápices das tíbias ligeiramente amarelados. Fêmures anteriores e medianos com pequenos dentículos subapicais. Fossetas esponjosas presentes somente nas tíbias anteriores dos machos, ausentes nas fêmeas. Abdômen ventral negro. Conexivo com áreas amarelas e áreas escuras de tamanho idêntico, ocupando toda a largura do conexivo; a área escura abrange a sutura itersegmental. Abdômen das fêmeas muito largo com as porções laterais dos urotergitos expostas. Para descrição completa veja Costa et al. (2006).

Material tipo: desconhecido. Os espécimes utilizados na redescrição estão depositados na Coleção Entomológica do Instituto Oswaldo Cruz, Rio de Janeiro.

Habitat: ambiente silvestre, raramente invade domicílios.

Distribuição: Minas Gerais. 


\section{Triatoma melanocephala} Neiva \& Pinto, 1923

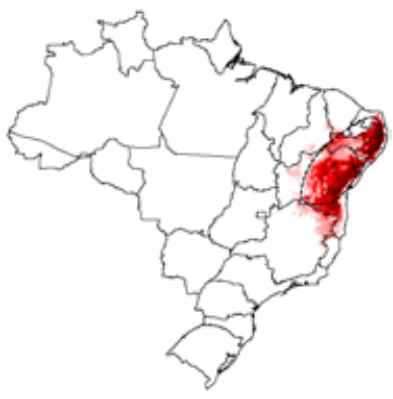

Etimologia: o epíteto específico melanocephala vem do grego "melas" que significa negro e "kephale" que significa cabeça, uma referência à cabeça negra do inseto.

Características gerais: comprimento total dos machos de 25,5 a 26,5 mm, das fêmeas de $28 \mathrm{~mm}$. Coloração geral castanho escuro a negro com manchas amareladas no pescoço, pronoto, hemiélitros e conexivo. Pilosidade curta, esparsa e pouco visível. Cabeça negra, rugosa e delicadamente granulosa, menos que duas vezes mais longa que larga ao nível dos olhos $(1: 0,6)$ e aproximadamente tão longa quanto o pronoto. Região anteocular de duas e meia a três vezes mais longa que a pós-ocular (1:0,3-0,4). Genas atingindo ou ultrapassando ligeiramente o ápice do clípeo. Olhos em vista lateral alcançando o nível da superfície ventral da cabeça e distantes do nível da superfície dorsal. Proporção entre a largura de um olho e a região interocular 1:1,8-2,2. Tubérculos anteníferos inseridos ligeiramente após a metade da região anteocular. Primeiro artículo antenal ultrapassando levemente o nível do ápice do clípeo. Proporções entre os artículos antenais $=1: 3: 2,5:$ ? . Rostro tão negro quanto a cabeça. Proporções entre os artículos do rostro = 1:1,6-1,8:0,7-0,8. Pronoto castanho escuro com 1+1 manchas amareladas ovais na parte anterior do lobo posterior. Lobo anterior com um par de pequenos tubérculos discais e laterais. Ângulos humerais arredondados com bordo externo amarelado. Escutelo uniformemente negro, processo apical tão longo quanto o corpo principal do escutelo. Hemiélitro castanho, atingindo o bordo posterior do sétimo urotergito, base do clavo e células do cório, especialmente aquelas limitadas pela Sc, R+M e R e base das células da membrana, mais escuras. Veias predominantemente amarelas assim como uma nítida área alongada próximo a base do cório, adjacente à sutura claval. Segmentos conexivais com as manchas negras de formato irregular localizadas sobre as suturas inter-segmentares. Pernas negras. Para descrição completa veja Lent \& Wygodzinsky (1979).

Material tipo: depositado na Coleção Herman Lent do Instituto Oswaldo Cruz, Rio de Janeiro.

Habitat: adultos são encontrados ocasionalmente nos domicílios, habitats silvestres são desconhecidos.

Distribuição: Bahia, Paraíba, Pernambuco, Rio Grande do Norte e Sergipe. 


\section{Triatoma oliveirai}

\section{(Neiva, Pinto \& Lent, 1939)}

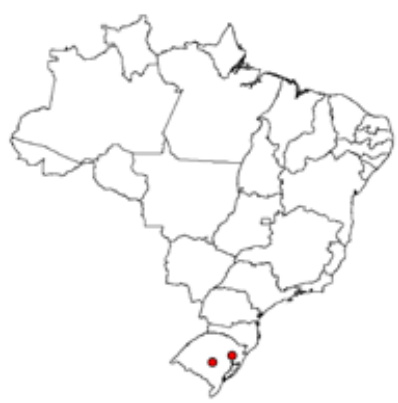

Etimologia: o epíteto específico oliveirai é uma homenagem a Gastão de Oliveira pioneiro nos estudos da doença de Chagas no Rio Grande do Sul.

Sinônimos: Eutriatoma oliveirai Neiva, Pinto \& Lent, 1939

Características gerais: comprimento dos machos de 25 a $27 \mathrm{~mm}$. Fêmea desconhecida. Coloração geral negra com manchas amareladas no pescoço, em alguns casos no pronoto e conexivo; hemiélitro amarelado. Pilosidade curta e esparsa; tegumento polido. Cabeça negra, rugosa e delicadamente granulosa, cerca de duas vezes mais longa que larga ao nível dos olhos(1:0,45) e muito mais longa que o pronoto $(1: 0,75-0,80)$. Região anteocular três vezes mais longa que a pós-ocular (1:0,3). Genas ultrapassando consideravelmente o ápice do clípeo. Olhos pequenos, em vista lateral não alcançando o nível da superfície ventral da cabeça e distantes do nível da superfície dorsal. Proporção entre a largura de um olho e a região interocular 1:2. Tubérculos anteníferos inseridos na metade da região anteocular. Primeiro artículo antenal aproximando-se do nível do ápice do clípeo. Proporções entre os artículos antenais $=1: 4,0-4,2: 2,7-3,0: 2,2$. Rostro castanho avermelhado escuro. Proporções entre os artículos do rostro $=1: 1,95-2,1: 1,0-1,2$. Pescoço negro com um par de manchas claras laterais. Pronoto negro com 1+1 manchas amareladas no húmero. Lobo anterior com 1+1 tubérculos discais pequenos e 1+1 tubérculos laterais negros ou alaranjados. Ângulos humerais arredondados. Escutelo negro, processo apical curto com cerca de metade do comprimento do corpo principal do escutelo, obliquo, subcônico com ápice arredondado. Hemiélitro curto atingindo ou ultrapassando levemente o limite entre o sexto e sétimo urotergitos. Amarelado tanto no cório quanto na membrana, sem manchas escuras, somente as veias são nitidamente escuras. Clavo com áreas escuras na base e margem externa. Pernas negras, fêmures de todos os pares com um par de pequenos dentículos subapicais. Fossetas esponjosas ausentes no macho. Abdome muito largo com as porções externas dos urotergitos expostas. Conexivo negro com grandes áreas amarelas. Para descrição completa veja Lent \& Wygodzinsky (1979).

Material tipo: depositado na Coleção Herman Lent do Instituto Oswaldo Cruz, Rio de Janeiro.

Habitat: essa espécie foi encontrada em ninho de preá (Cavia aperea).

Distribuição: Rio Grande do Sul. 


\section{Triatoma petrocchiae Pinto \& Barreto, 1925}

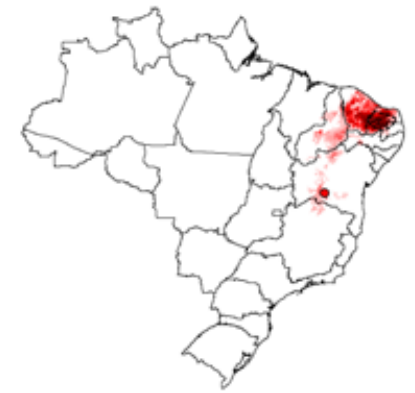

Etimologia: o epíteto específico petrocchiae é uma homenagem a Juana M. Petrocchi (1893-1925), entomóloga Argentina.

Características gerais: comprimento dos machos de 17 a 21,5 mm, das fêmeas de 18 a 23 $\mathrm{mm}$. Coloração geral castanho escuto com manchas amareladas no pronoto, escutelo, hemiélitro e conexivo. Tegumento aparentemente glabro, com raras cerdas curtas e esparsas. Cabeça negra, delicadamente rugosa e granulosa, cerca de duas vezes mais longa que larga ao nível dos olhos $(1: 0,40-0,45)$ e muito mais longa que o pronoto $(1: 0,70-0,75)$. Região anteocular quatro vezes mais longa que a pós-ocular (1:0,25). Genas ultrapassando consideravelmente o ápice do clípeo. Olhos em vista lateral não alcançando o nível da superfície ventral da cabeça e distantes do nível da superfície dorsal. Proporção entre a largura de um olho e a região interocular 1:1,8-2,5. Tubérculos anteníferos inseridos ligeiramente adiante da metade da região anteocular. Primeiro artículo antenal curto não alcançando o nível do ápice do clípeo. Proporções entre os artículos antenais= 1:3,3-4,2:2,3-2,8:2,1-2,5. Rostro estreito, quase glabro, exceto por um grupo de longas cerdas no ápice do terceiro artículo. Proporções entre os artículos do rostro = 1:2,22,8:1,1-1,2. Pescoço negro com um par de manchas claras laterais. Pronoto castanho escuro amarelado no colar, nas calosidades discais e em alguns casos nas margens laterais do lobo anterior. Lobo anterior com tubérculos discais reduzidos a calosidades subovais e tubérculos laterais ausentes. Ângulos humerais arredondados, quase angulares. Escutelo castanho escuro, processo apical curto com cerca de três terços do comprimento do corpo principal do escutelo. Hemiélitro atingindo ou ultrapassando quase atingindo o ápice do sétimo urotergito. Cório castanho escuro, membrana amarelo-esbranquiçado com grande mancha central mais escura. Veias escuras. Pernas negras, fossetas esponjosas ausentes em ambos os sexos. Conexivo castanho escuro com grande mancha amarela ocupando dois terços de cada segmento. Para descrição completa veja Lent \& Wygodzinsky (1979).

Material tipo: depositado na Coleção Herman Lent do Instituto Oswaldo Cruz, Rio de Janeiro.

Habitat: ninhos de mocós (Kerodon rupestris), eventualmente encontrada nos domicílios.

Curiosidades: espécie similar a T. brasiliensis da qual se diferencia por ter a cabeça muito longa, o primeiro artículo antenal mais curto, o rostro praticamente glabro e pela ausência de fossetas esponjosas em ambos os sexos. Embora ocorrendo em simpatria as duas espécies não hibridizam.

Distribuição: Bahia, Ceará, Paraíba, Pernambuco e Rio Grande do Norte. 


\section{Triatoma pintodiasi} Jurberg, Cunha \& Rocha, 2013

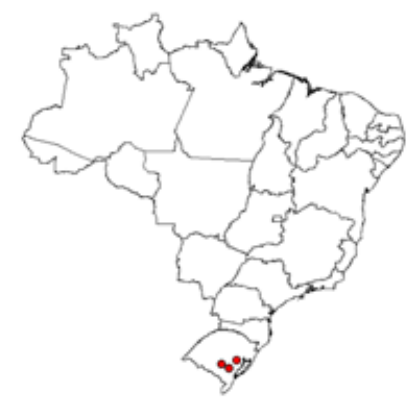

Etimologia: O epíteto específico pintodiasi é uma homenagem a João Carlos Pinto Dias, médico que dedicou sua carreira as pesquisas sobre epidemiologia e controle da doença de Chagas.

Características gerais: Cabeça mais longa que o pronoto 1:0,79, região ante-ocular mais longa que a pós-ocular 1:0,39. Relação da largura do olho e a região interocular 1:1,66. Antenas com o primeiro artículo muito curto, não ultrapassando a região mediana das genas. Proporção entre os artículos da antena 1:4,13:2,66:2,33. Rostro de cor castanho-clara, primeiro artículo atingindo a região mediana das genas, $2^{\circ}$ segmento longo, atingindo a região mediana dos olhos e terceiro artículo menor que o $2^{\circ}$, com o ápice tocando o bordo anterior do sulco estridulatório; proporções dos artículos do rostro 1:2,5:2,25. Pronoto com lobo anterior totalmente negro, lobo posterior totalmente alaranjado/amarelado. Ângulo ântero-lateral levemente projetado, acuminado. Tubérculos discais inaparentes. Proporção entre o comprimento e a largura do pronoto 1:1,5. Escutelo triangular, negro, superfície esculturada e brilhante; processo do escutelo de bordos paralelos e ápice arredondado. Proporção entre a largura na base e o comprimento 1:0,92. Hemiélitros com a membrana, maior parte do clavo e pequena porção do cório castanho-escuras; base do clavo clara; maior parte do cório alaranjada; nervuras da membrana castanho-escuro, tornando-se alaranjadas ao adentrarem no cório. Para descrição completa veja Jurberg et al. (2013).

Material tipo: depositado na Coleção Herman Lent do Instituto Oswaldo Cruz, Rio de Janeiro.

Habitat: rochas e fendas em muros de pedras.

Distribuição: Rio Grande do Sul. 


\section{Triatoma platensis Neiva, 1913}

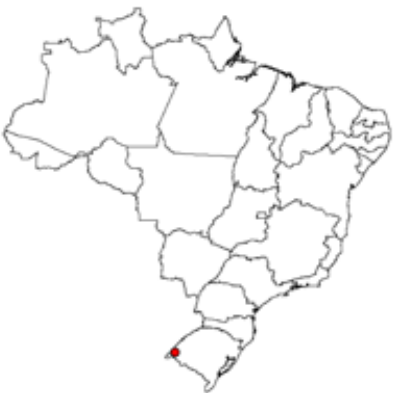

Etimologia: o epíteto específico platensis é uma referência a região de ocorrência da espécie.

Sinônimos: Triatoma rosenbuschi Mazza, 1936

\section{Características gerais: com-}

primento dos machos de 22 a $24 \mathrm{~mm}$, das fêmeas de 22,5 a $26 \mathrm{~mm}$. Inseto robusto e fortemente esclerotizado. Coloração geral castanho escuro fosco com manchas amareladas no pescoço e conexivo. Pilosidade dourada muito densa. Cabeça castanho escuro avermelhado, densamente pilosa com cerdas direcionadas para frente, menos de duas vezes mais longa que larga ao nível dos olhos $(1: 0,60-0,65)$ e ligeiramente menor que o pronoto $(1: 1,1-1,2)$. Região anteocular três vezes mais longa que a pós-ocular $(1: 0,3)$. Genas ultrapassando consideravelmente o ápice do clípeo. Olhos em vista lateral atingindo o ultrapassando ligeiramente o nível da superfície ventral da cabeça e distantes do nível da superfície dorsal. Proporção entre a largura de um olho e a região interocular 1:1,5-2,0. Tubérculos anteníferos inseridos ligeiramente adiante da metade da região anteocular. Primeiro artículo antenal curto não alcançando o nível do ápice do clípeo. Proporções entre os artículos antenais $=1: 2,8-3,4: 2,6-2,8: 1,5-1,7$. Rostro tão escuro quanto a cabeça. Proporções entre os artículos do rostro = 1:1,7-2,0:0,9-1,1. Pescoço castanho escuro com um par de manchas claras laterais. Pronoto castanho fosco, lobo anterior com 1+1 tubérculos discais e 1+1 tubérculos laterais densamente recobertos por cerdas, lobo posterior recoberto por cerdas.

Ângulos ântero-laterais curtos e lateralmente direcionados. Base do escutelo com 1+1 proeminências voltadas para a margem posterior do pronoto. Processo apical do escutelo com cerca de três quintos do comprimento do corpo principal do escutelo. Hemiélitro atingindo ou ultrapassando levemente o ápice do sétimo urotergito. Pernas castanho avermelhado escuro, fossetas esponjosas presentes nos fêmures anteriores e medianos dos machos, ausentes nas fêmeas. Conexivo com mancha amarela na metade posterior de cada segmento. Para descrição completa veja Lent \& Wygodzinsky (1979).

Material tipo: de T. platensis depositado no Museo Argentino de Ciencias Naturales; de T.rosenbuschi depositado na Mision de Estudios de Patologfa Regional, Buenos Aires, Argentina.

Habitat: ninhos de aves (Furnariidae) e mais raramente em ninhos de outras aves e refúgios de roedores, ocasionalmente encontrada em peridomicílio (galinheiros, currais) (Carcavallo et al. 1998, Salvatella et al. 1991).

Curiosidades: seus ovos são colocados aderidos ao substrato.

Distribuição: Rio Grande do Sul.

Distribuição fora do Brasil: Argentina, Bolívia, Paraguai e Uruguai. 


\section{Triatoma pseudomaculata Corrêa \& Espínola, 1964}

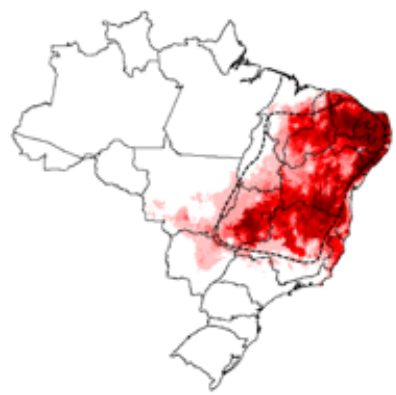

Etimologia: o epíteto específico pseudomaculata (pseudo $=$ falso) é uma referência à similaridade com T. maculata.

Sinônimos: Triatoma pseudomaculata minasensis Espínola, 1974

Características gerais: comprimento total dos machos de 17 a $19 \mathrm{~mm}$, das fêmeas de 19 a $20 \mathrm{~mm}$. Coloração geral castanho escuro ou negro com manchas amarelas, alaranjadas ou avermelhadas no pescoço, tórax, cório e conexivo. Tegumento quase glabro. Pilosidade curta e esparsa. Cabeça uniformemente negra, menos elevada atrás, na vista lateral do que em T. maculata; menos que duas vezes mais longa que larga ao nível dos olhos (1: 0,6-0,7) e tão longa quanto o pronoto (1:1). Região ante-ocular 3 vezes mais longa que a pós-ocular (1:0,30-0,35). Genas ultrapassando nitidamente o ápice do clípeo. Olhos grandes, em vista lateral ultrapassando o nível da superfície ventral, e quase atingindo o nível da superfície dorsal da cabeça. Proporção entre a largura de um olho e a região interocular $=1: 1,1-1,4$. Tubérculos anteníferos situados ligeiramente além da metade da região anteocular. Primeiro artículo antenal não atingindo o nível do ápice do clípeo. Proporções entre os artículos antenais = 1:4,0-4,8:2,4-3,6:1,8-2,6. Rostro negro, cerdas curtas e esparsas no primeiro e segundo artículos e muito numerosas e alongadas no terceiro. Proporções entre os artículos do rostro = 1:2,4-3,1:1,0-1,1. Pronoto castanho escuro ou negro com áreas alaranjadas ou amareladas. Tubérculos discais e laterais do lobo anterior amarelados. Lobo posterior negro com três pares de manchas amareladas ou alaranjadas. Ângulos ântero-laterais proeminentes, alongados, subtriangulares ou cônicos. Pleura negra, na maioria dos espécimes com manchas alaranjadas

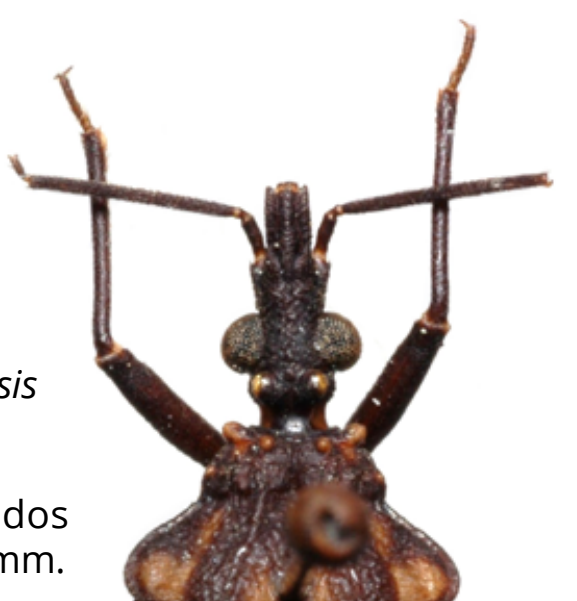
na região posterior (ausente em alguns espécimes). Escutelo negro, com processo tão longo quanto o corpo principal. Hemiélitros castanho escuro ou negro, quase atingindo ou em alguns machos ultrapassando o ápice do VII urotergito. Pernas uniformemente negras, fêmures anteriores cerca de cinco vezes mais longo que largo; fêmures anteriores e medianos com um par de pequenos dentículos subapicais. Fossetas esponjosas presentes nas tíbias anteriores e médias dos machos, ausentes nas fêmeas. Conexivo amarelado, alaranjado ou avermelhado com faixa escura larga situada sobre a sutura interconexival. Processo do endosoma da genitália masculina com dentículos no ápice. Para descrição completa veja Lent \& Wygodzinsky (1979).

Material tipo: depositado na Coleção Herman Lent do Instituto Oswaldo Cruz, Rio de Janeiro.

Habitat: domicílios e peridomicílios, em cercas construídas com galhos secos, associada aos cactus "Mandacaru" (Cereus jamacaru).

Distribuição: Alagoas, Bahia, Ceará, Distrito Federal, Goiás, Maranhão, Minas Gerais, Mato Grosso, Mato Grosso do Sul, Paraíba, Pernambuco, Piauí, Rio Grande do Norte, Sergipe e Tocantins. 


\section{Triatoma rubrofasciata (De Geer, 1773)}

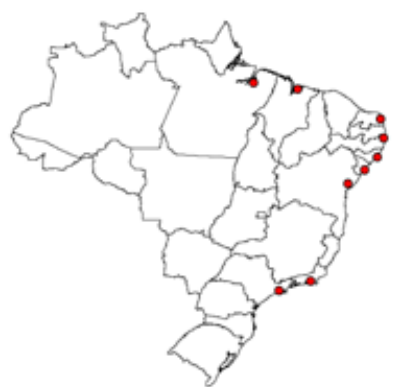

Etimologia: o epíteto específico rubrofasciata vem do latim "ruber, rubra, rubrum" que significa vermelho, uma referência às manchas avermelhadas presentes no corpo do inseto.

Sinônimos: Cimex rubro-fasciatus De Geer, 1773; Cimex variegatus Drury, 1773; Reduvius gigas Fabricius, 1775; Cimex gigas Gmelin, 1778; Cimex claviger Gmelin, 1778; Cimex erythrozonias Gmelin, 1778; Nabis gigas Latreille, 1804; Conorhimus gigas Laporte, 1832; Reduvius giganti Klug in Meyen, 1834; Conorhimus gigas Laporte, 1832; Triatoma gigas Laporte, 1833; Reduvius (Conorhinus) variegatus Westwood, 1837; Conorhinus rubrofasciatus Amyat \& Serville, 1843; Conorhinus stalii Signoret, 1860; Conohrinus variegatus Stal, 1872; Conohrinus limbatus Schouteden, 1907 (nomen nudum); Triatoma rufofasciata Van Duzee, 1916; Triatoma variegata Neiva, 1914; Triatoma evandroi Figueredo, 1938.

Características gerais: comprimento total dos machos de 19,5 a 24 $\mathrm{mm}$, das fêmeas de 20 a $25 \mathrm{~mm}$. Coloração geral castanho escuro ou negro com manchas amarelas, alaranjadas ou avermelhadas no pescoço, pronoto, cório e conexivo. Tegumento granuloso. Pilosidade curta e inaparente. Cabeça fortemente granulosa dorsalmente, uniformemente negra, menos que duas vezes mais longa que larga ao nível dos olhos (1: 0,67) e ligeiramente mais curta que o pronoto $(1: 1,1)$. Região ante-ocular 2,5 vezes mais longa que a pós-ocular $(1: 0,35)$. Olhos em vista lateral ultrapassando o nível da superfície ventral, mas distantes do nível da superfície dorsal da cabeça. Proporção entre a largura de um olho e a região interocular =1:1,9-2,2. Tubérculos anteníferos situados na metade da região anteocular. Primeiro artículo antenal ultrapassando nitidamente o ápice do clípeo. Proporções entre os artículos antenais = 1:3,8-4,0:2,2-2,6:1,6-1,9. Rostro abundantemente piloso, cerdas curtas no primeiro e na metade basal do segundo artículo e mais longas no terceiro. Proporções entre os artículos do rostro

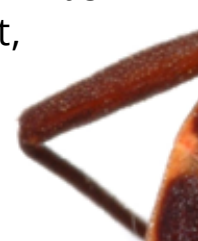
$=1: 1,6-1,7: 0,6$. Pronoto castanho escuro ou negro com as laterais e ângulos ântero-laterais alaranjados ou avermelhados. Tubérculos discais e laterais do lobo anterior ausentes. Proesterno, meso e meta pleuras granulosos. Processo apical do escutelo avermelhado em alguns espécimes, com cerca de duas a três vezes o comprimento do corpo principal. Hemiélitro castanho escuro ou negro, de comprimento variável, na maioria dos espécimes atingindo a base ou a metade do VII urotergito, mas em alguns machos pode atingir a porção apical desse urotergito. Pernas uniformemente negras, fêmures anteriores cerca de cinco vezes mais longo que largo; fêmures anteriores e medianos com dois a quatro pequenos dentículos subapicais pouco perceptíveis. Fossetas esponjosas presentes nas tíbias anteriores e médias dos machos, ausentes nas fêmeas. Conexivo negro com bordos e região da sutura interconexival alaranjada ou avermelhada. Para descrição completa veja Lent \& Wygodzinsky (1979). 
Material tipo: de rubro-fasciatus e stalii, depositado na coleção do Naturhistoriska Riksmuseet, Estocolmo, Suécia, os demais desconhecidos.

Habitat: domicílios.

Curiosidades: espécie intimamente associada com ratos, sua distribuição geográfica é atribuída ao transporte marítimo que a disseminou junto com esses animais pelas regiões portuárias dos trópicos. Espécie facilmente diferenciada das outras do gênero Triatoma pela combinação do primeiro artículo antenal longo com a nítida granulação da cabeça e tórax e pelo padrão cromático do pronoto com manchas laterais sempre perceptíveis.

Distribuição: Alagoas, Bahia, Maranhão, Pará, Paraíba, Pernambuco, Rio de Janeiro, Rio Grande do Norte, São Paulo e Sergipe.

Distribuição fora do Brasil: única espécie de barbeiro considerada cosmopolita (tropicopolita) está distribuída por regiões portuárias de diversos países. 


\section{Triatoma rubrovaria (Blanchard, 1843)}

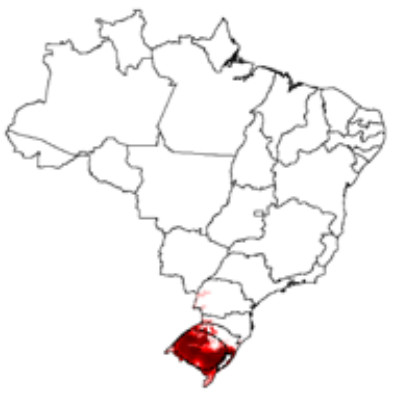

Etimologia: o epíteto específico rubrovaria vem do latim "ruber, rubra, rubrum" que significa vermelho e "varius, varia, varium" que significa diferente, variado, parcialmente colorido, uma clara referência à variabilidade das manchas avermeIhadas presentes no corpo do inseto.

Sinônimos: Conorhius rubro-varius Blancardh in Blanchard \& Brulle, 1843; Conorhinus rubroniger Stal, 1859; Triatoma gomesi Neiva \& Pinto, 1923; Eutriatoma rubrovaria Pinto, 1931; Eutriatoma gomesi Pinto, 1931; Triatoma (Eutriatoma) rubrovaria Lima, 1940; Triatoma burchi Mazza \& Jorg, 1944; Conorhinus phyllosoma Herrich-Schaeffer, 1848.

Características gerais: comprimento total dos machos de 21 a $24 \mathrm{~mm}$, das fêmeas de 22 a 25 $\mathrm{mm}$. Coloração geral negra com manchas alaranjadas ou avermelhadas no pescoço, pronoto, cório e conexivo. Tegumento pouco granuloso e com pilosidade curta, aparentando ser glabro. Cabeça longa e estreita, uniformemente negra, duas vezes mais longa que larga ao nível dos olhos $(1: 0,5)$ e ligeiramente mais longa que o pronoto $(1: 0,9)$. Região ante-ocular 3 vezes mais longa que a pós-ocular $(1: 0,3)$. Olhos em vista lateral ultrapassando levemente o nível da superfície ventral, mas distantes do nível da superfície dorsal da cabeça. Proporção

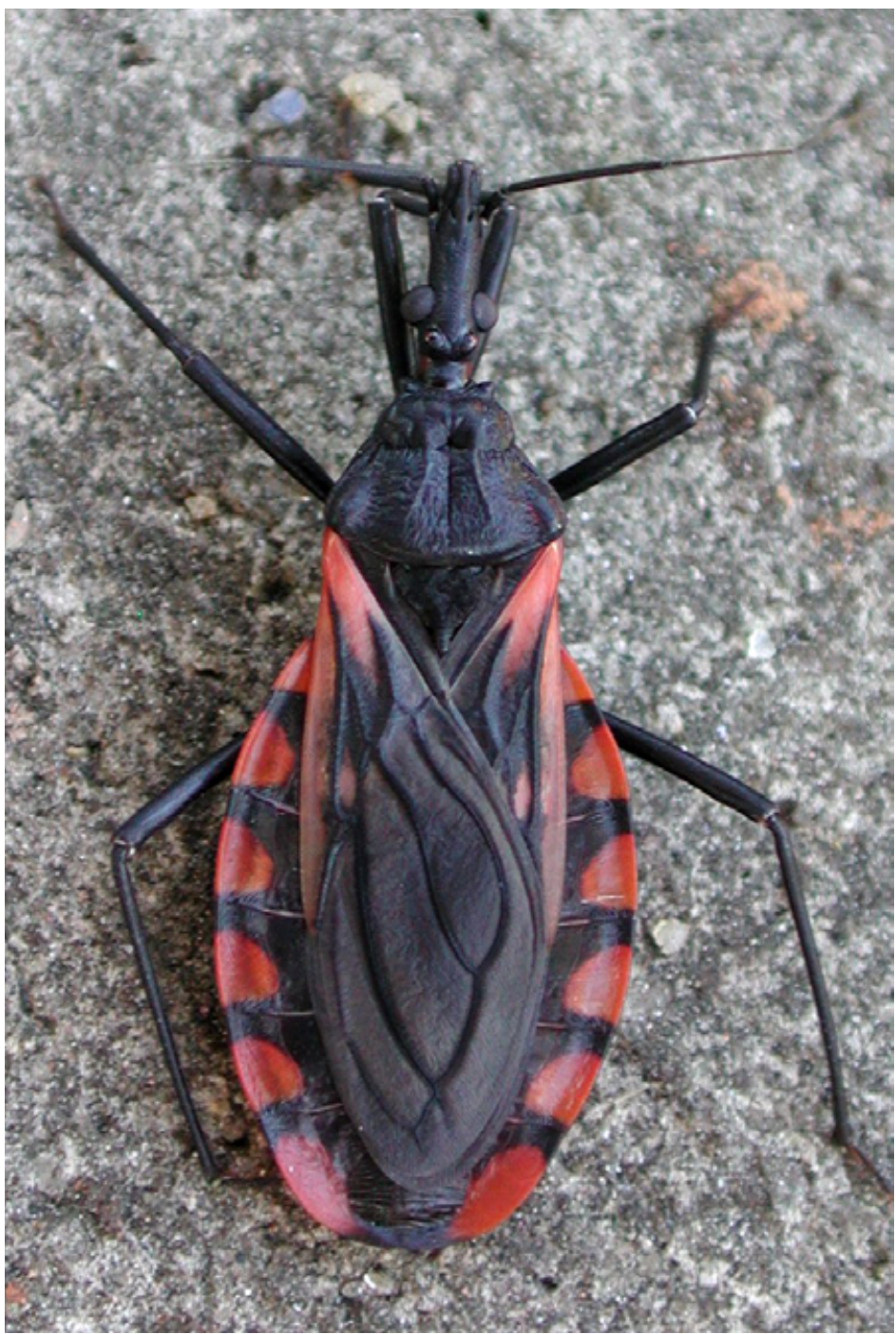
entre a largura de um olho e a região interocular = 1: 1,4-1,6. Tubérculos anteníferos situados ligeiramente além da metade da região anteocular. Primeiro artículo antenal não ultrapassando o ápice do clípeo. Proporções entre os artículos antenais = 1:3,8$4,5: 3,2: 2,6$. Rostro tão negro quanto a cabeça ou com o segundo e o terceiro artículos avermelhados. Proporções entre os artículos do rostro = 1:2,2-2,5:1,1-1,4. Pronoto com lobo anterior invariavelmente negro, lobo posterior raramente completamente negro ou completamente avermelhado apresentando nessa região grande variabilidade cromática mesclando áreas negras e avermelhadas. Escutelo negro com processo apical curto. Hemiélitro atingindo o ápice do VII urotergito nos machos e em algumas fêmeas, em outras fêmeas não se projetam além da metade do VII urotergito. Cório negro com manchas basais e subapicais claras, membrana castanho escura. Pernas uniformemente negras, fêmures anteriores cerca de seis a sete vezes mais longos que largos; fêmures anteriores e medianos com um par de pequenos dentículos subapicais. Fossetas esponjosas presentes nas tíbias anteriores e médias dos machos, ausentes nas fêmeas. Conexivo negro com grande mancha avermelhada ou alaranjada na região central de cada segmento. Para descrição completa veja Lent \& Wygodzinsky (1979). 
Material tipo: de rubrovarius, desconhecido; de rubroniger depositado no Zoologisches Museum, Berlim, Alemanha; de gomesi, depositado na Coleção Herman Lent, do Instituto Oswaldo Cruz, Rio de Janeiro; de bruchi depositado na Misión de Estudios de Patologia Regional, Buenos Aires, Argentina.

Habitat: rochas e fendas em muros de pedras. Adultos ocasionalmente tem invadido os domicílios (Almeida et al. 2002).

Curiosidades: espécie com grande variabilidade cromática no pronoto e cório. Espécie capaz de se alimentar da hemolinfa de outros artrópodes.

Distribuição: Rio Grande do Sul.

Distribuição fora do Brasil: Argentina e Uruguai. 


\section{Triatoma sherlocki Papa, Jurberg, Carcavallo, Cerqueira \& Barata, 2002}

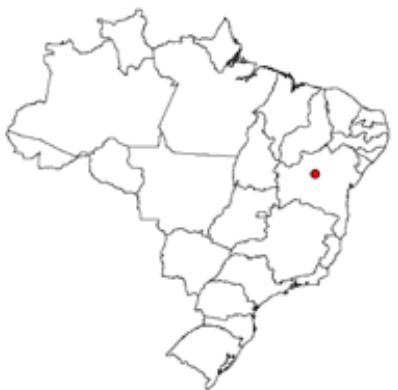

Etimologia: o epíteto específico sherlocki é uma homenagem a Ítalo Sherlock (1936-2009), parasitologista brasileiro.

\section{Características gerais:} comprimento total dos machos de 19 a $23 \mathrm{~mm}$, das

fêmeas de 19 a 26 mm. Coloração geral castanho escuro a negra com manchas alaranjadas ou avermelhadas semicirculares no conexivo. Clavo e cório escuros e membranas de coloração marrom a cinza. Cabeça negra, levemente granulosa duas vezes mais longa que larga ao nível dos olhos (1:0,5) e mais longa que o pronoto $(1: 0,7)$. Região ante-ocular 6 vezes mais longa que a pós-ocular $(1: 0,16)$. Olhos em vista lateral não atingem nível da superfície ventral nem da superfície dorsal da cabeça. Proporção entre a largura de um olho e a região interocular $=1: 1,2$. Tubérculos anteníferos situados ligeiramente além da metade da região anteocular. Primeiro artículo antenal não atingindo o ápice do clípeo. Proporções entre os artículos antenais $=1: 4,1: 2,5: 2,1$. Rostro tão escuro quanto a cabeça. Proporções entre os artículos do rostro $=1: 2: 1$. Pronoto com lobo anterior castanho escuro a negro, bordo do lobo posterior levemente mais claro, tubérculos discais presentes e laterais ausentes. Escutelo completamente negro e brilhante com processo apical curto. Conexivo castanho escuro com manchas alaranjadas ou avermelhadas centralizadas, não atingindo as suturas inter-segmentares. Hemiélitro curtos, atingindo o bordo anterior do VI urotergito. Cório escuro com veias de coloração marrom ou negra. Pernas uniformemente negras, longas e delgadas. fêmures anteriores, médios e posteriores com anelação alaranjada. Fossetas esponjosas ausentes. Para descrição completa veja Papa et al. (2002).

Material tipo: depositado na coleção da Faculdade de Saúde Pública, Universidade de São Paulo, São Paulo.

Habitat: rochas.

Distribuição: Bahia.

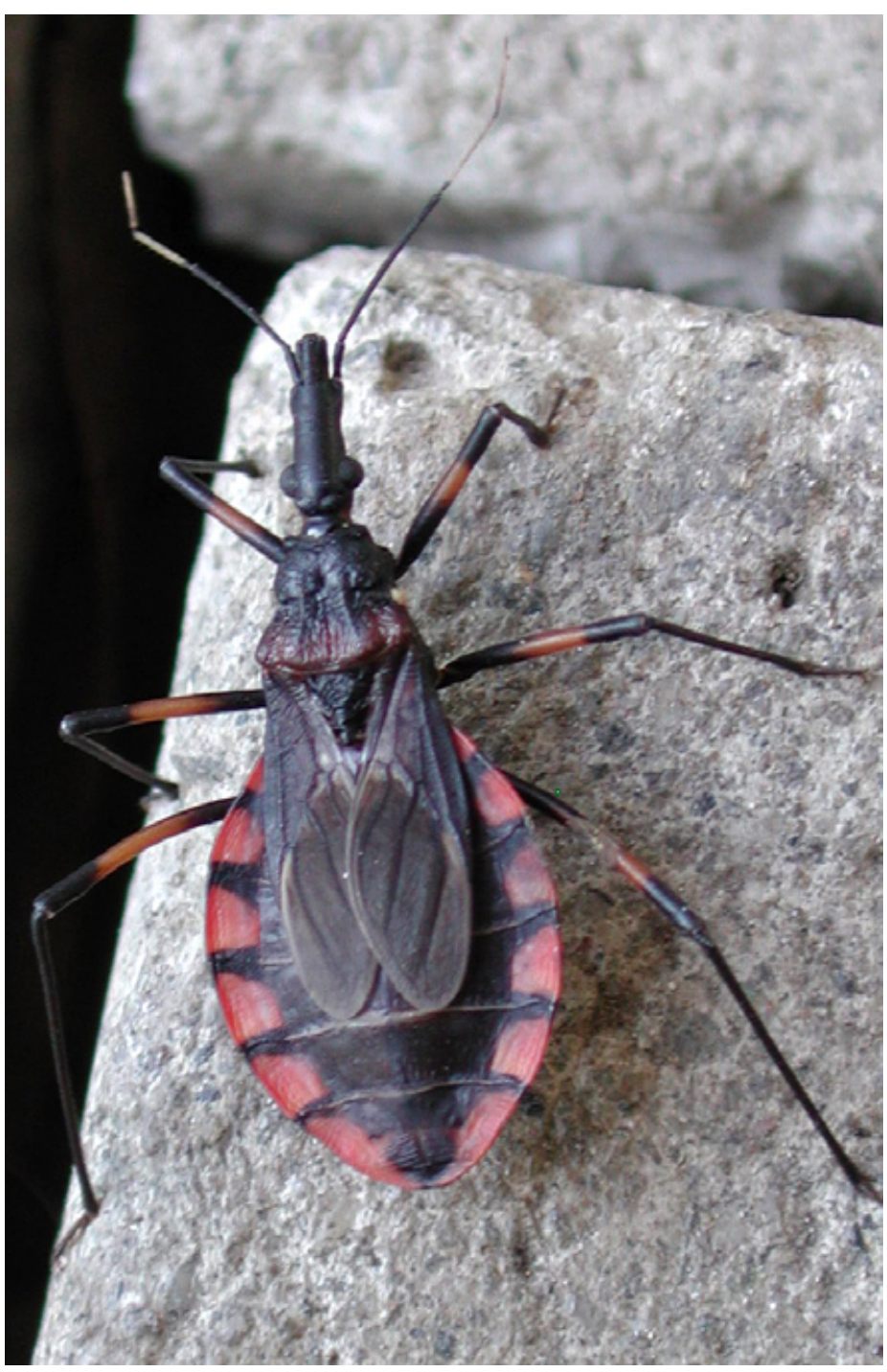




\section{Triatoma sordida} (Stål, 1859)

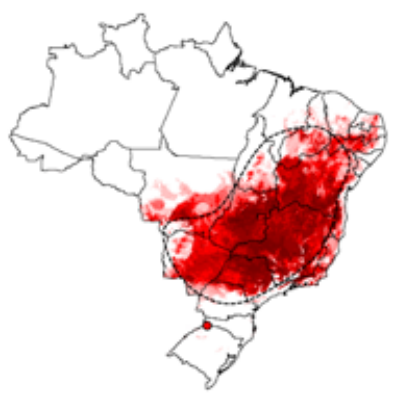

Etimologia: o epíteto específico sordida vem do latim "sordidus, sordida" que significa sujo.

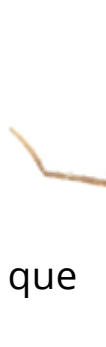

Sinônimos: Conorhinus sordidus Stål, 1859; Eutriatoma sordida Pinto, 1931.

Características gerais: comprimento total dos machos de 14 a $19 \mathrm{~mm}$, das fêmeas de 15 a $20 \mathrm{~mm}$. Coloração geral do castanho claro ao castanho escuro com manchas amareladas claras na cabeça, pescoço, pronoto, escutelo, hemiélitro, pernas e conexivo; em alguns espécimes também na região ventral do abdômen. Cabeça rugosa e granulosa, de cor castanho com região anteocular amarelada; menos que duas vezes mais longa que larga ao nível dos olhos (1: 0,55-0,60) e tão ou ligeiramente mais longa que o pronoto (1:0,85-1,0). Região ante-ocular 3 vezes mais longa que a pós-ocular (1:0,3-0,35). Proporção entre a largura de um olho e a região interocular =1: 0,75-1,20. Tubérculos anteníferos situados ligeiramente além da metade da região anteocular. Primeiro artículo antenal aproximando-se mas não ultrapassando o ápice do clípeo. Proporções entre os artículos antenais $=1: 2,5-3,6: 2,5-2,8: 1,7-2,0$. Rostro tão negro quanto a cabeça ou, mais frequentemente, com alguns ou todos os artículos amarelados. Proporções entre os artículos do rostro = 1:2,4-2,9:1,1-1,4. Pronoto castanho com áreas amareladas nos tubérculos e ângulos ântero-laterais. Lobo anterior com distintos tubérculos laterais e discais. Escutelo castanho escuro com processo apical amarelado. Hemiélitro de castanho escuro a claro, aproximando-se ou atingindo o ápice do VII urotergito nos machos e fêmeas. Cório amarelado com mancha triangular basal mais clara, e eventualmente mancha apical também clara. Membrana com aspecto enfumaçado e veias mais escuras que as células. Pernas com coxas e trocânteres amarelados, fêmures amarelados com anelação subapical escura, tíbias castanhas, mais escuras no ápice. Fossetas esponjosas presentes nas tíbias anteriores e médias dos machos, ausentes nas fêmeas. Conexivo com manchas negras transversais incluindo a sutura intersegmental e desenho variado. Para descrição completa veja Lent \& Wygodzinsky (1979).

Material tipo: de T. sordida, depositado no Zoologisches Museum, Berlim, Alemanha; de T. garciabesi, depositado no Museo Argentino de Ciencias Naturales, Buenos Aires, Argentina.

Habitat: ocos de árvores, pilhas de lenha, palmeiras, galinheiros, pombais e currais (Carcavallo et al. 1998)

Curiosidades: atualmente é a espécie mais frequentemente capturada no ambiente peridomiciliar no Brasil.

Distribuição: Bahia, Goiás, Maranhão, Mato Grosso, Mato Grosso do Sul, Minas Gerais, Paraná, Pernambuco, Piauí, Rio Grande do Sul, Santa Catarina, São Paulo e Tocantins.

Distribuição fora do Brasil: Argentina, Bolívia, Paraguai e Uruguai. 


\section{Triatoma tibiamaculata}

\section{(Pinto, 1926)}

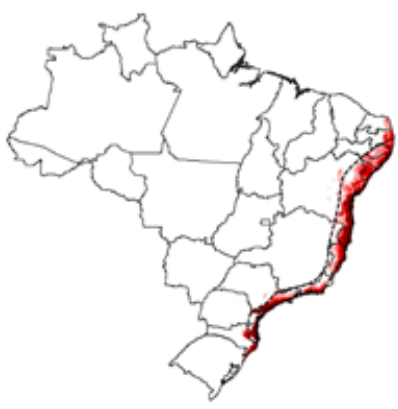

Etimologia: o epíteto específico tibiamaculata vem do latim "tíbia, tibiae" e "maculo, maculare, maculavi, maculatus" a combinação significa tíbias maculadas (manchadas), uma referência às tíbias do inseto totalmente "manchadas" de alaranjado.

Sinônimos: Eutriatoma tibiamaculata Pinto, 1926; Triatoma (Eutriatoma) tibia-maculata Lima, 1940.

Características gerais: comprimento total dos machos de 29 a 30 mm, das fêmeas de 32 a 33,5 mm. Coloração geral negra com manchas alaranjadas ou avermelhados na cabeça, pescoço, pronoto, escutelo, cório, pernas e conexivo. Cabeça negra duas vezes mais longa que larga ao nível dos olhos $(1: 0,5)$ e tão longa ou ligeiramente menor que o pronoto $(1: 1,0-1,1)$. Olhos em vista lateral ultrapassando o nível da superfície ventral, mas não atingindo o nível da superfície dorsal da cabeça. Proporção entre a largura de um olho e a região interocular = 1:1,3-1,6. Tubérculos anteníferos situados na metade da região anteocular. Primeiro artículo antenal aproximando-se muito do ápice do clípeo. Proporções entre os artículos antenais $=1: 2,7-3,0: 2,4-2,7: 1,7-1,8$. Rostro negro. Proporções entre os artículos do rostro $=1: 2,2-2,6: 0,4-0,6$. Pronoto negro com nítidas faixas avermelhadas. Lobo anterior com $1+1$ tubérculos discais e 1+1 tubérculos laterais vermelhos. Escutelo negro com

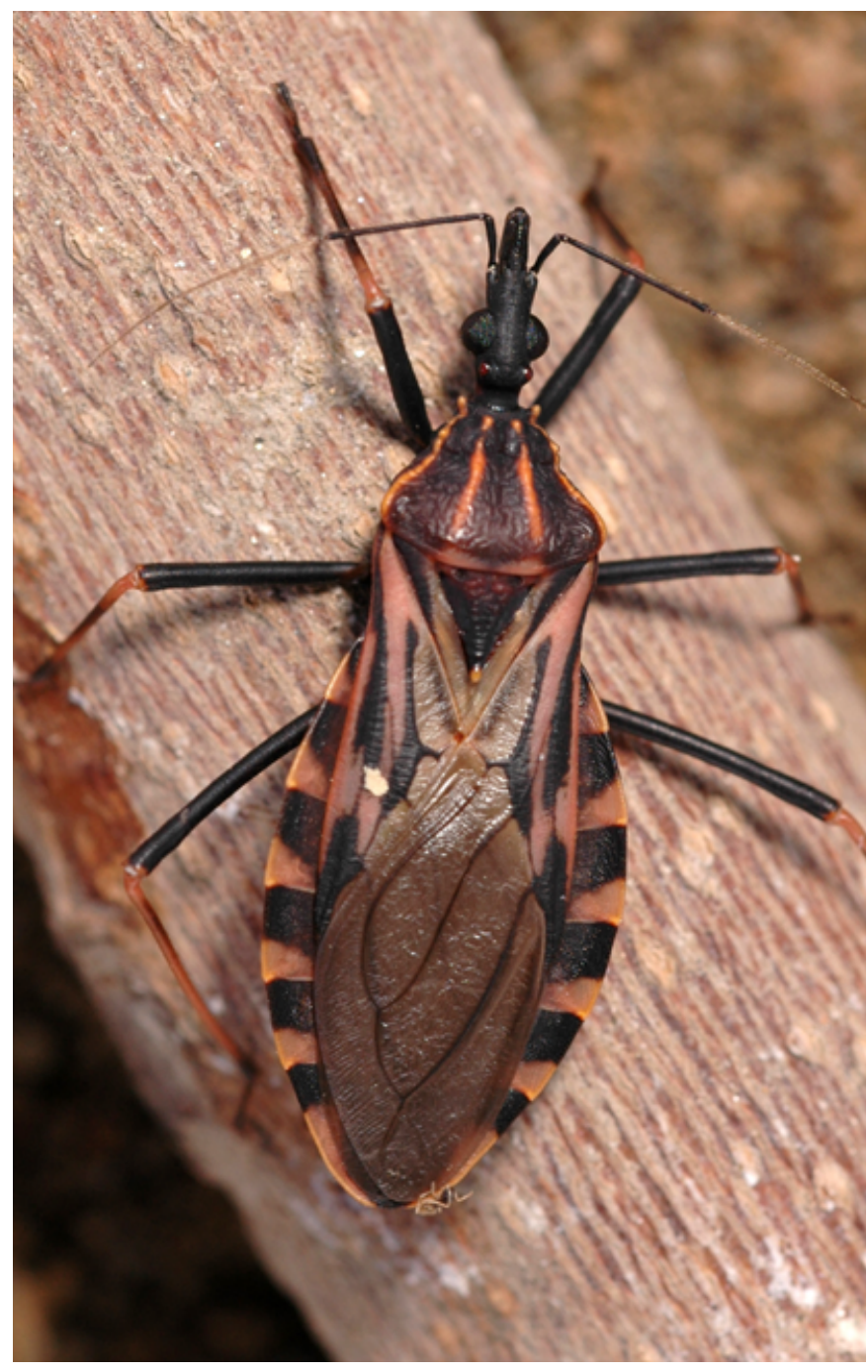
ápice avermelhado. Hemiélitro atingindo o ápice do VII urotergito nos machos e fêmeas. Cório castanho avermelhado com manchas negras ao longo de algumas veias e células. Membrana com aspecto enfumaçado e veias mais escuras que as células. Pernas negras com exceção das tíbias que são nitidamente amareladas ou alaranjadas com anelação escura no ápice. Fossetas esponjosas presentes nas tíbias anteriores e médias dos machos, presentes apenas nas tíbias anteriores das fêmeas. Conexivo com manchas transversais negras e alaranjadas ou amareladas a parte negra ocupa os dois terços anteriores de cada segmento. Para descrição completa veja Lent \& Wygodzinsky (1979).

Material tipo: depositado na Coleção Herman Lent do Instituto Oswaldo Cruz, Rio de Janeiro.

Habitat: refúgios de marsupiais e roedores, palmeiras (Carcavallo et al. 1998).

Curiosidades: Espécie silvestre da mata atlântica foi incriminada como responsável pelo surto de infecção oral de doença de Chagas no estado de Santa Catarina em 2006. O inseto teria sido triturado junto com a cana, contaminando o caldo servido.

Distribuição: Alagoas, Bahia, Espírito Santo, Minas Gerais, Pernambuco, Paraná, Rio de Janeiro, Santa Catarina, São Paulo e Sergipe. 


\section{Triatoma vandae Carcavallo, Jurberg, Rocha, Galvão, Noireau \& Lent, 2002}

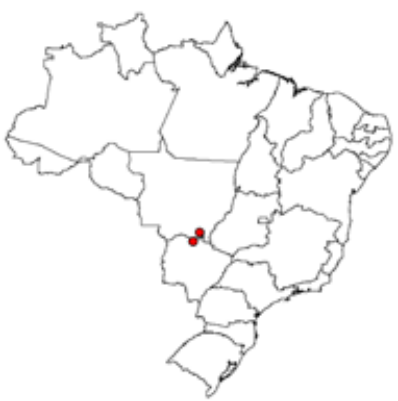

Etimologia: o epíteto específico vandae é uma homenagem a Vanda Cunha, técnica que trabalhou no insetário do Laboratório Nacional e Internacional de Referência em Taxonomia de Triatomíneos do Instituto Oswaldo Cruz

Características gerais: comprimento total dos machos de 27 a $28 \mathrm{~mm}$, das fêmeas de 29 a 30 $\mathrm{mm}$. Coloração geral castanho amarelado. Cabeça, pronoto, pleuras, prosterno e abdômen totalmente pretos. Hemélitros e parte dorsal das pernas castanhos. Áreas ventrais das pernas e conexivo amarelas. Cabeça preta, granulosa, pouco brilhante, 2,3 vezes mais longa que larga e mais longa que o pronoto (proporção $=1: 0,73$ ). Região anteocular 4,6 vezes mais longa que a pós-ocular (proporção $=1: 0,22$ ). Olhos atingindo mas não ultrapassando o limite inferior da cabeça em vista lateral e não atingindo o bordo superior. Proporção entre a largura de um olho e a região interocular $=1: 1,5$. Tubérculos anteníferos localizados um pouco adiante da metade da região anteocular. Proporção entre os artículos antenais = 1:4,3:3,1:2,5. Primeiro artículo do rostro escuro; segundo e terceiro castanhos claros amarelados. Último artículo com densa e forte pilosidade. A proporção entre os artículos do rostro é de 1:2,3:0,7. Pronoto preto, pouco brilhante. Lobo anterior pouco rugoso e pouco granuloso, colar bem marcado com ângulos ântero-laterais longos, arredondados e divergentes.Tubérculos discais e laterais ausentes. Escutelo preto, pouco brilhante com corpo robusto e depressão rugosa; processo apical do escutelo com dois terços do comprimento do corpo do escutelo. Hemélitros apenas atingindo o bordo posterior do abdômen. Clavo e cório amarelos, com exceção das veias que são escuras. Membrana castanho cinza, enfumaçada. Pernas de cor uniforme, castanho amarelado, com mancha escura no ápice dos fêmures. Fêmures anteriores e posteriores sem tubérculos, fêmures medianos com tubérculos vestigiais. Tíbias anteriores dos machos com fossetas esponjosas. Conexivo ventral amarelo sem máculas, conexivo dorsal também amarelo, quase sem máculas com exceção de uma pequena linha preta na sutura intersegmental. Para descrição completa veja Carcavallo et al. (2002).

Material tipo: depositado nas Coleções Herman Lent e Rodolfo Carcavallo do Instituto Oswaldo Cruz, Rio de Janeiro.

Habitat: peridomicílio.

Curiosidades: espécie muito similar a T. jurbergi e próxima de T. williami e T. baratai. A coloração das ninfas é marrom em $T$. vandae e marrom-avermelhado em T. jurbergi, permitindo uma fácil diferenciação entre os imaturos das duas espécies.

Distribuição: Mato Grosso e Mato Grosso do Sul. 


\section{Triatoma vitticeps (Stål, 1859)}

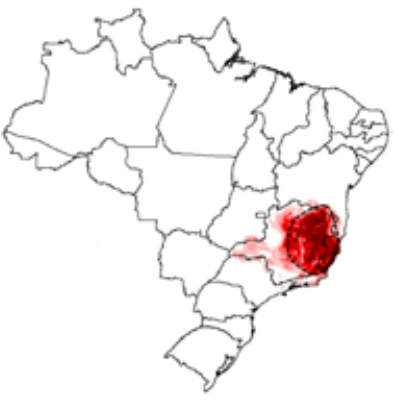

Etimologia: o epíteto específico vitticeps vem do latim "vitta" que significa faixa e "ceps" que significa cabeça, uma referência a faixa mais clara presente no dorso da cabeça do inseto.

Sinônimos: Conorhinus vitticeps Stål, 1859; Triatoma holmbergi Del Ponte, 1923; Triatoma chagasi Brumpt \& Gomes, 1941; Triatoma chagasi var. holmbergi Del Ponte, 1930; Triatoma neivai Del Ponte, 1923; Triatoma chagasi var. neivai Del Ponte, 1930

Características gerais: comprimento total dos machos de 27,5 a 33 mm, das fêmeas de 28,5 a 38 mm. Coloração geral de castanho escuro a negra com manchas alaranjadas ou avermelhadas na cabeça, pescoço, pronoto, pleura, escutelo, hemiélitro e conexivo. Cabeça castanho escuro com uma faixa dorsal castanho avermelhada indo dos ocelos até o clípeo, menos de duas vezes mais longa que larga ao nível dos olhos $(1: 0,6)$ e distintamente mais curta que o pronoto $(1: 1,1-1,2)$. Região anteocular com cerca de 3 vezes o comprimento da pós-ocular $(1: 0,35)$. Olhos em vista lateral atingindo, mas não ultrapassando, o nível da superfície ventral e não atingindo o nível da superfície dorsal da cabeça. Proporção entre a largura de um olho e a região interocular =1:1,9-2,4. Tubérculos anteníferos situados ligeiramente além da metade da região anteocu-

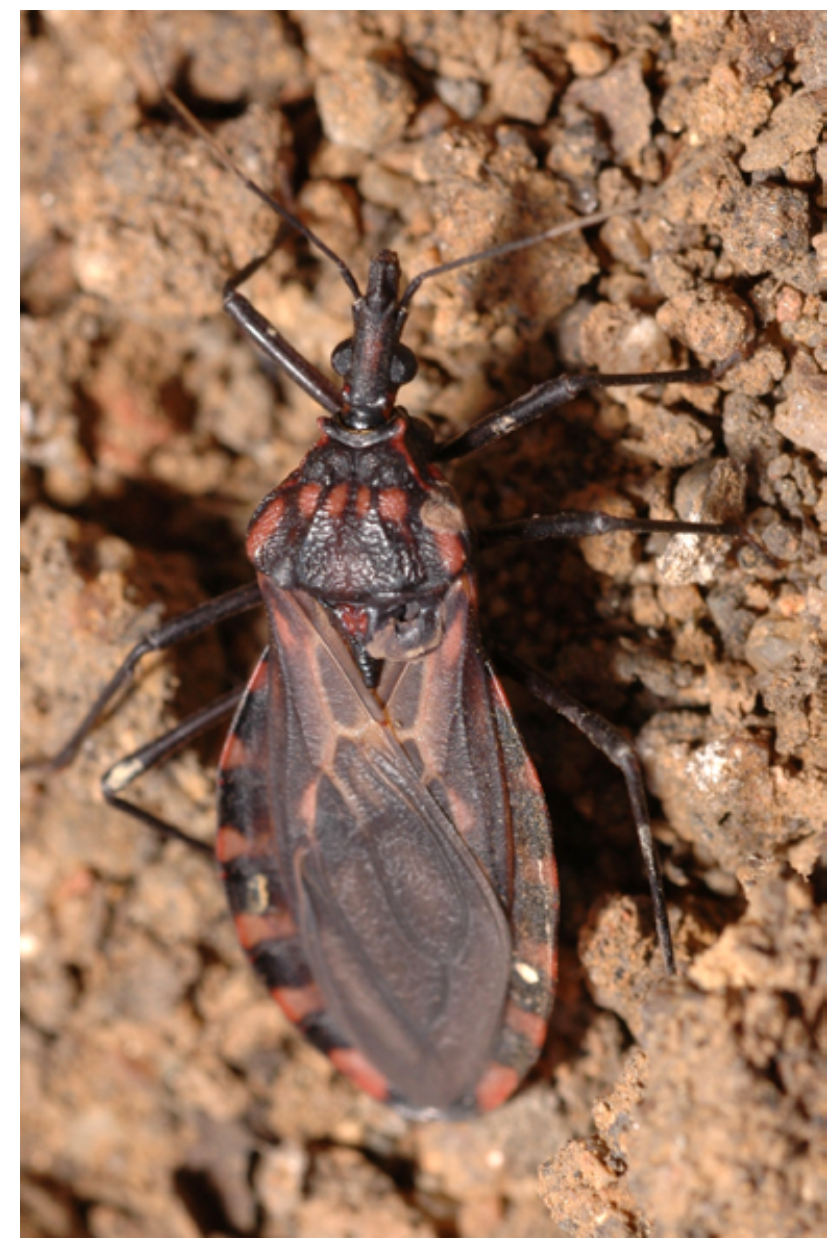
lar. Primeiro artículo antenal atingindo ou ultrapassando ligeiramente o ápice do clípeo. Proporções entre os artículos antenais = 1:3,0-3,2:2,2-2,7:1,9-2,0. Rostro tão escuro quanto a cabeça. Proporções entre os artículos do rostro $=1: 1,7-1,9: 0,8$. Pronoto castanho escuro com manchas avermelhadas. Lobo anterior com 1+1 tubérculos discais pequenos e avermelhados, em alguns espécimes com 1+1 tubérculos laterais perceptíveis. Lobo posterior com três pares de manchas avermelhadas ou alaranjadas: 1+1 na porção lateral do lobo se estendendo até os ângulos humerais; 1+1 ladeando as carenas submedianas e se estendendo por todo o comprimento do lobo posterior e 1+1 menores e mais centrais. O desenho e intensidade da cor dessas manchas pode variar de espécime para espécime. Escutelo castanho escuro com depressão central avermelhada. Hemiélitro na maioria dos espécimes atingindo o ápice do VII urotergito, castanho escuro, mais escuro no centro do cório e na base das células da membrana. Membrana castanho escuro com aspecto enfumaçado. Pernas negras. Fossetas esponjosas presentes nas tíbias anteriores e médias dos machos e fêmeas. Conexivo castanho escuro com manchas transversais alaranjadas ou amareladas menores que as áreas escuras. Para descrição completa veja Lent \& Wygodzinsky (1979).

Material tipo: de T. vitticeps depositado no Zoologisches Museum, Berlim, Alemanha; de T. chagasi na Faculte de Medecine, Paris, França e de T. holmbergi e T. neivai desconhecidos.

Habitat: refúgios de marsupiais e roedores, galinheiros, currais. Adultos frequentemente invadem casas atraídos pela luz, pequenas colônias já foram encontradas em ambiente domiciliar (Santos et al. 2005).

Distribuição: Bahia, Espírito Santo, Minas Gerais e Rio de Janeiro. 


\section{Triatoma williami Galvão,} Souza \& Lima, 1965

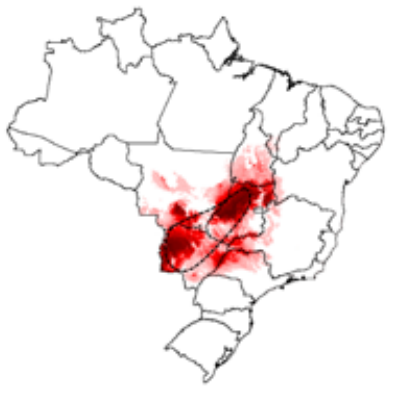

Etimologia: o epíteto específico williami é uma homenagem ao médico William Barbosa pelo empenho na criação do Instituto de Patologia Tropical do Brasil Central.

Características gerais: comprimento total dos machos de 25 a 25,5 mm, das fêmeas de 26 a $28 \mathrm{~mm}$. Coloração geral castanho escuro a negro com manchas alaranjadas no pescoço, hemiélitro e conexivo. Cabeça negra, cerca de duas vezes mais longa que larga ao nível dos olhos $(1: 0,45-0,50)$ e distintamente mais longa que o pronoto $(1: 0,8-0,9)$. Região anteocular com cerca e 4 vezes o comprimento da pós-ocular (1:0,25). Olhos em vista lateral ultrapassando o nível da superfície ventral, e aproximando-se do nível da superfície dorsal da cabeça. Proporção entre a largura de um olho e a região interocular = 1:1,25-1,45. Tubérculos anteníferos situados na metade da região anteocular. Primeiro artículo antenal não alcançando o nível do ápice do clípeo. Proporções entre os artículos antenais = 1:4,9-5,1:3,2:2. Rostro tão negro ou mais claro que a cabeça. Proporções entre os artículos do rostro =1:2,3-2,6:1,0-1,05. Pronoto totalmente negro sem tubérculos discais e laterais. Escutelo uniformemente negro. Hemiélitro atingindo o ápice do VII urotergito nos machos e fêmeas. Clavo escuro na base e ao longo da margem externa, cório castanho amarelado com veias negras, membrana castanho acinzentado. Pernas uniformemente negras, longas e esbeltas. Fossetas esponjosas presentes nas tíbias anteriores e médias dos machos, ausentes nas fêmeas. Conexivo amarelado com estreita faixa escura sobre a sutura inter-segmentar e sob pequena porção externa do conexivo. Para descrição completa veja Lent \& Wygodzinsky (1979).

Material tipo: depositado no Instituto Butantan, São Paulo.

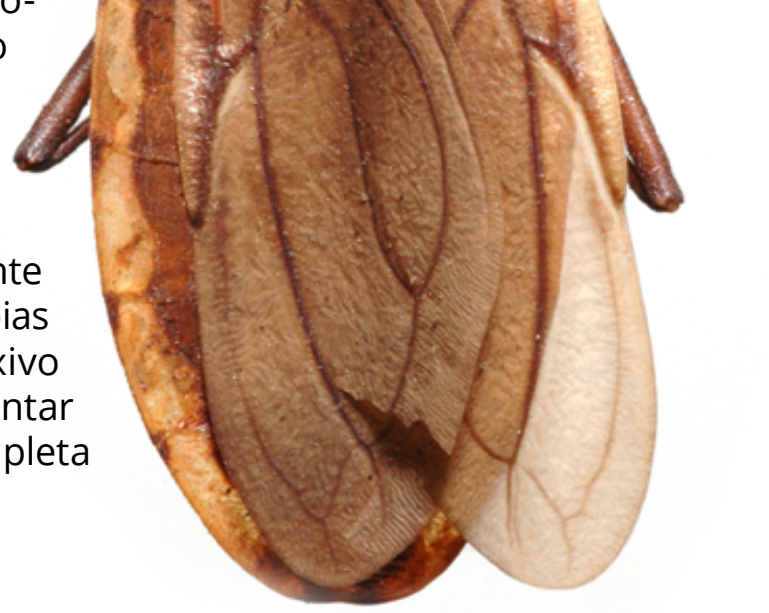

Habitat: domicílios.

Distribuição: Goiás, Mato Grosso e Mato Grosso do Sul. 


\section{Triatoma wygodzinskyi Lent, 1951}

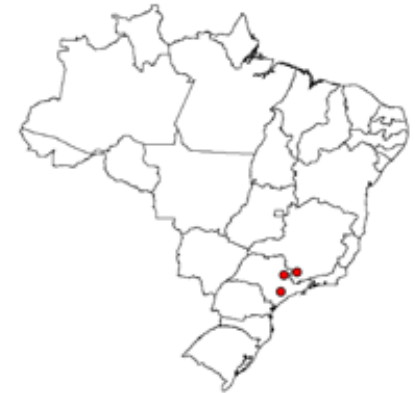

Etimologia: o epíteto específico wygodzinskyi é uma homenagem a Peter Wygodzinsky (1916-1987) hemipterologista que trabalhou no Instituto de Medicina Regional Tucumán, Argentina.

Características gerais: comprimento total dos machos de 19 a 19,5 mm, das fêmeas de 19 a $20 \mathrm{~mm}$. Coloração geral negra com manchas alaranjadas no pescoço, região humeral do pronoto, cório e conexivo. Cabeça negra, menos que duas vezes mais longa que larga ao nível dos olhos $(1: 0,6)$ e tão longa quanto. Região anteocular com cerca de 3 vezes o comprimento da pós-ocular (1:0,35). Proporção entre a largura de um olho e a região interocular $=1: 1,3-1,4$. Tubérculos anteníferos situados ligeiramente adiante da metade da região anteocular. Primeiro artículo antenal não alcançando o nível do ápice do clípeo. Proporções entre os artículos antenais $=1: 4-4: 3: 2,6$. Rostro castanho avermelhado a negro. Proporções entre os artículos do rostro $=$ $1: 2,2-2,4: 1,0$. Pronoto negro com manchas avermelhadas de conformação variada no lobo posterior. Escutelo com processo apical com cerca de três quartos do comprimento do corpo do escutelo. Hemiélitro atingindo o ápice do VII urotergito nos machos e fêmeas. Cório castanho escuro com gran-

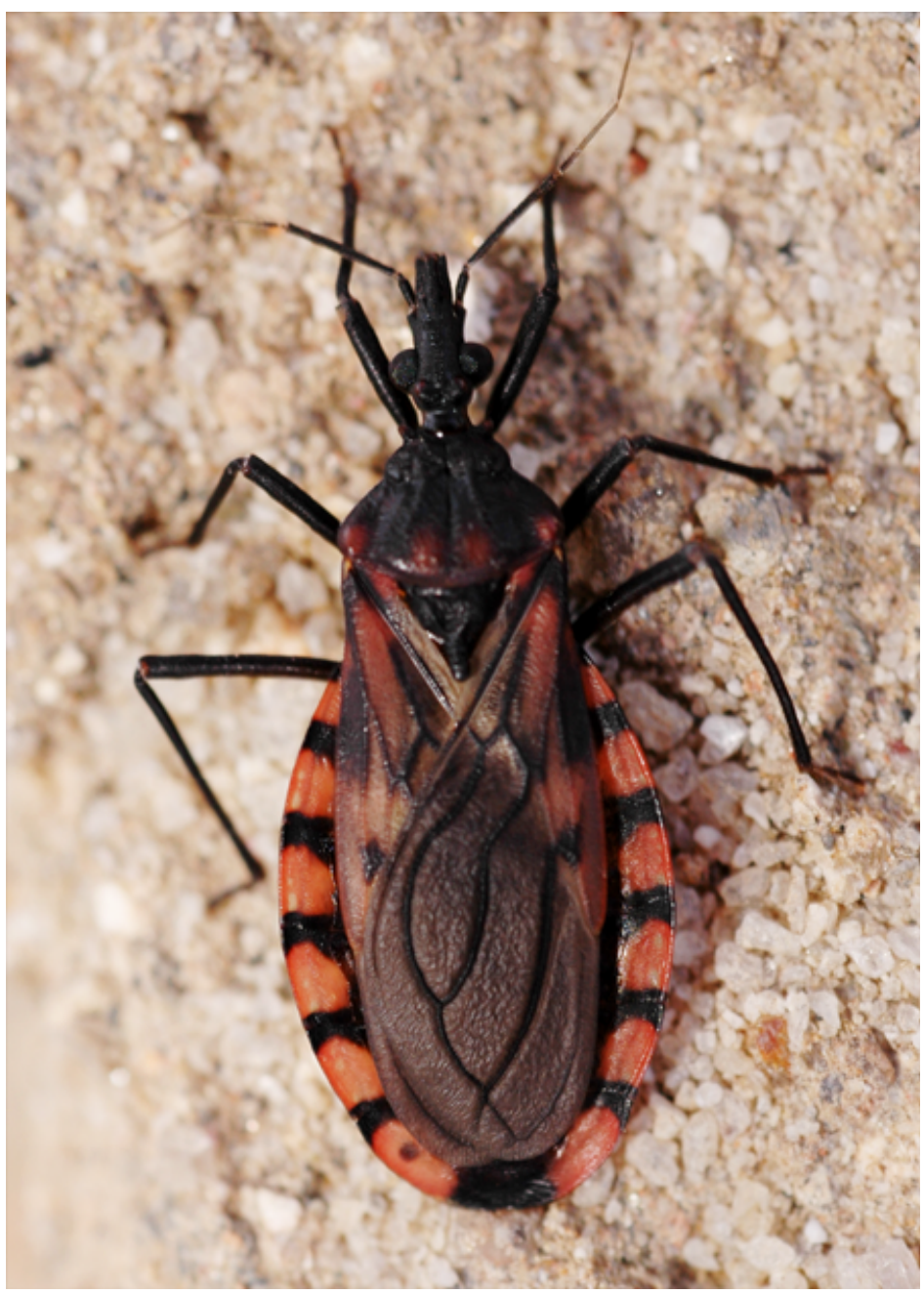
des áreas avermelhadas; base do clavo avermelhada; membrana castanho escuro com veias nitidamente mais escuras que as células. Pernas uniformemente negras, fossetas esponjosas presentes nas tíbias anteriores e médias dos machos, ausentes nas fêmeas. Conexivo com cerca de dois terços de cada segmento ocupado por faixa avermelhada, faixa escura posicionada sobre a sutura inter-segmentar. Processo do endosoma da genitália dos machos com poucos dentículos. Para descrição completa veja Lent \& Wygodzinsky (1979).

Material tipo: depositado na Coleção Herman Lent do Instituto Oswaldo Cruz, Rio de Janeiro.

Habitat: sob pedras

Curiosidades: recentes análises morfométricas publicadas por Carbajal de la Fuente et al. (2010) demonstraram que espécimes dessa espécie, provenientes de São Paulo, foram erroneamente identificados como $T$. arthurneivai gerando cerca de uma dezena de publicações dedicadas a T. arthurneivai nas quais a espécie estudada foi, de fato, T. wygodzinskyi.

Distribuição: Minas Gerais e São Paulo. 